UNIVERSIDADE DE SÃO PAULO

FACULDADE DE ECONOMIA, ADMINISTRAÇÃO E CONTABILIDADE DEPARTAMENTO DE ADMINISTRAÇÃO PROGRAMA DE PÓS-GRADUAÇÃO EM ADMINISTRAÇÃO

\title{
BASILÉIA II NO BRASIL: \\ UMA REFLEXÃO COM FOCO NA REGULAÇÃO BANCÁRIA PARA RISCO DE CRÉDITO - RESOLUÇÃO CMN 2.682/99
}

Marco Antonio Guimarães Verrone

Orientador: Prof. Dr. Wadico Waldir Bucchi 
Profa. Dra. Suely Vilela

Reitora da Universidade de São Paulo

Prof. Dr. Carlos Roberto Azzoni

Diretor da Faculdade de Economia, Administração e Contabilidade

Prof. Dr. Isak Kruglianskas

Chefe do Departamento de Administração

Prof. Dr. Lindolfo Galvão de Albuquerque

Coordenador do Programa de Pós-Graduação em Administração 


\section{MARCO ANTONIO GUIMARÃES VERRONE}

\section{BASILÉIA II NO BRASIL:}

UMA REFLEXÃO COM FOCO NA REGULAÇÃO BANCÁRIA PARA RISCO DE CRÉDITO - RESOLUÇÃO CMN 2.682/99

Dissertação apresentada ao Departamento de Administração da Faculdade de Economia, Administração e Contabilidade da Universidade de São Paulo como requisito para a obtenção do título de Mestre em Administração.

Orientador: Prof. Dr. Wadico Waldir Bucchi

\section{SÃO PAULO}




\section{FICHA CATALOGRÁFICA}

Elaborada pela Seção de Processamento Técnico do SBD/FEA/USP

Verrone, Marco Antonio Guimarães

Basiléia II no Brasil : uma reflexão com foco na regulação bancária para risco de crédito - resolução CMN 2.682/99 /

Marco Antonio Guimarães Verrone -- São Paulo, 2007.

$165 \mathrm{p}$.

Dissertação (Mestrado) - Universidade de São Paulo, 2007

Bibliografia

1. Crédito bancário 2. Crédito (risco) 3. Banco Central

I. Universidade de São Paulo. Faculdade de Economia, Administração

e Contabilidade. I. Título.

$\mathrm{CDD}-332.4$ 
Ao meu Deus.

À minha amada esposa Fabiana. Aos meus pais, Marisa e Antonio. 
Agradeço ao Prof. Dr. Wadico Waldir Bucchi, meu orientador acadêmico, pelo acompanhamento, sugestões e indicações durante o desenvolvimento da dissertação.

Expresso também gratidão ao Prof. Dr. Carlos Donizeti Macedo Maia, meu orientador técnico no Banco Central do Brasil, pela paciência e dedicação, além das sempre valiosas sugestões, opiniões e revisões ao texto.

Ao Prof. Dr. Iran Siqueira Lima por suas contribuições, especialmente no exame de qualificação.

Aos meus colegas de mestrado Kelly Kakinami, Sabrina Arruda Zerrenner e Sergio Cipriano dos Santos, pelo apoio e parceria nas disciplinas e trabalhos que realizamos em conjunto.

Faz-se indispensável um agradecimento especial ao Banco Central do Brasil, patrocinador deste mestrado, e aos muitos amigos e colegas na instituição que propiciaram as condições para a conclusão desta pesquisa.

Devo mencionar, ainda que sem poder agradecer-lhes nominalmente, os executivos entrevistados na pesquisa de campo, que compartilharam seu tempo e experiência nas longas conversas que tivemos.

A todos os familiares, amigos e colegas que, direta ou indiretamente, com seu apoio e paciência, contribuíram para possibilitar a conclusão desta dissertação.

À minha esposa, sempre ao meu lado, confiando e apoiando em todos os momentos. 
"Só sabemos com exatidão quando sabemos pouco; à medida que vamos adquirindo conhecimentos, instala-se a dúvida." Goethe 


\section{RESUMO}

O objetivo desta dissertação consiste em analisar, sob a ótica do risco de crédito, as principais questões relativas à implantação de Basiléia II no Brasil. O foco principal de pesquisa concentra-se na análise do quadro regulamentar proposto por Basiléia II comparativamente à Resolução CMN 2.682/99, principal norma que regula a mensuração do risco de crédito no Sistema Financeiro Nacional. Tal comparação tem por objetivo compreender e qualificar as diferenças, em termos dos conceitos adotados e de sua abrangência e operacionalização, entre o quadro normativo atual e o desenhado por Basiléia II. Estender essa comparação até a regulamentação anterior, a Resolução CMN 1748/90, permite caracterizar a natureza evolutiva do processo que levará à adoção de Basiléia II, evidenciando que uma ampla revisão nos conceitos relativos à mensuração do risco de crédito ocorreu no Brasil com a edição da Resolução CMN 2682/99. O presente trabalho é justificado por seu direcionamento a uma questão até o momento pouco explorada: a análise da implantação de Basiléia II no Brasil considerando o ambiente de regulação para crédito existente no país. Sem minimizar a complexidade de Basiléia II, explora-se a hipótese de que as maiores dificuldades para sua implementação no Brasil referem-se à complexidade de seus aspectos operacionais, mais do que à novidade conceitual propriamente dita, especialmente em relação aos conceitos presentes na norma brasileira para risco de crédito e sua aplicação prática a partir de sua edição, em 1999. Supre-se a carência de bibliografia discutindo Basiléia II a partir da realidade regulatória brasileira mediante a realização de um levantamento de natureza exploratória junto aos agentes de mercado envolvidos com o tema, capturando sua percepção sobre a natureza das dificuldades que vem sendo enfrentadas na preparação para Basiléia II, bem como seu entendimento quanto à evolução da regulação de crédito brasileira. 


\begin{abstract}
The main objective of this work is the analysis of the credit risk aspects related to the implementation of Basel II in Brazil. The research focus consists in the analysis of the regulatory framework proposed by Basel II compared to CMN Resolution 2.682/99, the most relevant credit risk regulation of Brazilian banking system. The purpose is to understand and qualify the differences between present regulatory environment and Basel II framework, focusing conceptual terms, involved areas and operationalization requirements. Extending such comparison to previous regulation (CMN Resolution 1748/90) characterizes the evolutive nature of Basel II adaptation process, showing that a large amount of conceptual changes concerning credit risk measurement has already happened in Brasil with CMN Resolution 2682/99. The present research can be justified by the focus on a relevant, but not properly studied aspect: the challenge of implementing Basel II in Brazil considering the regulation credit environment in the country. The explored hypothesis lies in the fact that the major difficulties for Basel II adoption in Brazil refer to the complexity of the operational aspects rather than the new concepts involved. The lack of relevant bibliography discussing Basel II based on the regulatory Brazilian environment is supplied by an exploratory survey with market agents, bringing up their perception over the nature of all the difficulties faced during the preparation to Basel II, as well as their understanding over the related aspects concerning Brazilian credit regulation.
\end{abstract}





\section{SUMÁRIO}

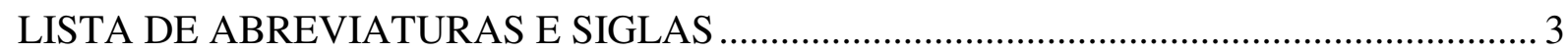

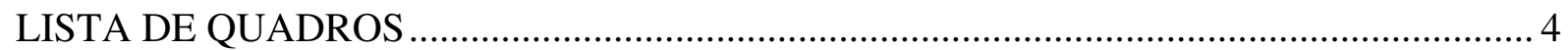

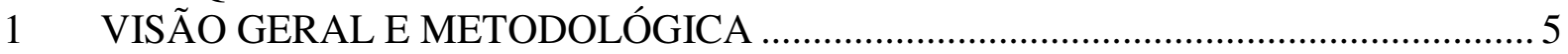

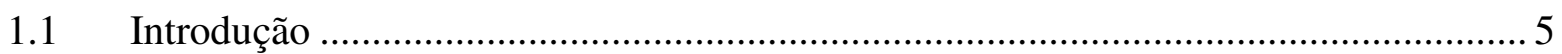

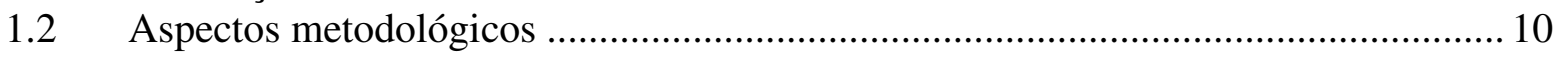

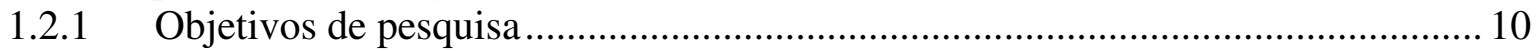

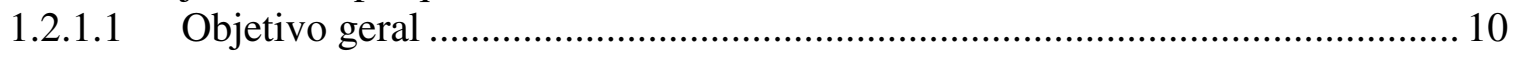

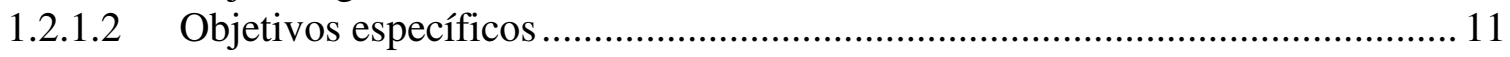

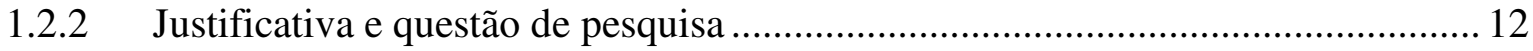

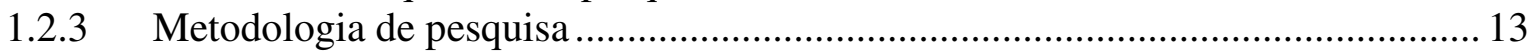

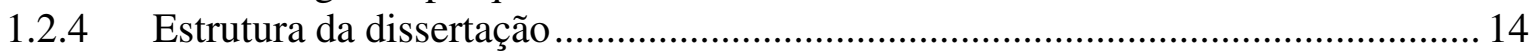

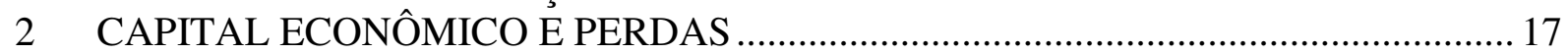

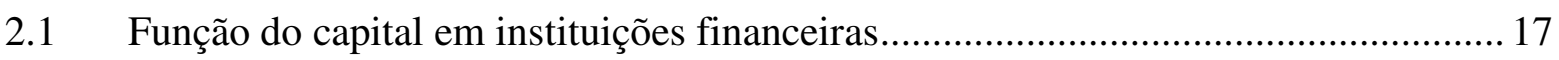

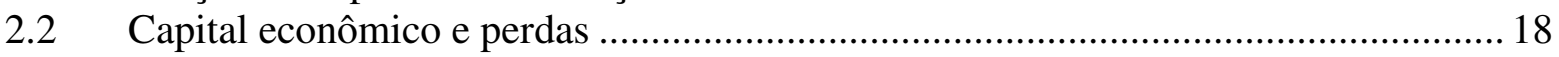

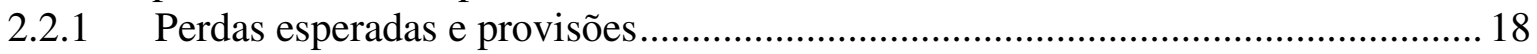

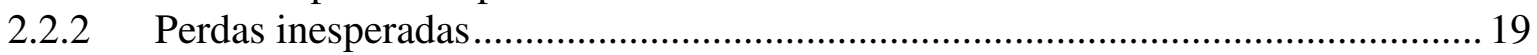

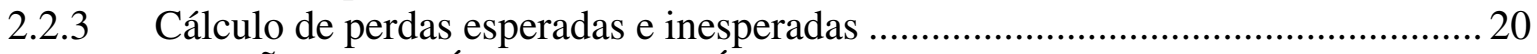

3 REGULAÇÃO BANCÁRIA E BASILÉIA I .......................................................... 23

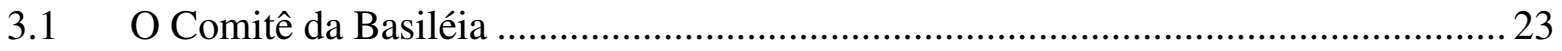

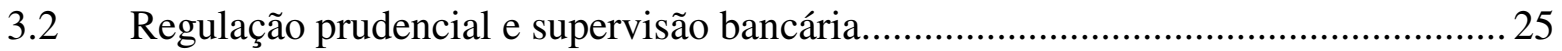

3.3 Antecedentes de Basiléia I ......................................................................................29

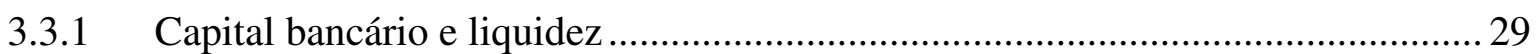

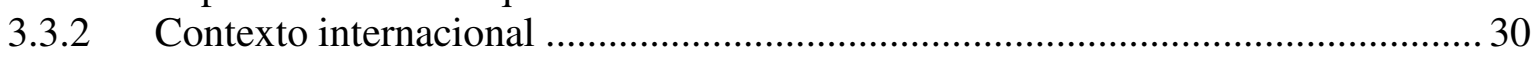

3.4 Estrutura conceitual de Basiléia I......................................................................... 32

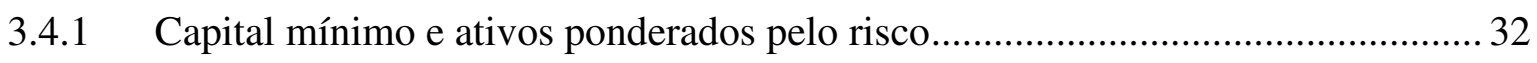

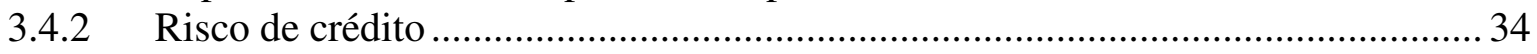

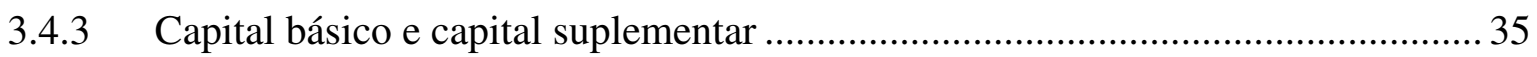

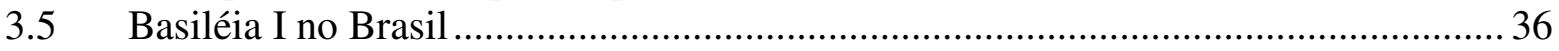

3.6 Méritos e limitações de Basiléia I ........................................................................... 39

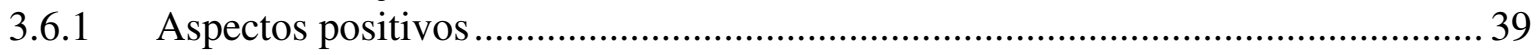

3.6.2 Deficiências de Basiléia I e a dialética da regulação............................................ 41

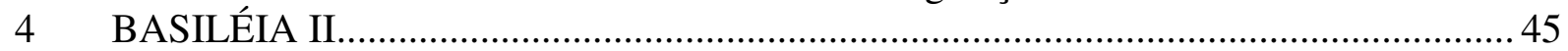

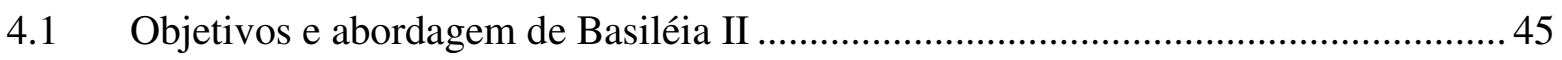

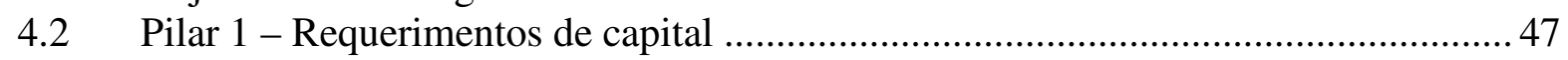

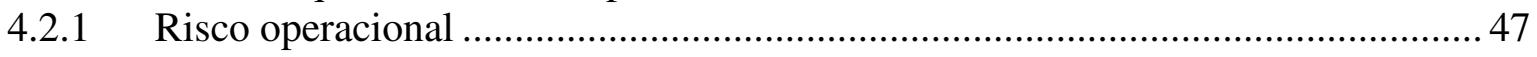

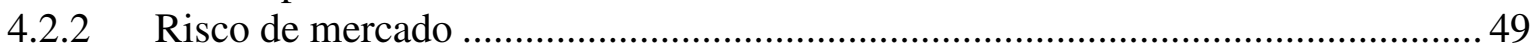

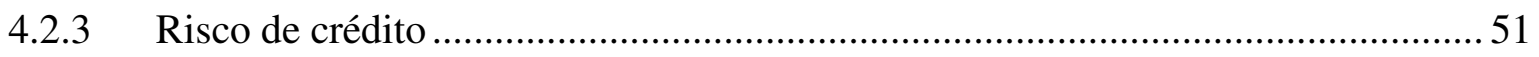

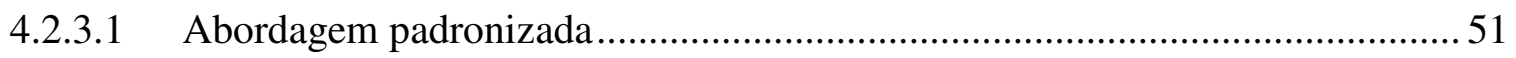

4.2.3.2 Abordagens baseadas em modelos internos - IRB ..........................................56

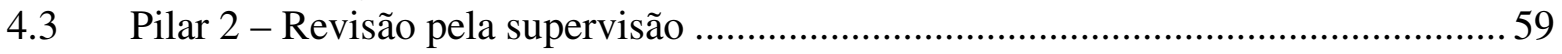

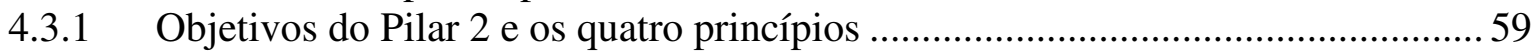

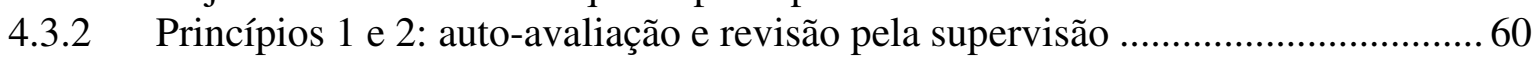

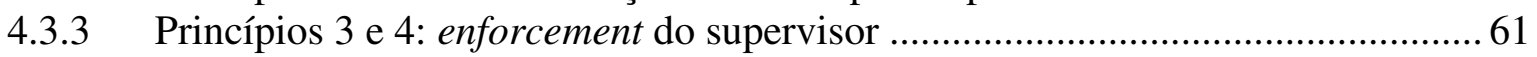

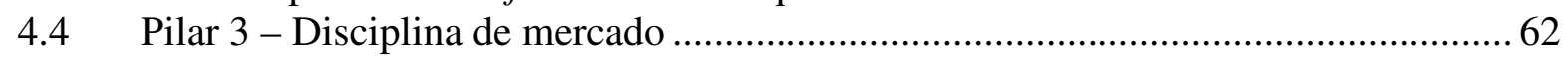

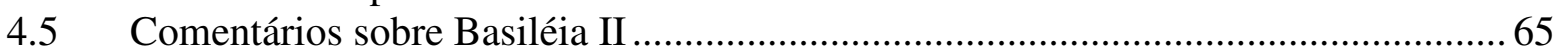

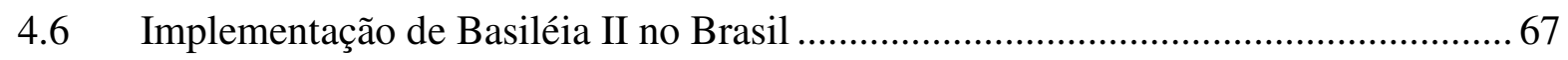

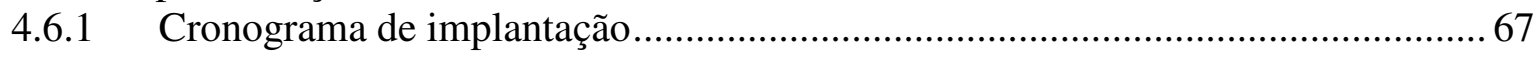




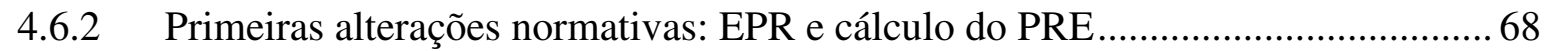

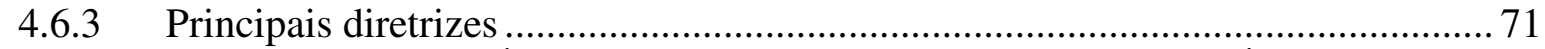

5 AMBIENTE REGULATÓRIO BRASILEIRO PARA RISCO DE CRÉDITO............ 73

5.1 Mensuração do risco de crédito: importância e regulamentação ................................. 73

5.2 Histórico recente do mercado brasileiro de crédito .................................................. 74

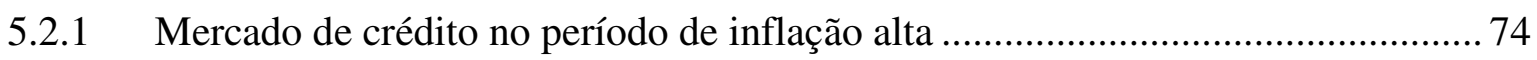

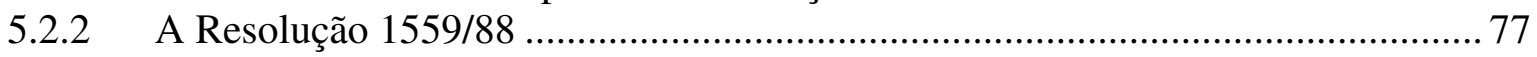

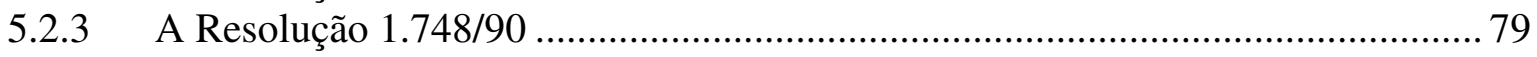

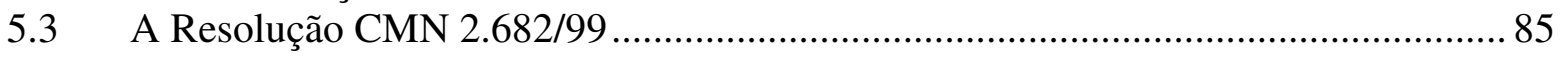

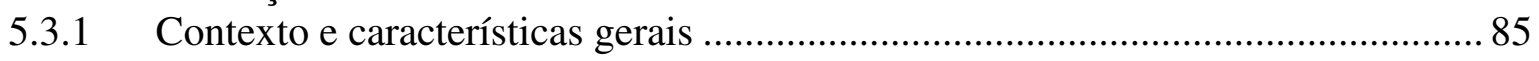

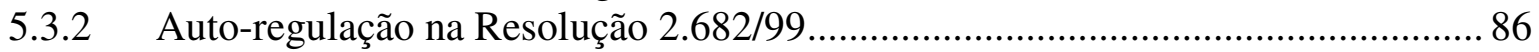

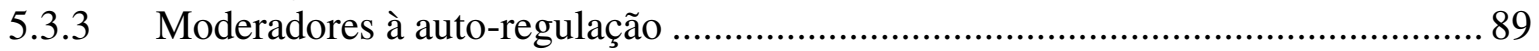

5.3.3.1 Sistemática de provisionamento e comparabilidade externa ............................. 89

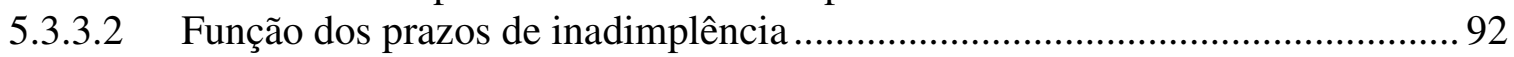

5.3.3.3 Poder discricionário da supervisão .................................................................. 94

5.3.4 Validação de modelos na Resolução 2.682 e em Basiléia II................................. 95

5.3.5 Gestão de risco de crédito, transparência e outros aspectos comuns ..................... 97

5.3.6 Da regulação tutelar à auto-regulação ................................................................. 99

5.4 Quadro comparativo das Resoluções 1.784/90 e 2.682/99 a Basiléia II................... 100

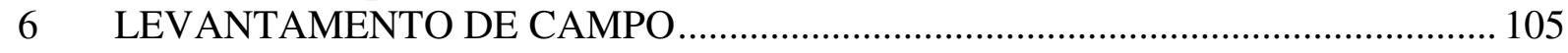

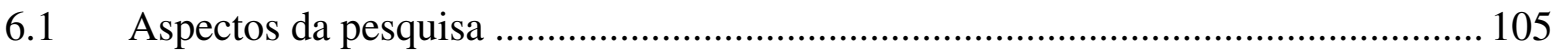

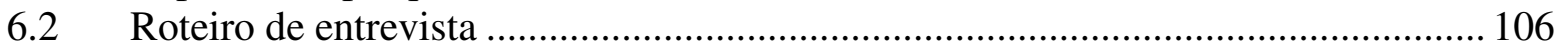

6.3 Restrições e dificuldades para implantar Basiléia II .............................................. 106

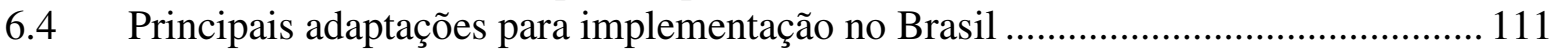

6.5 Visão sobre a Resolução CMN 2.682/99 e Basiléia II............................................. 114

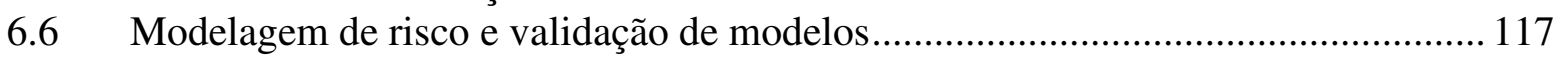

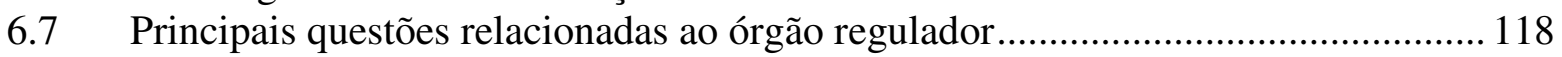

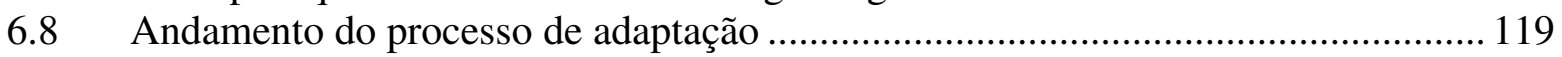

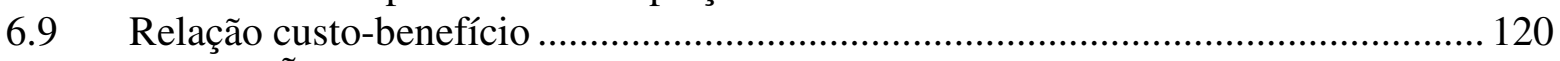

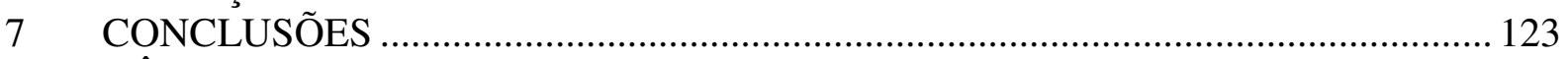

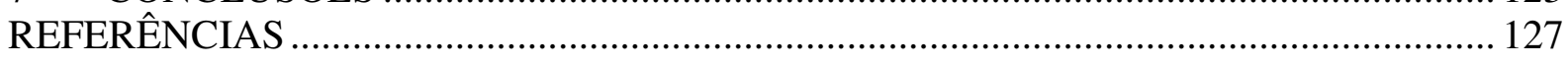

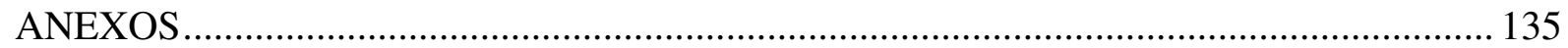




\section{LISTA DE ABREVIATURAS E SIGLAS}

ACC: Adiantamento sobre Contratos de Câmbio

APR: Ativo Ponderado pelo Risco

BACEN: Banco Central do Brasil

BCB: Banco Central do Brasil

BCBS: Basel Committee on Banking Supervision

BIS: Bank for International Settlements

CCF: Credit Conversion Factor

CL: Créditos em Liquidação

CMN: Conselho Monetário Nacional

COSIF: Plano Contábil das Instituições Financeiras

CRC: Central de Risco de Crédito

CRM: Credit Risk Mitigation

CRI: Certificado de Recebíveis Imobiliários

EAD: Exposure at Default

EPR: Exposição Ponderada pelo Risco

FCC: Fator de Conversão de Crédito

FED: Federal Reserve System

FIDC: Fundo de Investimento em Direitos Creditórios

FPR: Fator de Ponderação de Risco

IRB: Internal Ratings Based

LGD: Loss Given Default

MDB: Multilateral Development Banks

PCLD: Provisão para Créditos de Liquidação Duvidosa

PD: Probability of Default

PDD: Provisão para Devedores Duvidosos

PF: Pessoa Física

PIB: Produto Interno Bruto

PJ: Pessoa Jurídica

PL: Patrimônio Líquido

PLE: Patrimônio Líquido Exigido

PR: Patrimônio de Referência

PRE: Patrimônio de Referência Exigido

PROEF: Programa de Fortalecimento das Instituições Financeiras Federais

PROER: Programa de Estímulo à Reestruturação e ao Fortalecimento do SFN

PROES: Programa de Incentivo à Redução do Setor Público Estadual na Atividade Bancária

PSE: Public Sector Entities

SCR: Sistema de Informações de Crédito

SERASA: Centralização de Serviços dos Bancos

SFN: Sistema Financeiro Nacional

URV: Unidade Real de Valor

VaR: Value at Risk 


\section{LISTA DE QUADROS}

Quadro 1 - Fatores de ponderação por categoria de ativos................................................... 34

Quadro 2 - Basiléia I no Brasil - Fatores de ponderação ........................................................... 37

Quadro 3 - Fatores para risco operacional ...................................................................... 48

Quadro 4 - Ponderação de risco das principais classes de ativos ..............................................53

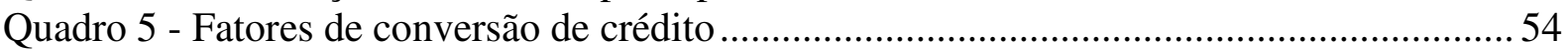

Quadro 6 - Regras de provisionamento da Resolução 1.748/90........................................... 81

Quadro 7 - Classificações e provisões da Resolução 2.682/99 ……..........................................90

Quadro 8 - Classificações em função dos prazos de atraso....................................................93

Quadro 9 - Exigências de divulgação de informações da Res. 2.682/99 ................................. 98

Quadro 10 - Análise comparativa - Resoluções CMN 1.748/90 e 2.682/99 e Basiléia II...... 101 


\section{VISÃO GERAL E METODOLÓGICA}

\subsection{Introdução}

O sistema bancário tem um papel crítico no funcionamento das economias capitalistas modernas, decorrência direta de sua atividade de intermediação financeira e da posição chave que ocupa no sistema de pagamentos. Ao realocar a liquidez financeira, por meio da captação de recursos junto aos agentes superavitários e da aplicação desses recursos junto aos agentes deficitários, os bancos facilitam tanto a poupança e o investimento quanto a produção e o consumo.

Operando majoritariamente com recursos de terceiros, assumem os riscos inerentes à intermediação financeira e, da assunção desses riscos, obtêm parte importante de sua remuneração. Nas situações em que as perdas decorrentes dos riscos assumidos se mantêm dentro de padrões históricos ${ }^{1}$, tais perdas, por serem previstas e, portanto, esperadas, são cobertas pela própria remuneração cobrada previamente junto à sua base de operações.

Há, no entanto, situações em que os prejuízos excedem os padrões históricos e, no seu conjunto, ficam além da remuneração recebida pelo risco incorrido. Nesse caso, essas perdas além do nível que era esperado, portanto perdas inesperadas, são cobertas pelo próprio capital do banco, onde o termo "capital" tem sentido amplo que inclui os recursos e reservas que possam ser mobilizados para suportar as referidas perdas.

É a existência dessa base de capital que, em adequada proporção em relação aos riscos incorridos, serve para assegurar a continuidade da instituição financeira sem depender de suporte externo, mesmo após a ocorrência de perdas significativamente acima do padrão histórico ${ }^{2}$.

\footnotetext{
${ }^{1}$ Padrões conhecidos pelas próprias instituições financeiras, mediante o acompanhamento das perdas ocorridas em suas carteiras ao longo do tempo.

${ }^{2}$ Por ser economicamente inviável deter capital suficiente para a cobertura completa de todas as possibilidades de perdas inesperadas, espera-se que o capital seja suficiente para a cobertura dos eventos de perdas não esperadas até um determinado nível, que cubra a quase totalidade desses possíveis eventos de perda.
} 
Por conseguinte, a manutenção de adequado nível de recursos próprios pelos bancos, na forma de patrimônio líquido, reservas ou outras formas de capital, tem papel fundamental em propiciar estabilidade ao sistema bancário e, portanto, ao próprio funcionamento do sistema econômico (SAUNDERS, 2000; BCBS, 1998 e 2004b) ${ }^{3}$.

Apesar de apresentar uma visão simplificada do funcionamento do sistema financeiro, a descrição acima atende ao intuito de destacar questão fundamental ao tema desta dissertação: a função e a importância do montante mínimo de capital próprio que as instituições financeiras devem manter, de moto próprio ou por exigência dos órgãos reguladores, para suportar os riscos incorridos em suas atividades.

Por se tratar de uma questão que afeta não apenas a estabilidade, mas também a competitividade dos bancos, inclusive no plano internacional, os países do G-10, reunidos no Comitê para a Supervisão Bancária da Basiléia ${ }^{4}$, acordaram e divulgaram em 1988 um padrão comum para a regulação do capital a ser exigido dos bancos que operassem em suas respectivas jurisdições.

Esse padrão de exigência de capital ficou conhecido como Acordo da Basiléia, sendo atualmente também referenciado como Basiléia I, e foi adotado não apenas pelos países membros do Comitê da Basiléia, mas pela ampla maioria das nações como mecanismo para regular seus sistemas bancários nacionais.

Basiléia I representou uma evolução em relação aos padrões regulatórios anteriores, mas algumas deficiências tornaram necessária sua revisão. Dentre essas deficiências, destaca-se especialmente que os critérios adotados eram insuficientemente sensíveis aos riscos efetivamente incorridos pelos bancos em suas operações, além de serem focalizados exclusivamente no risco de crédito. Esta última questão foi parcialmente corrigida apenas em 1996, quando os riscos de mercado passaram a ser também considerados nas exigências de capital.

\footnotetext{
${ }^{3}$ Não se pretende nesta breve introdução explorar temas exaustivamente estudados por inúmeros autores. As questões relativas ao funcionamento dos sistemas financeiros podem ser vistas em autores como, por exemplo, Saunders (2000), enquanto que aquelas relativas ao capital bancário serão aprofundadas ao longo dos próximos capítulos, sendo as fontes principais de referência BCBS $(1998 ; 2004)$.

${ }^{4}$ Basiléia: cidade na Suíça onde se localiza o BIS - Bank for International Settlements. O Comitê de Supervisão Bancária da Basiléia, que passaremos a referenciar simplesmente como Comitê da Basiléia, funciona junto ao BIS, utilizando-se inclusive das mesmas instalações físicas.
} 
O Novo Acordo de Capitais da Basiléia, também conhecido como Basiléia II $^{5}$, foi desenvolvido para suprir essas deficiências, cobrindo não somente os riscos de crédito e de mercado, mas também os riscos de natureza operacional.

Basiléia II apresenta exigências de capital mais sensíveis ao risco que o acordo anterior, bem como alternativas de aplicação com complexidades variadas, que partem desde abordagens padronizadas para medir o risco, muito semelhantes a Basiléia I, até abordagens avançadas e complexas, onde o capital regulatório é calculado a partir das próprias medidas de risco que os bancos utilizam internamente na gestão dos seus negócios.

Assim, a base conceitual de Basiléia II consiste essencialmente em aproximar o capital que se exige dos bancos para fins regulatórios do capital econômico calculado pelos próprios bancos para fins de administração de riscos, a partir de seus sistemas e modelos internos.

Esse pilar conceitual é complementado por dois outros pilares: a ação da supervisão bancária e a disciplina de mercado, que, em conjunto, têm a função de assegurar que o capital calculado pelos bancos como necessário à cobertura dos seus riscos tenha sido adequadamente estimado e tenha sido efetivamente alocado em montante superior ao mínimo necessário.

É importante registrar que Basiléia II foi desenvolvido primordialmente para economias desenvolvidas, com foco nos bancos internacionalmente ativos, conforme registrado nos próprios documentos do BCBS (2004b).

Entretanto, como esses bancos de atuação internacional detêm parte relevante de suas operações em economias emergentes, a implantação de Basiléia II tem influenciado as ações das autoridades de supervisão dessas nações, sendo futuramente adotado por muitas delas, inclusive o Brasil (BCB, 2005; BID, 2005, p.237).

Por questões concorrenciais, não apenas os bancos internacionalizados, mas também seus concorrentes de atuação local, ainda que não detenham operações internacionais relevantes,

\footnotetext{
${ }^{5}$ Será utilizado apenas o termo "Basiléia II" ao longo deste texto.
} 
tendem a buscar o aval do órgão regulador para poderem adotar modelos internos de mensuração de risco na alocação do seu nível de capital próprio.

A implementação de Basiléia II em economias emergentes enfrenta, no entanto, algumas questões importantes, notadamente o fato de que a mensuração de capital econômico por parte dos bancos, com base em modelos internos, é algo recente e, em muitos casos, ainda por implantar, enquanto que no ambiente das economias desenvolvidas o uso desses modelos é parte integrante da cultura de gestão de risco das instituições financeiras mais sofisticadas. Segundo o BID (2005, p.242):

\footnotetext{
"Embora se possa argumentar que nos países desenvolvidos o resultado dessa modificação na regulação deverá torná-la mais próxima das práticas adotadas em (algumas) grandes instituições mais sofisticadas, nos países em desenvolvimento os bancos estão defasados no que se refere a sistemas avançados de gestão de risco."
}

Apesar da estrutura prevista por Basiléia abordar três grandes grupos de riscos (crédito, mercado e operacional), cada qual passível de mensuração através de modelos próprios, o foco desta dissertação resume-se ao risco de crédito.

Ao concentrar o foco de análise nos aspectos ligados ao risco de crédito, vem à tona o fato de que uma adequada discussão da implantação de Basiléia II no Brasil demanda compreender as características do ambiente regulatório local para crédito, determinadas principalmente pela Resolução do CMN - Conselho Monetário Nacional, de número 2.682/99.

Discutir Basiléia II no Brasil sem considerar as características da regulação brasileira atual constituiria uma abordagem incompleta do tema que poderia levar a alguns equívocos em sua implantação, inclusive porque aspectos relevantes previstos por Basiléia II em relação ao crédito se fazem presentes na citada Resolução CMN 2.682/99, conforme exposto a seguir.

Em Basiléia II, a exigência de capital referente à cobertura do risco de crédito é calculada com base em três variáveis principais: a PD (probability of default - probabilidade de inadimplência), a LGD (loss given default - perda dada a inadimplência) e a EAD (exposure at default - exposição na inadimplência). 
Sem entrar no mérito, por ora, do que representam conceitualmente esses três dados de entrada, importa destacar que os mesmos são coletados e/ou estimados pelos próprios bancos para cada crédito $^{6}$, servindo como base para o cálculo dos encargos de capital a ser exigido, desde que todo o processo de mensuração e gestão do risco de crédito tenha sido avaliado e explicitamente autorizado previamente pela supervisão bancária.

No caso da norma brasileira atual, apesar da mesma destinar-se ao cálculo da constituição das provisões, um componente do capital, mas não o capital total, ela também se baseia em elementos medidos e estimados pelos próprios bancos, a partir de processos internos de avaliação de risco, conforme discutido no quinto capítulo deste texto.

A Resolução CMN 2.682/99 não estabelece, no entanto, a necessidade de aceitação prévia, por parte da supervisão bancária, dos critérios, modelos e processos utilizados pelos bancos para avaliar riscos. Por outro lado, durante a ação regular de supervisão, a aceitação, ou a não rejeição, dos resultados desses critérios, modelos e processos corresponde, na prática, à uma autorização do órgão supervisor, ainda que apenas tacitamente.

Em síntese, tanto a estrutura proposta por Basiléia II, quanto a norma atual brasileira, apresentam uma base lógica com semelhanças relevantes, onde os elementos fundamentais para o cálculo do capital (em Basiléia II) ou de parte dele (as provisões da Resolução CMN 2.682/99) são medidos e estimados pelos próprios bancos, sendo esses processos objeto de revisão por parte da supervisão bancária.

Tratam-se portanto de aspectos semelhantes em pontos fundamentais e que tornam ainda mais importante revisar e compreender o ambiente regulatório brasileiro atual para risco de crédito, a fim de contextualizar e avaliar os desafios relativos à adequada e eficaz implantação de Basiléia II no Brasil.

\footnotetext{
${ }^{6}$ Nas abordagens de Basiléia II baseadas em modelos internos de mensuração de risco de crédito estima-se, na opção mais simples, apenas a PD, enquanto nas abordagens mais complexas estimamam-se PD, LGD e EAD. A estrutura regulatória proposta por Basiléia II para risco de crédito, inclusive os conceitos de PD, LGD e EAD, será analisada detidamente no capítulo 4 , adiante.
} 


\subsection{Aspectos metodológicos}

Após abordagem preliminar do tema desta dissertação, torna-se relevante esclarecer e registrar as questões de natureza metodológica envolvidas, tratadas tendo como referência principal Lakatos e Marconi (1992) e, complementarmente, Martins (2000).

A seguir, são descritos especificamente os objetivos do presente trabalho, o problema principal de pesquisa e a metodologia de pesquisa adotada, bem como outras questões acessórias.

\subsubsection{Objetivos de pesquisa}

\subsubsection{Objetivo geral}

O objetivo geral desta dissertação consiste em analisar as principais questões relativas à implantação de Basiléia II no Brasil, relativamente ao risco de crédito. O foco do trabalho se concentra na análise do quadro regulamentar proposto por Basiléia II comparativamente à Resolução CMN 2.682/99.

Essa comparação tem como propósito compreender e qualificar a distância entre o quadro normativo atual brasileiro e aquele desenhado por Basiléia II, tanto em termos dos conceitos adotados por ambos, quanto em termos de suas respectivas abrangência e operacionalização. As comparações estendem-se até o marco regulatório anterior, a Resolução CMN 1.748/90, o que permite caracterizar a natureza evolutiva do processo de adaptação a Basiléia II e traz evidências de que parte relevante dos conceitos e práticas relativos à mensuração do risco de crédito previstos em Basiléia II foi introduzida no Brasil com a edição da Resolução CMN $2.682 / 99$. 


\subsubsection{Objetivos específicos}

Representativos das diversas e sucessivas etapas de trabalho, bem como da ordem de abordagem dos temas ao longo deste texto, os objetivos específicos desta dissertação constituem-se em:

a) Revisar os principais aspectos conceituais da regulação bancária voltada à estabilidade dos sistemas financeiros e as funções do capital bancário nessa tarefa;

b) Revisar o contexto e as características gerais de Basiléia I e de sua implantação no Brasil, bem como as causas apontadas na literatura que levaram à necessidade de sua substituição por um novo acordo de capitais;

c) Propiciar uma visão do conjunto da estrutura normativa proposta por Basiléia II e uma abordagem detalhada dos aspectos relacionados ao risco de crédito;

d) Analisar a evolução do quadro regulatório brasileiro, dado pelas Resoluções CMN $1.748 / 90$ e 2.682/99, bem como dos conceitos e requisitos presentes nessas normas para mensuração de risco de crédito, comparando-os com aqueles previstos por Basiléia II;

e) Compreender e discutir, com base na comparação acima referida, em quais aspectos a norma atual para risco de crédito atende ou aproxima-se conceitualmente do quadro desenhado por Basiléia II e em quais aspectos existe necessidade de evolução conceitual significativa;

f) Levantar, mediante entrevistas junto a executivos do mercado financeiro nacional envolvidos com a implantação de Basiléia II, a percepção desses agentes quanto ao quadro normativo atual para crédito, a evolução desse quadro em perspectiva histórica e as adaptações a serem realizadas para adequar Basiléia II às características do mercado brasileiro, bem como acerca dos desafios, percorridos e a percorrer, para adoção dessa versão do acordo de capitais no Brasil;

g) Contribuir, por meio das conclusões apresentadas e das discussões suscitadas pelas entrevistas, com o processo brasileiro de adaptação regulatória e das práticas de supervisão a Basiléia II, no que tange ao risco de crédito. 


\subsubsection{Justificativa e questão de pesquisa}

A principal justificativa para este trabalho consiste em trazer à discussão aspecto até o momento pouco explorado dentro do tema de Basiléia II. Mais especificamente, trata-se da discussão do processo de implantação de Basiléia II no Brasil considerando o ambiente de regulação e supervisão bancárias para crédito pré-existentes no país.

A escassez de literatura abordando a questão pela ótica normativa, bem como a necessidade de revisão da evolução histórica da regulação de crédito no país, motivam o presente trabalho e permitem uma abordagem original, propiciando registro do passado recente dos mercados nacionais de crédito.

Decorrente do enfoque adotado, bem como dos fatos, problemas e semelhanças abordados na introdução, surge a questão de pesquisa que norteia esta dissertação: deveria a implantação de Basiléia II no Brasil ser tratada como uma transformação ampla no mercado de crédito, um efetivo ponto de ruptura com as práticas e regulamentos que lhe antecedem, demandando a construção de práticas de mercado e marcos regulatórios inteiramente novos? Ou esse processo poderia ser mais bem compreendido e implementado se considerado como sendo uma nova etapa de um longo processo evolutivo, a continuidade natural de uma série de mudanças que vem se dando tanto nas normas, quanto nas práticas do mercado nacional ao longo do tempo?

Sem minimizar a complexidade de implantação de Basiléia II, são apresentadas evidências para a hipótese de que as dificuldades para adoção dessa nova versão do acordo de capitais no Brasil devem-se na maior parte aos seus aspectos operacionais, pois parte dos conceitos previstos por Basiléia II foi introduzida na regulamentação e nas práticas de mercado brasileiras a partir de 1999, com a edição da Resolução CMN 2.682/99.

Este trabalho busca apresentar e consolidar que aspectos encontram-se incorporados às práticas de mercado e regulação e que aspectos representam lacunas a serem preenchidas.

Ressalte-se o aspecto interdisciplinar desta pesquisa, pois o estudo da regulação de mercados financeiros e da mensuração do risco de crédito abrange aspectos relacionados à 
Administração Financeira, à Contabilidade e à Economia, trazendo contribuições a essas três áreas das ciências sociais aplicadas.

\subsubsection{Metodologia de pesquisa}

Para responder à questão de pesquisa, a metodologia adotada compreende a elaboração de um estudo de caso histórico e analítico sobre o quadro regulatório brasileiro para risco de crédito aliado à realização de um levantamento qualitativo (survey).

Dessa forma, são conjugadas duas frentes de pesquisa mutuamente complementares: a análise das características de Basiléia II para risco de crédito comparativamente ao quadro normativo brasileiro e a execução de um levantamento qualitativo junto a uma amostra dos principais agentes do mercado envolvidos com o assunto. Em conjunto, essas duas frentes propiciam os elementos para uma reflexão sobre a implantação de Basiléia II no Brasil.

Na primeira frente de pesquisa, partindo de uma revisão das características de Basiléia I e II e da história recente do mercado de crédito brasileiro, são analisados a norma e o contexto do mercado nacional, colocando em perspectiva os principais pontos levantados frente à estrutura proposta por Basiléia II. Complementarmente, é apresentado um quadro comparativo analítico a fim de sistematizar a análise da evolução da norma brasileira de modo comparado ao quadro desenhado pelo futuro acordo de capitais.

Esse quadro comparativo contribui para compreender quais conceitos foram sendo incorporados à norma brasileira na passagem da Resolução CMN 1.748/99 para a Resolução CMN 2.682/99 e, ainda, perceber quais aspectos de Basiléia II se encontram contemplados, total ou parcialmente, nos conceitos da norma atual e quais aspectos representam conceitos inovadores que devem ser incorporados ao quadro normativo.

Em complemento à análise do quadro normativo nacional, e também com o propósito de preencher a relativa lacuna bibliográfica discutindo Basiléia II a partir desse quadro normativo, são apresentados os resultados da pesquisa de campo, elaborada na modalidade de levantamento qualitativo de natureza exploratória e implementada mediante a realização de entrevistas semi-estruturadas junto a executivos do mercado bancário brasileiro de crédito, 
especificamente envolvidos com as abordagens de Basiléia II baseadas em modelos internos de avaliação de risco de crédito. Em linhas gerais, a pesquisa trata da avaliação dos entrevistados sobre:

a) A adaptação da regulamentação brasileira de crédito a Basiléia II, tratando do quadro normativo atual, da evolução desse quadro e das adaptações que devem ser feitas para adequar a nova versão do acordo de capitais às características do mercado brasileiro;

b) A natureza e grau das dificuldades, conceituais e operacionais, que vêm sendo enfrentadas na preparação para a implementação de Basiléia II no que tange ao risco de crédito;

c) Os desafios, percorridos e a percorrer, para a implantação de Basiléia II no Brasil, no que se refere à mensuração do risco de crédito.

O trabalho mostra com a metodologia adotada os aspectos presentes na literatura, como também questões em debate entre os agentes de mercado ligados ao tema, mas que carecem de registro público, uma vez que algumas dessas questões são acompanhadas pelo Banco Central em caráter sigiloso.

Uma contribuição adicional deste trabalho é trazer à discussão o aspecto relativo ao quadro normativo atual, contribuindo para criar uma reflexão sobre as condições para a implantação de Basiléia II no Brasil a partir da realidade de mercado e institucional do país, especialmente quanto às particularidades dos ambientes regulatório e operacional pré-existentes no mercado local.

\subsubsection{Estrutura da dissertação}

Esta dissertação está estruturada em sete capítulos, sendo que este primeiro capítulo apresenta uma contextualização sobre o tema do trabalho e as questões de natureza metodológica da pesquisa.

O capítulo 2 discute a natureza e a função do capital econômico em instituições financeiras, bem como os conceitos de perdas esperadas e inesperadas. O capítulo 3 revisa aspectos 
relativos à regulação e supervisão bancárias e a Basiléia I, desde seus antecedentes, passando por suas características gerais e encerrando com os motivos que levaram à sua revisão. No capítulo 4, são descritas as características gerais de Basiléia II, bem como seus aspectos específicos relacionados ao risco de crédito.

O capítulo 5 analisa o quadro regulatório para risco de crédito no Brasil, a partir da Resolução CMN 1748/90, passando pela Resolução CMN 2.682/99 e comparando estas com o ambiente delineado por Basiléia II. O capítulo 6 trata da pesquisa de campo e da análise dos resultados obtidos.

O capítulo 7 sumariza os principais aspectos do trabalho e apresenta as conclusões da pesquisa. 


\section{CAPITAL ECONÔMICO E PERDAS}

\subsection{Função do capital em instituições financeiras}

Ao longo das últimas décadas, os níveis de capital próprio de instituições financeiras têm sido elemento fundamental no arcabouço regulatório visando à estabilidade bancária. Esse fato leva à necessidade de compreender e explorar mais detidamente alguns aspectos sobre essa questão, previamente à discussão sobre os acordos de capital da Basiléia e sobre a Resolução CMN 2.682/99.

Segundo Saunders (2000, p.391), o capital é a forma principal de proteção contra o risco de insolvência e falência em instituições financeiras, tendo portanto a função de protegê-las dos riscos incorridos em suas operações. Também Koch e MacDonald (2000, p.60, apud GARCIA,2002, p.22), ao tratar das funções do capital, cita como uma de suas missões básicas a absorção de perdas extraordinárias para fins de preservação da liquidez.

No que se refere às instituições financeiras, a função do capital é especialmente relevante, pois eventuais perdas sofridas devem consumir primeiramente os recursos próprios da instituição, não apenas por conta da responsabilidade legal dos acionistas, mas principalmente por ser a preservação da liquidez aspecto fundamental para a sobrevivência de bancos. Tratase de questão tão crítica que, mesmo solvente e saudável, uma instituição financeira pode ser levada à quebra por falta de liquidez junto aos seus depositantes. ${ }^{7}$

É por essa razão que, ao estabelecer normas sobre o montante de capital próprio a ser mantido por instituições financeiras, os reguladores criam uma proteção aos depositantes e demais investidores externos nessas entidades. Adicionalmente, ao determinar que o quantitativo de capital próprio seja proporcional aos riscos incorridos, essa proteção ganha em eficácia, uma vez que, a uma maior probabilidade de perda de ativos, corresponde uma maior proporção de capital próprio que pode vir a ser consumido no caso dessas perdas virem a se realizar.

\footnotetext{
${ }^{7}$ Justamente por essa razão, o foco inicial dos reguladores ao buscar a estabilidade financeira foi procurar assegurar a liquidez das instituições financeiras, como será visto adiante.
} 
Essa proteção é extensiva ao próprio sistema bancário, pois:

\footnotetext{
“A necessidade de capital próprio em uma instituição financeira está intimamente relacionada [...] à manutenção da estabilidade do Sistema Financeiro através da diminuição do risco de quebra de instituições financeiras." (GARCIA, 2002, p.27)
}

\subsection{Capital econômico e perdas}

Ainda sobre o capital, cabe observar que sua definição não é única, ao contrário, pode variar se a ótica for contábil, econômica ou regulatória. Se, por um lado, a diferença entre o valor dos ativos e o valor dos passivos resulta no que se conhece por patrimônio líquido contábil, por outro lado a forma de avaliação do valor desses ativos e passivos, a partir do custo histórico ou do valor de mercado, acaba por levar a diferenças entre as formas de mensuração do capital.

Além disso, Saunders (2000, p.393) lembra que os reguladores, ao normatizarem sobre o capital a ser mantido pelas instituições financeiras, acabam necessitando adotar definições que não se encaixam plenamente nas definições contábeis, o que decorre do fato de que, para fins regulatórios, parte dos ativos e passivos normalmente são avaliados a custo histórico e parte a preços de mercado e, ainda, que alguns passivos também podem ser considerados como capital. $^{8}$

Ao tratar do capital econômico, Prado, Bastos e Duarte Jr. (2001, p.5), apresentam a seguinte definição:

“[...] o capital econômico da instituição pode ser definido como o montante de patrimônio líquido necessário para cobrir qualquer valor de perda entre as perdas esperadas e a taxa de insolvência observada".

\subsubsection{Perdas esperadas e provisões}

Segundo esses autores, as perdas esperadas podem ser entendidas como o impacto financeiro antecipado de perdas com crédito, sendo portanto o próprio custo previsível de conceder

\footnotetext{
${ }^{8}$ Ver Capital Nível I e Capital Nível II, adiante.
} 
crédito. Desse modo, as perdas esperadas devem ser cobertas pela provisão para devedores duvidosos. (FREIRE FILHO, 2002, p.45)

Também Marion (1998, p.340) suporta esse entendimento das provisões para crédito, ao destacar que um dos tipos de provisões refere-se às reduções nos ativos, decorrentes de expectativas de perdas. Segundo o autor, expectativas de perdas desse tipo são exemplificadas pelas provisões para créditos de liquidação duvidosa.

Portanto, as perdas esperadas, por serem previsíveis, podem ter seus custos diretamente alocados a cada negócio realizado. No caso de operações de crédito, isso significa que, ao contratar créditos com um conjunto de tomadores de recursos, a taxa de juros cobrada embute a perda esperada para aquele grupo, tendo as provisões o efeito de reduzir os ativos na proporção que se espera será a perda dessa rentabilidade.

O que cobre a perda esperada medida para esses créditos são as provisões, cuja fonte de recursos para sua constituição advém do adicional de rentabilidade contratado para cobrir a

perda esperada, mas não do capital próprio. É por essa razão que a definição de Prado, Bastos e Duarte Jr. para capital econômico trata da perda que não é esperada, isto é, a diferença entre a perda esperada e perda efetiva.

\subsubsection{Perdas inesperadas}

Também Caouette, Altman e Narayanan (1999, p.263) relacionam o capital econômico às perdas inesperadas, ao afirmar que, para as instituições financeiras, o capital é um colchão contra o risco de perdas inesperadas, decorrentes da volatilidade de receitas.

Assim, as perdas inesperadas estão associadas à incerteza em relação às perdas com crédito, sendo aquelas perdas que ocorrem além do que se espera. Por não estarem cobertas pela rentabilidade prevista, portanto além das provisões, devem ser suportadas pelo capital próprio.

Entretanto, em condições normais não é economicamente viável deter capital suficiente para suportar todas as situações possíveis em que as perdas efetivas sejam superiores às perdas esperadas. 
Ainda assim, o capital econômico a ser mantido pelas instituições financeiras deve ser suficiente para suportar a quase totalidade dos possíveis eventos de perda, ficando descobertas apenas as situações muito raras, que representam, por exemplo, $1 \%$ (um porcento) dos casos. Nesse caso, tem-se que, das situações possíveis em que ocorrem perdas, em 99\% (noventa e nove porcento $)^{9}$ delas haverá cobertura pelas provisões e pelo capital econômico, conforme sintetizado no Gráfico 1 , a seguir. ${ }^{10}$

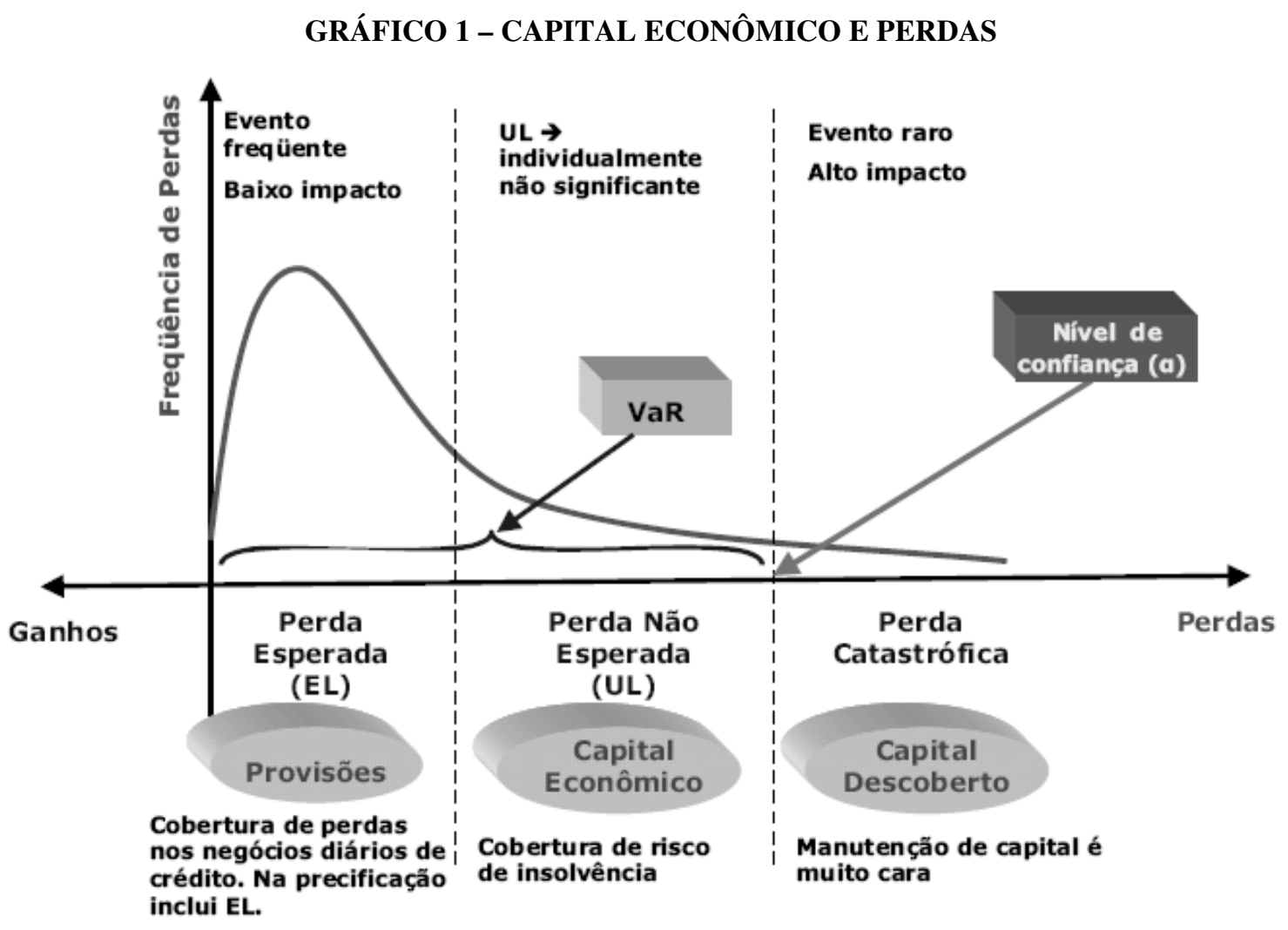

Fonte: BCB, 2006, p.21

\subsubsection{Cálculo de perdas esperadas e inesperadas}

Quanto ao cálculo propriamente dito das perdas esperadas, Antonov (2002, p.25) afirma:

\footnotetext{
${ }^{9}$ Nível de confiança.

${ }^{10}$ Conceitualmente trata-se de um modelo que faz uso do conceito de VaR - Valor em Risco, definidos por Saunders $(2000$, p.32) como sendo "[...] modelos que procuram medir a perda máxima de um dado ativo ou passivo ao longo de um período de tempo dado, em um dado nível de confiança [...]"
} 


\begin{abstract}
"A perda prevista de um devedor é igual à probabilidade de inadimplência multiplicada pela perda em caso de inadimplência. A perda prevista média de uma carteira é a média ponderada da perda provável de todos os instrumentos de dívida que a compõem, sendo que as ponderações são iguais à proporção de cada exposição individual em relação ao porte da carteira como um todo"
\end{abstract}

Antonov também esclarece os conceitos da probabilidade de inadimplência e da perda dada a inadimplência:

\footnotetext{
"Probabilidade de inadimplência [...] é a medida da probabilidade de que o devedor se torne inadimplente em relação a suas obrigações de pagamento de principal e juros [...] Perda em caso de inadimplência é a porcentagem do valor de face de um instrumento de dívida que se perde quando ocorre a inadimplência."
}

Portanto, as perdas esperadas ou EL - expected losses são obtidas a partir do produto da probabilidade de inadimplência ou $P D$ - probability of default, da perda dada a inadimplência ou LGD - loss given default e do montante de exposição no momento da inadimplência ou EAD - exposure at default, conforme segue:

$$
\mathrm{EL}=\mathrm{PD} \times \mathrm{LGD} \times \mathrm{EAD}
$$

Um exemplo para auxiliar a compreensão da equação acima é o caso de um crédito com valor de \$ 1.000.000 (um milhão de unidades monetárias), mas que apresenta uma probabilidade de inadimplência de apenas $1 \%$ (um porcento). Espera-se que esse crédito, se vier de fato a inadimplir, tenha $60 \%$ (sessenta porcento) do seu valor recuperado, portanto as perdas seriam os $40 \%$ (quarenta porcento) restantes. Nesse caso, a participação desse crédito no total de perdas esperadas da carteira do banco equivale a \$ 4.000 (quatro mil unidades monetárias), resultado do produto $\$ 1.000 .000 \times 40 \% \times 1 \%$.

Observe-se que apesar de tratar-se de um exemplo elementar, a apuração dos dados de entrada dessa equação envolve alguns processos que podem ser complexos, como por exemplo a modelagem da PD, passível de obtenção através de diversos possíveis métodos quantitativos e qualitativos, com graus diversos de sofisticação.

O cálculo da LGD além de envolver coletas de dados históricos de longo prazo para apurar a efetiva taxa de recuperação de crédito, também traz intrínseca outra questão complexa, a de definir qual taxa de desconto utilizar para trazer a valor presente o montante que se espera recuperar no futuro. 
Mesmo o cálculo da EAD pode ser complexo e trabalhoso, quando envolver linhas de crédito cujo valor contratado seja diferente do valor da exposição, como por exemplo linhas rotativas do tipo cheque especial e conta garantida.

Além das dificuldades para obtenção dos elementos que levam à perda esperada, também existem complicadores para o cálculo das perdas inesperadas ou UL - unexpected losses. Segundo Antonov:

"A perda imprevista representa a volatilidade e quantifica a diversificação da carteira. A perda imprevista de uma carteira não é de cálculo tão simples quanto a perda prevista, já que a diversificação da carteira depende da correlação entre as possíveis inadimplências dos ativos individuais compreendidos pela carteira."

Desse modo, a perda imprevista de uma carteira é uma função da perda imprevista dos instrumentos individuais de dívidas, devidamente ponderados e computadas as correlações entre esses ativos individuais, sendo suas correlações o aspecto mais complexo a ser estimado.

Finalmente, cabe destacar que os conceitos de capital econômico, perdas esperadas e inesperadas são fundamentais para a compreensão dos objetivos almejados pelos órgãos reguladores ao desenvolverem as estruturas conceituais dos acordos para regulação do capital bancário, como será visto no próximo capítulo. 


\section{REGULAÇÃO BANCÁRIA E BASILÉIA I}

\subsection{O Comitê da Basiléia}

Previamente à discussão sobre Basiléia II, faz-se necessário rever as características do acordo que o antecede, bem como da instituição em que os acordos para regulação do capital bancário têm origem, o Comitê de Supervisão Bancária da Basiléia (Basel Committee on Banking Supervision).

O Comitê da Basiléia, como é internacionalmente conhecido, se constitui de um fórum de autoridades de supervisão bancária estabelecido em 1975 pelos presidentes dos bancos centrais dos países do Grupo dos Dez, o G-10, com a finalidade de ampliar a colaboração internacional entre os órgãos responsáveis pela supervisão dos bancos (ANDREZO e LIMA, 2002, p.242; BCBS, 2004b, p.11).

Segundo o próprio Comitê, seu objetivo consiste em propiciar:

“[...] a compreensão de questões supervisórias fundamentais e o aperfeiçoamento da qualidade da supervisão bancária no mundo. Busca fazê-lo através do intercâmbio de informações relativas a questões, abordagens e técnicas sobre supervisão bancária nacional, tendo em vista a promoção de entendimentos comuns. Ocasionalmente, o Comitê utiliza tais entendimentos comuns para desenvolver diretivas e padrões supervisórios em áreas em que estes possam ser considerados desejáveis. Por essa razão, o Comitê é mais conhecido por seus padrões internacionais de adequação de capital, pelos Princípios Fundamentais para a Efetiva Supervisão Bancária e pela Concordata para Supervisão Bancária Transnacional." ${ }^{11}$ (BIS, 2007)

Atualmente, o Comitê da Basiléia é composto por "representantes seniores das autoridades de supervisão bancária e dos bancos centrais da Bélgica, Canadá, França, Alemanha, Itália, Japão, Luxemburgo, Holanda, Espanha, Suécia, Suíça, Reino Unido e Estados Unidos" (BCBS, 2004b, p.11).

\footnotetext{
11 "Its objective is to enhance understanding of key supervisory issues and improve the quality of banking supervision worldwide. It seeks to do so by exchanging information on national supervisory issues, approaches and techniques, with a view to promoting common understanding. At times, the Committee uses this common understanding to develop guidelines and supervisory standards in areas where they are considered desirable. In this regard, the Committee is best known for its international standards on capital adequacy; the Core Principles for Effective Banking Supervision; and the Concordat on cross-border banking supervision."
} 
Esses países “[...] são representados por seus bancos centrais e também pela autoridade com responsabilidade formal pela supervisão prudencial dos negócios bancários quando tal atribuição não pertencer ao banco central."12(BIS, 2007), como é o caso, por exemplo, da Inglaterra que tem como banco central (autoridade monetária) o Banco da Inglaterra e como autoridade de regulação e supervisão órgão denominado Autoridade de Serviços Financeiros (FSA - Financial Services Authority).

O Comitê da Basiléia se reúne quatro vezes por ano, geralmente no Banco de Compensações Internacionais (BIS - Bank for International Settlements $)^{13}$, na Basiléia, Suíça, onde está localizada a sede do BIS, que também provê o Secretariado do Comitê.

É importante destacar que, conforme declarado pelo próprio Comitê da Basiléia, o mesmo “[...] não possui nenhuma autoridade supranacional formal e que suas conclusões não tem força legal, nem isso foi pretendido nunca."14 (BIS, 2007).

Sua linha de atuação consiste em formular padrões supervisórios gerais, bem como linhas de ação e recomendações de melhores práticas, ficando a critério das autoridades nacionais de supervisão sua adoção, nas condições julgadas mais adequadas às características de cada nação. O Comitê declara que atua visando incentivar a convergência de abordagens e padrões de supervisão, sem no entanto buscar uma harmonização detalhada das técnicas supervisórias dos países-membro.

Apesar de tal declaração de princípios, o estabelecimento de padrões convergentes que não impliquem harmonização detalhada é tarefa complexa, sendo por vezes inviável na prática. Basiléia II, um compêndio com 826 parágrafos, mais anexos, complementado por inúmeros artigos e comunicados explicando ou esclarecendo o entendimento de aspectos específicos,

\footnotetext{
12 "Countries are represented by their central bank and also by the authority with formal responsibility for the prudential supervision of banking business where this is not the central bank."

13 Criado em 1930, o BIS, a mais antiga organização financeira internacional, visa promover a cooperação monetária e financeira entre países e "serve como banco central dos bancos centrais", agindo como:

- fórum para análise e discusão entre bancos centrais e comunidade financeira internacional;

- centro para a pesquisa econômica e monetária;

- contraparte para bancos centrais em suas transações financeiras;

- $\quad$ agente ou trustee para operações financeiras internacionais. (BIS, 2007).

14 "The Committee does not possess any formal supranational authority, and its conclusions do not, and were never intended to, have legal force"
} 
constitui um bom exemplo de como o estabelecimento de padrões comuns pode se transformar em um processo caracterizado precisamente pelo elevado nível de detalhamento.

Segundo o Comitê da Basiléia, dois princípios básicos têm norteado sua busca por fechar as lacunas existentes na cobertura supervisória internacional: “[...] que nenhum estabelecimento bancário estrangeiro possa escapar da supervisão e que esta supervisão seja exercida em bases adequadas"15 (BIS, 2007). Nesse sentido, o Comitê vem emitindo, desde sua criação, uma longa série de documentos e recomendações, destacando-se a introdução, em 1988, de um sistema para a mensuração do capital bancário, o qual ficou internacionalmente conhecido como Acordo da Basiléia e, mais recentemente, como Basiléia I.

\subsection{Regulação prudencial e supervisão bancária}

Para compreender o que levou o Comitê da Basiléia a propor um padrão internacional para a mensuração do capital mínimo a ser exigido de instituições financeiras, bem como entender as motivações para a forma adotada, torna-se relevante revisar alguns aspectos conceituais sobre a regulamentação voltada à segurança e solidez dos sistemas financeiros, denominada regulamentação prudencial.

A regulamentação prudencial visa primeiramente à proteção dos depositantes dos bancos, mas também intenta propiciar um adequado e estável funcionamento dos sistemas financeiros, ao buscar prevenir, ou ao menos mitigar, o risco de insolvência de instituições financeiras, seja em decorrência de problemas individualizados e restritos, seja em decorrência da possibilidade de que esses problemas venham a comprometer outras instituições pela quebra de confiança no sistema.

Carvalho (2005, p.126), ao tratar do risco de contágio nos sistemas financeiros e da necessidade de intervenção corretiva para a mitigação desse risco, afirma que:

\footnotetext{
15 “[...] that no foreign banking establishment should escape supervision; and that supervision should be adequate"
} 


\begin{abstract}
"No caso do sistema financeiro, esta intervenção toma duas formas: a criação de redes de segurança, para evitar choques que possam causar os problemas sistêmicos descritos, e a definição de regras de regulação e supervisão que reforcem a capacidade do sistema de evitar ou absorver choques. Esta forma de regulação será chamada de prudencial, indicando que se destina a reduzir a exposição do sistema financeiro a riscos que possam propagar-se por toda a economia."
\end{abstract}

$\mathrm{Na}$ abordagem de Saunders (2000, p.87), os mecanismos de regulação prudencial se apresentam em camadas superpostas, que se complementam na tarefa de prevenção e proteção.

Segundo esse autor, a primeira dessas camadas refere-se às exigências pelas autoridades quanto à diversificação de ativos. Dessa forma, exige-se que a instituição financeira não possa conceder, a um mesmo tomador, créditos acima de um determinado percentual sobre seus ativos ou sobre seu patrimônio líquido. Mitigam-se, nesse caso, os riscos decorrentes da concentração excessiva de ativos em um único tomador de créditos e também, a depender de como estabelecido pelo regulador, outros tipos de concentração de riscos ${ }^{16}$.

A segunda camada de proteção trata da proporção mínima de capital próprio que uma instituição financeira precisa manter para suportar o risco incorrido em suas operações, dado que, conforme discutido, eventuais perdas sofridas constituem responsabilidade legal dos acionistas da instituição e por isso devem ser suportadas pelos recursos próprios da instituição. Somente após o consumo integral desses recursos é que podem ser afetados os investidores externos, como os depositantes. Cabe destacar que essa camada de proteção tem sido cada vez mais o foco principal dos reguladores na busca pela estabilidade financeira, desde antes de Basiléia I.

A terceira camada de proteção mencionada por Saunders (2000, p.88) consiste no estabelecimento de mecanismos de seguro aos depositantes das instituições financeiras. Segundo o autor, ao proteger os investidores em instituições financeiras, em caso de quebra e esgotamento do capital próprio, tais fundos geram exigências regulatórias das instituições seguradas a fim de proteger os recursos dos próprios fundos.

Acrescente-se que mecanismos de seguro aos depositantes também servem para minimizar as possibilidades de uma corrida bancária aberta contra uma instituição que esteja em

\footnotetext{
${ }^{16}$ Concentrações de ativos detidos contra grupos econômicos, setores econômicos, grupos de interesse, regiões geográficas, entre outras possibilidades de riscos decorrentes da falta de diversificação.
} 
dificuldades momentâneas, pois, ao garantir os depósitos e aplicações, ainda que limitados a um determinado valor, reduzem a probabilidade de que momentos de pânico levem pequenos poupadores a uma retirada maciça de recursos e ocasionem a quebra de uma instituição saudável por falta momentânea de liquidez. ${ }^{17}$

A quarta e última camada de proteção refere-se ao monitoramento e à vigilância exercidos pelas autoridades reguladoras, o que envolve o acompanhamento permanente dos bancos em bases individualizadas e do sistema bancário como um todo. Esse acompanhamento é realizado conjugando, normalmente, supervisão em bases diretas e indiretas.

Lundberg (1999, p. 41) explica que a fiscalização indireta (“off site supervision”) compreende um acompanhamento com base em informações regulares encaminhadas pelas instituições financeiras ao órgão supervisor, enquanto a fiscalização de campo recebe o nome de supervisão direta (“on site supervision”).

Na supervisão indireta são analisadas as demonstrações e relatórios, contábeis ou de qualquer outra natureza, periodicamente produzidos pelas instituições, de modo a acompanhar a evolução e perspectivas da entidade supervisionada. A supervisão direta é realizada na própria instituição financeira fiscalizada, avaliando a existência e a correção do valor de ativos, passivos e outras obrigações e direitos, os processos internos de gestão, bem como os riscos incorridos pela instituição financeira e o gerenciamento dos mesmos.

Também Freitas (2000, p.411), ao tratar dos meios que permitem ao banco central reduzir as situações em que seja chamado a atuar como prestamista de última instância, ${ }^{18}$ destaca a importância da regulamentação prudencial, a qual pode ser entendida a partir de duas vertentes, cada qual derivada de suas finalidades básicas: prevenção e proteção.

Conforme Freitas:

\footnotetext{
17 Apesar de seguros aos despositantes apresentarem o benefício da mitigação de corridas bancárias, há vasta discussão teórica acerca do risco moral decorrente da garantia de depósitos.

${ }^{18}$ Atuação do banco central como emprestador de recursos a instituições financeiras em dificuldades, fornecendo liquidez em momentos de tensão financeira para impedir a eclosão de crises que abalem a confiança do público no sistema bancário.
} 
“A regulamentação prudencial envolve dois aspectos centrais: um de prevenção e outro de proteção. A regulamentação preventiva ${ }^{19}$ visa impedir a ocorrência de crise de confiança que contamine o sistema produtivo. Portanto, compreende os limites mínimos de capital, os limites de endividamento ou de alavancagem, os índices de liquidez e de risco dos ativos, as provisões contra créditos duvidosos e não pagos, os limites de concentração de empréstimos com uma só empresa, indivíduo ou país, a exigência de transparência e de fornecimento das informações necessárias para o acompanhamento e a avaliação da situação financeira e patrimonial das instituições bancárias, etc. [...] A regulamentação prudencial deve conter instrumentos de proteção ${ }^{20}$ destinados a ressarcir os interesses lesados e fornecer uma salvaguarda ao sistema quando a regulamentação preventiva falha ou não é suficiente. O sistema de seguro de depósitos é um desses instrumentos. A ação do banco central como prestamista em última instância é um outro."

Cabe destacar que "A regulamentação prudencial do sistema bancário torna-se ainda mais necessária no contexto atual de globalização financeira, que se traduz na interpenetração crescente dos sistemas financeiros nacionais.” (FREITAS, 2005, p.32). Segundo a autora, esse processo não somente modificou a natureza dos riscos incorridos pelas instituições financeiras como também os aprofundou, tornando menos eficazes as estratégias de regulação sobre o capital utilizadas tradicionalmente ao longo do século XX.

Carvalho (2005, p.127), discutindo a estratégia tradicional de regulação financeira, aponta a preocupação com o contágio como tendo sido o balizador dos esforços originais de regulamentação.

Esse autor argumenta que :

“[...] o foco da regulação prudencial, voltada para o setor bancário por ser onde o risco do sistema financeiro pode se transformar em risco global (em função dos efeitos de um colapso do sistema de pagamentos), será o banco individual ${ }^{21}$ e não as relações interbancárias que podem servir de canal de contágio de crises. Tendo em conta que a manifestação mais visível da crise sistêmica consistia na corrida bancária, não deveria surpreender que o foco original da atividade reguladora fosse justamente a liquidez dos depósitos ${ }^{22}$."

E, de fato, durante um longo período de tempo os padrões regulatórios estiveram diretamente ligados à mensuração da liquidez das instituições financeiras, o que caracterizou o foco regulatório durante um longo período do século XX.

\footnotetext{
${ }^{19}$ Grifo da autora.

${ }^{20}$ Grifo da autora.

${ }^{21}$ Grifo do autor.

${ }^{22}$ Grifo do autor.
} 


\subsection{Antecedentes de Basiléia I}

\subsubsection{Capital bancário e liquidez}

Carvalho, ao destacar que o foco dos reguladores estava na liquidez dos depósitos, auxilia a compreender porque, anteriormente a Basiléia I, os padrões de adequação de capital de bancos enfocavam medidas como índices de endividamento, estabelecendo quocientes máximos do total de depósitos sobre o capital próprio. ${ }^{23}$

Na prática, o efeito dessas medidas era que, se uma instituição desejasse aumentar seu volume de captações, seria obrigada a aumentar proporcionalmente o seu nível de capital próprio. Dessa forma, a restrição ao endividamento por meio desse tipo de índice objetivava limitar a alavancagem na captação, mantendo uma proporção razoável entre o capital próprio mantido pelas instituições financeiras e o volume de depósitos sob sua responsabilidade, assegurando liquidez a esses depósitos.

Um primeiro problema que havia nessa abordagem é apontado por Carvalho (2005, p.129):

\footnotetext{
“À medida que a regulação de liquidez focalizava mais concentradamente os depósitos à vista, ela própria acabava por servir de estímulo aos bancos para procurar outras fontes de captação, que preocupassem menos os reguladores e, com isto, estivessem sujeitas a um conjunto menor de restrições regulatórias".
}

Além disso, uma instituição financeira capta recursos não com a finalidade de entesourá-los, mas sim para gerar ativos que lhe propiciem rentabilidade superior ao custo de captação. Portanto, para fins de controle regulatório, o volume de ativos era mais representativo da alavancagem do que o montante de captações, pois estas poderiam ter sido realizadas por meios que exigissem ou não alocação de capital.

Mesmo utillizando-se o total de ativos como referência, ainda assim, restavam alguns problemas com esse tipo de forma de mensuração, pois, conforme apontado por Saunders (2000, p.402), ao se utilizar tanto os ativos totais ou as captações, deixa-se de levar em conta os diversos tipos e níveis de riscos que compõem a carteira de uma instituição. Não se

\footnotetext{
${ }^{23}$ Genericamente: Índice máximo de endividamento = Total de depósitos / Capital Próprio
} 
consideram, por exemplo, riscos de crédito, operacionais ou de variação de taxas de juros, entre outros.

De tal situação resulta que dois bancos com mesmos montantes de capital e carteira de ativos apresentam índices de capitalização semelhantes. Entretanto se a composição das carteiras de ativos forem distintas, apesar do volume ser semelhante, tais bancos podem apresentar um perfil de risco bastante distinto, a depender justamente dos riscos presentes nos seus respectivos ativos.

Outro aspecto importante destacado por Saunders está no fato de que os índices de endividamento em uso desconsideravam as atividades extrabalanço, como por exemplo as garantias prestadas, as securitizações e os derivativos, estes últimos cada vez mais em uso, não havendo assim exigência de "[...] nenhum capital para cobrir os possíveis riscos de insolvência associados a tais ativos e passivos condicionais.".

\subsubsection{Contexto internacional}

Deficiências conceituais como as acima apontadas levaram à necessidade de uma revisão na forma de regulação do capital bancário mínimo, sendo que o contexto internacional contribuiu para que essa revisão fosse adotada de maneira conjunta pelos países do G-10.

Se na Europa, a quebra do Banco Ambrosiano, em 1982, lançava questionamentos sobre a necessidade de revisarem-se as diretrizes de supervisão bancária, (TONETO e GREMAUD, 1994, apud FURTADO, 2005, p.22), foi a crise da dívida dos países latino-americanos que reforçou o processo de mudanças que levou a Basiléia I.

No início da década de oitenta, a moratória mexicana e a ameaça de moratória de outros países altamente endividados causou sérias dificuldades a bancos importantes dos Estados Unidos, obrigando o banco central local (Federal Reserve System - FED) a socorrer alguns desses bancos com um volume significativo de recursos.

Para evitar que houvesse a repetição dessa situação, por exigência do Congresso Americano, o FED apresentou um projeto de revisão normativa em que passaria a exigir das instituições 
financeiras um nível de capital mínimo que assegurasse que estas se manteriam solventes. Entretanto, houve resistência dos bancos americanos, pois esse tipo de exigência os colocaria em desvantagem frente à concorrência internacional em um momento em o processo de globalização começava a despontar de maneira mais intensa.(BCB, 2007, p.9)

Carvalho (2005, p.133) afirma que o processo de liberalização e globalização tinha acirrado a concorrência direta entre bancos americanos, europeus e japoneses, potencializando os efeitos competitivos decorrentes de eventuais diferenças no arcabouço regulatório do país de origem de cada instituição. Se os bancos americanos operavam com capital próprio relativamente elevado, seus concorrentes internacionais atuavam praticamente apenas com recursos de terceiros, o que ocasionava custos de capital mais elevados para os primeiros.

Por essas razões, o contexto de concorrência globalizada tornava inviável que a regulamentação sobre capital próprio mínimo fosse substancialmente diferente entre os países, daí que Basiléia I, segundo Carvalho (2005, p. 134) consistia “[...] principalmente na transformação da exigência de capital próprio numa norma regulatória aplicável a todos os competidores." Daí também que o acordo estivesse inicialmente voltado apenas para os bancos internacionalmente ativos.

Por um lado o acordo publicado em 1988 teve por objetivo melhorar os padrões para a alocação de capital de bancos, que passaram a ser exigidos de maneira proporcional aos riscos por estes incorridos, visando uma maior estabilidade dos sistemas bancários. Por outro, tinha o objetivo de criar padronização entre os países membros do Comitê da Basiléia, equiparando as condições de competitividade internacional independente do país onde se encontrava sediada determinada instituição financeira, bem como permitindo a comparabilidade dessas instituições.

A propósito, Carvalho (2005, p.134) argumenta que, mais do que a busca por uma atualização nos parâmetros de regulação, a razão central do acordo de 1988 seria mesmo a equiparação das condições de competição no plano internacional: 


\begin{abstract}
"A definição de uma exigência de coeficientes de capital próprio para os bancos não tinha como razão central a busca de normas prudenciais alternativas ao foco sobre liquidez, que tinha sido característico do período anterior, mas, sim, a equalização de condições competitivas entre bancos americanos, europeus e japoneses. $\mathrm{O}$ acordo resultou mais da percepção, portanto, de que a competição era injusta do que da percepção de que os sistemas até então usados de regulação prudencial tinha perdido sua eficiência."
\end{abstract}

Entretanto, aquilo que inicialmente constituía foco secundário passou a ter papel principal, pois, segundo Carvalho:

“[...] há muito tempo alimentava-se uma certa ansiedade com relação à crescente inadequação da estratégia regulatória anterior às novas condições de operação dos bancos. Por outro lado, o estabelecimento de coeficientes de capital, princípio central do acordo de 1988, parecia constituirse numa alternativa capaz de resolver os piores problemas gerados pela estratégia anterior."

Esse fato explica porque Basiléia I, apesar de ter sido criado visando um grupo restrito de bancos e países, acabou sendo adotado pela vasta maioria dos países do mundo como mecanismo para regular seus sistemas bancários nacionais, inclusive para bancos de atuação apenas local.

Carvalho afirma que não apenas os países industrializados adotaram Basiléia I “[...] de forma muito mais generalizada que o previsto, mas também o fizeram praticamente todos os outros países desenvolvidos e um grande número de países emergentes [...]”, a ponto de, no final da década de 1990, o FMI e o Banco Mundial tornarem "[...] a adesão ao acordo o elemento principal de avaliação da solidez financeira dos países membros [...]”.

Um dos principais motivos para a adoção generalizada de Basiléia I foi justamente a simplicidade de sua estrutura conceitual, conforme será visto a seguir.

\title{
3.4 Estrutura conceitual de Basiléia I
}

\subsubsection{Capital mínimo e ativos ponderados pelo risco}

Consubstanciado no documento "Convergência Internacional de Mensuração de Capital e Padrões de Capital”, de julho de 1988 e com implementação prevista para o final de 1992, para os membros do G-10, Basiléia I estabelecia padrões comuns para regular o capital 
próprio mínimo a ser exigido das instituições financeiras que operassem nas jurisdições desses países.

Em linhas gerais, Basiléia I estabeleceu que o capital mínimo necessário para cobrir os riscos e preservar a capacidade de pagamento das instituições financeiras deveria corresponder a $8 \%$ (oito porcento) da soma de seus ativos. Cada ativo, no entanto, seria computado em função de um peso variável de acordo com seu respectivo risco, compondo assim o APR - Ativo Ponderado pelo Risco.

Para cômputo do APR, os ativos foram agrupados, conforme suas características, em quatro faixas distintas, com percentuais de ponderação sobre o valor de cada ativo variando entre 0 (zero), 20 (vinte), 50 (cinquenta) e 100\% (cem porcento). Assim, a aplicação da exigência de capital de $8 \%$ do APR levaria ao cálculo do valor mínimo de capital próprio a ser exigido de cada instituição.

Um ativo, por exemplo, com risco ponderado em 50\% implicaria uma alocação de capital de 4\% do seu valor, calculada da seguinte forma: $8 \%$ (exigência de capital) multiplicado por $50 \%$ (fator de ponderação) multiplicado pelo valor do ativo. Um ativo ponderado a $100 \%$ implicaria alocação de capital de $8 \%$ do seu valor (8\% de $100 \%$ do valor do ativo). A somatória dos capitais necessários à cobertura do risco de cada ativo resultaria no capital mínimo a ser exigido da instituição financeira.

No Quadro 1, a seguir, seguem os fatores de ponderação tal como consta no documento original: 
Quadro 1 - Fatores de ponderação por categoria de ativos

\begin{tabular}{|c|c|c|}
\hline Fator & Risco & Ativos a serem ponderados \\
\hline $0 \%$ & Risco Nulo & $\begin{array}{l}\text { - Caixa e ouro } \\
\text { - Créditos contra governo central e banco central, em moeda } \\
\text { nacional } \\
\text { - Créditos contra governos desde que membros da Organização } \\
\text { para Cooperação e Desenvolvimento Econômico - OECD }\end{array}$ \\
\hline $20 \%$ & Risco Reduzido & $\begin{array}{l}\text { - Créditos contra bancos multilaterais de desenvolvimento ou } \\
\text { - } \text { garantidos por estes } \\
\text { - Créditos contra bancos sediados em países da OECD } \\
\text { prazo até um ano }\end{array}$ \\
\hline $50 \%$ & Risco Reduzido & - Financiamentos imobiliários com hipoteca residencial \\
\hline $100 \%$ & Risco Normal & $\begin{array}{l}\text { - } \text { Créditos contra o setor privado } \\
\text { - Créditos de governos não membro da OECD } \\
\text { - Créditos contra bancos sediados em países fora da OECD, com } \\
\text { - } \text { prazo superior a um ano } \\
\text { - } \quad \text { Ativéditos contra empresas comerciais do setor público }\end{array}$ \\
\hline $\begin{array}{c}0,1020 \text { ou } \\
50 \%, \text { a } \\
\text { critério } \\
\text { nacional }\end{array}$ & & $\begin{array}{l}\text { - Créditos contra entidades domésticas do setor público, exceto } \\
\text { governo central e banco central }\end{array}$ \\
\hline
\end{tabular}

Fonte: BCBS, 1988, p.17 e 18.

Além dos fatores de ponderação, dois aspectos são fundamentais na estrutura de Basiléia I: a importância do capital para cobertura dos riscos e o tipo de riscos que o acordo buscava cobrir.

\subsubsection{Risco de crédito}

O Comitê da Basiléia (BCBS, 1988, p.8) reconhecia estarem os bancos sujeitos a muitos tipos diferentes de riscos, mas para a maioria das instituições o risco mais significativo continuava a ser o risco de crédito e, que, portanto, o foco central do acordo era o risco de crédito e, 
derivadamente deste, o risco de transferência entre países, normalmente referenciado como risco soberano.

Neste ponto, torna-se oportuno formalizar a definição de crédito e risco de crédito antes de prosseguir. Sobre o tema, Santos (2000, p.15) afirma:

"Dentre as várias conceituações, uma linha de raciocínio tem predominado entre os autores: crédito refere-se à troca de um valor presente por uma promessa de reembolso futuro, não necessariamente certa, em virtude do "fator risco",

Saunders (2000, p.102) destaca também a questão dos pagamentos prometidos:

"Há risco de crédito porque os fluxos de caixa prometidos pelos títulos possuídos por instituições financeiras podem não ser pagos integralmente"

A propósito da conceituação do risco de crédito, o Comitê da Basiléia apresenta uma definição objetiva e abrangente, ao tratar não apenas dos pagamentos mas de qualquer descumprimento das condições acordadas entre as partes:

"Risco de crédito é mais simplesmente definido como o potencial que um tomador de crédito ou contraparte de uma instituição financeira venha a falhar em cumprir suas obrigações de acordo com os termos combinados ${ }^{24}$ ", (BCBS, 2000, p.1)

\subsubsection{Capital básico e capital suplementar}

Tão importante quanto o tipo de risco coberto é a própria definição do capital a ser aceito para suportar esses riscos. Por essa razão, o Comitê também apresentou uma definição de capital, dividida em duas partes: o capital básico ("core capital”) e o capital suplementar (“supplementary capital”).

Segundo o Comitê, o capital básico é constituído dos recursos permanentemente disponíveis para absorção de eventuais perdas e evitar a insolvência e perda de confiança dos depositantes. O capital suplementar, de natureza mais flexível, serviria para admitir outras formas de recursos de uma instituição financeira que tenham a função de suportar riscos. (FURTADO, 2005, p.25)

\footnotetext{
24 "Credit risk is most simply defined as the potential that a bank borrower or counterparty will fail to meet its obligations in accordance with agreed terms"
} 
Assim, o capital básico, chamado de capital de Nível I, seria composto pelo patrimônio dos acionistas e os lucros retidos, portanto o próprio patrimônio líquido da instituição. O capital suplementar, denominado capital de nível II seria composto por reservas de reavaliação, provisões gerais, instrumentos híbridos de capital e dívida ${ }^{25}$ e dívidas subordinadas.

Posteriormente, uma nova categoria de capital seria criada pelo Comitê, denominada de capital de nível III e relacionada a obrigações vinculadas de curto prazo. Essa categoria tinha a finalidade de cobrir os riscos decorrentes de posições em aberto de moedas estrangeiras, títulos, ações, commodities e derivativos.

Além da criação do capital de nível III, passou a ser exigida também a alocação de capital para a cobertura desses riscos, mediante a edição da Emenda de 1996 para Risco de Mercado, ${ }^{26}$ o qual pode ser definido, segundo Saunders (2000, p.178), "como sendo a incerteza a respeito dos lucros de uma instituição financeira, resultante de mudanças de condições de mercado, tais como o preço de um ativo, taxas de juros, volatilidade de mercado e liquidez".

\subsection{Basiléia I no Brasil}

No Brasil, Basiléia I foi adotado mediante a edição da Resolução do CMN de n 2.099, de 17.08.1994, a qual, entre outras medidas, estabeleceu para as instituições financeiras limites mínimos de patrimônio líquido a serem calculados em função dos riscos dos seus ativos.

Inicialmente foi exigido um índice de capitalização de $8 \%$ (oito porcento) em relação aos Ativos Ponderados pelo Risco - APR, em conformidade com os parâmetros internacionais. Quanto à classificação dos ativos e à atribuição dos respectivos pesos foram feitas algumas adaptações, segundo Rodrigues devido às particularidades do Sistema Financeiro Nacional SFN (1998, p.54), de modo que o capital mínimo a ser mantido pelas instituições financeiras,

\footnotetext{
${ }^{25}$ Instrumentos que combinam características de passivo e de patrimônio líquido.

${ }^{26}$ Em 1996, o Comitê da Basiléia reconhecendo a insuficiência da gama de riscos cobertos por Basiléia I, emendou o acordo original passando a exigir capital para os riscos de mercado. Na Emenda de 1996 foram estabelecidas as definições e os critérios para o tratamento desses riscos para fins de alocação de capital.
} 
denominado Patrimônio Líquido Exigido - PLE, passou a ser exigido com base na seguinte fórmula:

$$
\mathrm{PLE}=0,08 * \mathrm{APR}
$$

Os fatores de ponderação e os ativos a serem ponderados em vigência no Brasil podem ser vistos de maneira sintética no Quadro 2, a seguir:

Quadro 2 - Basiléia I no Brasil - Fatores de ponderação

\begin{tabular}{|c|c|c|}
\hline Fator & Risco & Ativos a serem ponderados \\
\hline $0 \%$ & Risco Nulo & $\begin{array}{l}\text { - } \text { Reserva bancária } \\
\text { - } \text { Caixa } \\
\text { - Operações ativas de responsabilidade ou com garantia do } \\
\text { Tesouro Nacional } \\
\text { - } \text { Depósitos no BACEN } \\
\text { - Operações compromissadas }\end{array}$ \\
\hline $20 \%$ & Risco Reduzido & $\begin{array}{l}\text { - } \quad \text { Depósitos bancários } \\
\text { - } \\
\text { - } \\
\text { Aplicações em ouro } \\
\text { Cheques enviados à compensação }\end{array}$ \\
\hline $50 \%$ & Risco Reduzido & $\begin{array}{l}\text { - Operações ativas de responsabilidade, ou com garantia de outras } \\
\text { instituições financeiras ou outras instituições autorizadas pelo } \\
\text { BACEN a funcionar (ex. aplicações em Depósitos } \\
\text { Interfinanceiros) } \\
\text { - } \text { Financiamentos imobiliários } \\
\text { - Certificados de Recebíveis Imobiliários (CRIs) }\end{array}$ \\
\hline $100 \%$ & Risco Normal & 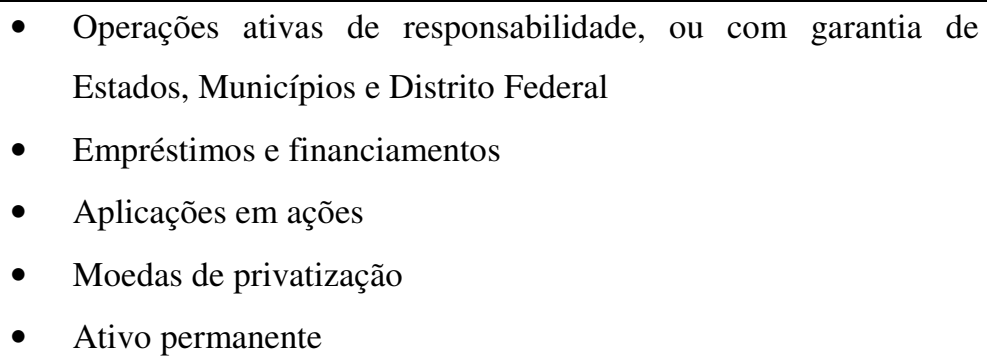 \\
\hline $300 \%$ & & $\begin{array}{l}\text { - Créditos tributários decorrentes de imposto de renda e } \\
\text { contribuição social }\end{array}$ \\
\hline
\end{tabular}

Fonte: Resolução CMN 2.099, Circulares BCB 2.916/99 e 3.031/01. 
Em junho de 1997, no contexto das crises financeiras internacionais à época, ${ }^{27}$ o CMN reforçou a necessidade de capitalização dos bancos que operam no país elevando os percentuais mínimos para $10 \%$ (dez por cento) e, em novembro daquele ano, para $11 \%$ (onze porcento) do APR, percentual que se mantém até o presente. Como lembra Rodrigues (1998, p. 58), com essas medidas a alavancagem máxima dos bancos no Brasil foi reduzida de 12,5 vezes os recursos próprios para 10 vezes e depois para 9,1 vezes os recursos próprios.

Ao longo dos anos, o CMN, acompanhando as próprias orientações do Comitê da Basiléia ao buscar suprir algumas lacunas de Basiléia I, também incorporou exigências de capital para riscos em operações de swap (1994), derivativos (1997), operações referenciadas em câmbio e ouro (1999) e riscos de mercado (2000). Cada um desses elementos conta com uma metodologia própria de cálculo, que se soma aos $11 \%$ do APR no computo do PLE:

\section{PLE $=0,11 *$ APR + Parcelas de capital para outros riscos}

O próprio conceito de PLE, com a edição da Resolução CMN 2.837 de 30 de maio de 2001, foi substituído pela criação dos conceitos de Patrimônio de Referência - PR - e Patrimônio de Referência Exigido - PRE, que servem de base para a apuração dos limites operacionais.

O PR se constitui da soma de dois níveis de capital, o capital de Nível I (capital básico) e o Capital de Nível II (capital suplementar), os quais, na forma prevista atualmente pela a Resolução CMN 3.444, de 28.02.2007, são compostos da seguinte forma: ${ }^{28}$

- Capital de Nível I: formado pelo patrimônio líquido, acrescido ou deduzido do saldo das contas de resultado credoras ou devedoras, acrescido também de eventual depósito em conta vinculada para suprir deficiência de capital, sendo deduzidos os elementos presentes no nível II e também desconsiderados alguns créditos tributários específicos $^{29}$, bem como ativos permanentes diferidos deduzidos os ágios em investimento;

\footnotetext{
${ }^{27}$ Crise asiática e crise russa.

${ }^{28}$ Os conceitos de Capital de Nível I e II foram introduzidos no Brasil mediante a Resolução CMN 2.543, de 26 de agosto de 1998.

${ }^{29}$ Nos termos dos arts. $2^{\circ}$ a $4^{\circ}$ da Resolução CMN 3.059, de 20 de dezembro de 2002.
} 
- Capital de Nível II: limitado a no máximo o valor do Nível I, é formado pelas reservas de reavaliação, reservas para contingências, reservas especiais de lucros relativas a dividendos obrigatórios não distribuídos, ações preferenciais cumulativas, ações preferenciais resgatáveis, dívidas subordinadas e instrumentos híbridos de capital e dívida, além de alguns ganhos específicos ${ }^{30}$ não realizados na marcação a mercado de títulos.

De acordo com Lundberg (1999, p.42), uma implicação importante da implementação de Basiléia I no Brasil foi ter resultado no aumento da exigência de capital e patrimônio líquido mínimos para o funcionamento das instituições financeiras, além de ter substituído a tradicional forma de acompanhamento, baseada no acompanhamento dos limites de alavancagem operacional, por uma limitação às operações ativas com base no risco ponderado destas. Apesar disso, as limitações descritas a seguir tornaram necessária a sua revisão, tanto no plano internacional quanto no Brasil.

\subsection{Méritos e limitações de Basiléia I}

\subsubsection{Aspectos positivos}

Basiléia I teve alguns méritos importantes que se destacam, tanto em relação às suas qualidades por si, quanto pelos efeitos decorrentes do acordo.

Um primeiro aspecto decorre do quanto observado por Andrezo e Lima (2002, p.242) que, ao tratar de Basiléia I, registram que este:

“[...] procurava mudar o foco das análises contábeis do passivo para o ativo e ponderar os ativos pelo risco de cada um, de modo que as instituições financeiras passariam a ter a necessidade de patrimônio líquido mínimo aferida a partir dos riscos que assumem ao emprestar, em vez de ter essa necessidade analisada em função do que tomam emprestado [...]".

A mudança de abordagem, trazendo para primeiro plano os riscos incorridos pelas instituições, ao invés do foco na liquidez dos depósitos, foi um avanço de técnica de

\footnotetext{
${ }^{30}$ Saldo dos ganhos e perdas não realizados decorrentes do ajuste ao valor de mercado dos títulos e valores mobiliários classificados na categoria "títulos disponíveis para venda" e dos instrumentos financeiros derivativos utilizados para hedge de fluxo de caixa.
} 
mensuração de adequação do capital. $\mathrm{O}$ foco da regulação voltada à estabilidade passou a mirar na origem dos potenciais problemas, pois, se uma instituição financeira deixa de pagar seus depositantes e investidores, a causa mais comum é o fato de não conseguir a realização dos seus ativos e outros direitos, seja tal situação decorrência da conversão de ativos e direitos arriscados em perdas, seja decorrência da mera impossibilidade de realizar esses ativos e direitos em prazos e condições compatíveis com a necessidade dos investidores.

Outro aspecto é a simplicidade de Basiléia I, tanto na estrutura conceitual, quanto no nível de detalhamento. "Convergência Internacional de Mensuração de Capital e Padrões de Capital" é um documento de 25 páginas, de fácil compreensão e implementação.

Além disso, não demandava um conjunto amplo de novas normas pelos reguladores, ou nos procedimentos dos regulados, tampouco exigia modificações significativas na infra-estrutura de reguladores e regulados, uma vez que a base de informações utilizada para o cálculo do índice de capitalização fazia parte do que era utilizado rotineiramente pelos bancos e supervisores: a própria contabilidade de ativos e passivos e outros direitos e obrigações.

Por conta de sua simplicidade, Basiléia I foi implantado em diversos países, gerando aumentos substanciais nos níveis de capitalização bancária, reforçando a estabilidade e solidez dos sistemas bancários nos planos local e internacional. Também propiciou competição mais equilibrada, como pretendido, ao equiparar as regras de competição entre as instituições financeiras.

Outro aspecto decorrente de Basiléia I foi o fato de ter criado uma referência simples para avaliação, de fácil compreensão e comparação pelo próprio segmento bancário, bem como por analistas e investidores, reforçando assim os mecanismos de autodisciplina que o mercado impõe aos seus participantes.

Entretanto, apesar de representar uma evolução em relação aos padrões anteriores, ainda assim Basiléia I apresentava deficiências que tornaram necessária sua revisão. 


\subsubsection{Deficiências de Basiléia I e a dialética da regulação}

Segundo Carvalho (2005, p.137), havia a percepção de que ao mesmo tempo em que:

“[...] o uso de coeficientes de capital era um avanço em relação ao foco anterior em liquidez de depósitos, disseminou-se rapidamente a percepção de que o acordo tinha sido estabelecido em termos grosseiros demais para induzirem nos bancos a seleção mais segura dos riscos a correr."

Os padrões adotados eram pouco sensíveis ao risco incorrido, uma vez que apenas quatro faixas de risco abrigavam todos os tipos de ativos possíveis. Por exemplo, as operações de crédito ao setor privado faziam parte da faixa ponderada em $100 \%$ do valor do ativo, independentemente do risco do tomador dos recursos, das garantias envolvidas, da linha de crédito e de quaisquer outras características que pudessem agravar ou mitigar o risco de crédito incorrido.

Lima também trata dessa mesma questão, ao destacar que outra deficiência importante de Basiléia I refere-se ao fato de não serem consideradas técnicas de mitigação de riscos, como colaterais, derivativos e securitização de dívidas para atenuar as exigências de capital (LIMA, 2005, p.196).

Além da baixa sensibilidade ao risco e da desconsideração de mitigadores de risco, há que se destacar ainda que o acordo de 1988 era focalizado quase que exclusivamente no risco de crédito, uma vez que somente em 1996 foi aprovada uma emenda passando considerar também o risco de mercado.

Para ilustrar a pouca abrangência dos riscos considerados, Saunders (2000, p. 99) cita os seguintes riscos como intrínsecos à atividade bancária, além dos riscos de crédito e mercado: risco de variação de taxa de juros, de operações fora de balanço, riscos tecnológicos e operacionais, risco de câmbio, risco de liquidez e risco de insolvência. A abrangência dos riscos varia conforme as definições adotadas por cada autor pesquisado, de modo que alguns desses riscos citados por Saunders são cobertos, ainda que parcialmente, nas definições adotadas pelo acordo de 1988 ou então pela Emenda de 1996.

Mas, de todos os aspectos, o mais fundamental, segundo Carvalho (2005, p.136), foi que o conceito de atividade bancária implícito em Basiléia I se tornou rapidamente obsoleto, pois a 
concepção adotada foi a do banco tradicional, captando depósitos para realizar empréstimos, enquanto que no mercado financeiro tornava-se cada vez mais comum o uso de mecanismos transferência de riscos, sem que isso necessariamente implicasse a tradição dos ativos, através de títulos, derivativos e securitizações.

Também Lima (2005) destaca como relevante na perda de eficácia de Basiléia I a disseminação de práticas de arbitragem de capital regulatório, as quais ocorrem, por exemplo, mediante a venda de ativos cujos riscos apurados pelo banco são menores dos que os estabelecidos pela regulação, de um lado, e da manutenção em carteira daqueles ativos cujos riscos efetivos são maiores que os estabelecidos normativamente, por outro lado.

Segundo Carvalho, Basiléia I inclusive acelerou o processo de modificação no perfil da atividade bancária, pois

“[...] ao punir $^{31}$ a atividade de crédito com o peso das regulações, deixando livre a operação nos mercados de papéis, o acordo estimulou os bancos a minimizarem seus custos operacionais privilegiando a participação nos processos de securitização." (CARVALHO, 2005, p.136)

Esse processo pode ser entendido como decorrência de um processo de natureza dialética, denominado por Kane (apud, CORAZZA, 2005, p.84) de dialética da regulação ${ }^{32}$, em que, segundo explica Corazza:

"[...] uma ação regulatória (tese) das autoridades gera uma reação (antítese) dos agentes financeiros, através de inovações financeiras que anulam a regulação inicial e dão início ao novo processo de re-regulação, o qual deve ser entendido como uma nova síntese".

Também Freitas (2000, p.411) descreve essa mesma dinâmica, ao lembrar que:

\footnotetext{
"Para limitar a instabilidade inerente ao sistema bancário, as autoridades procuram impor regras de prudência para o funcionamento dos bancos [...]. Todavia, se o ambiente institucional e legal permite, os bancos tentam evitar, mediante inovações financeiras, todo e qualquer controle. Os novos instrumentos e procedimentos contribuem para ampliar a complexidade das estruturas financeiras e das relações entre devedores e credores, resultando em um aumento da instabilidade do sistema. Isso exige um esforço contínuo do banco central e demais autoridades de regulamentação de aperfeiçoamento nos mecanismos de controle, supervisão e fiscalização.”.
}

\footnotetext{
${ }^{31}$ Grifo do autor.

${ }^{32}$ Grifo do autor.
} 
Em síntese, como elemento crítico para a perda de eficácia de Basiléia I, mais do que suas próprias deficiências e limitações, têm-se o fato de que a própria regulação induz ao desenvolvimento de mecanismos que irão torná-la cada vez menos eficaz, demandando a criação de novos marcos regulatórios levando, no caso presente, a Basiléia II. 


\section{BASILÉIA II}

\subsection{Objetivos e abordagem de Basiléia II}

O objetivo do Comitê da Basiléia com a edição de Basiléia II foi criar uma

“[...] estrutura que fortaleça ainda mais a solidez e a estabilidade do sistema bancário internacional e, ao mesmo tempo, mantenha consistência suficiente para que o regulamento de adequação de capital não seja fonte significativa de desigualdade competitiva entre os bancos internacionalmente ativos." (BCBS, 2004b, p.11)

Em consonância com esse objetivo, o Comitê entende que o acordo “[...] promoverá a adoção de práticas de administração de riscos mais sólidas pelo setor bancário, e considera esse um dos seus mais importantes benefícios."

Apresentado em sua versão final ${ }^{33}$ em junho de 2004, após cinco anos de discussões a partir da primeira versão divulgada para consulta pública, Basiléia II visa atualizar o acordo que o precede, suprindo suas deficiências e limitações, discutidas no capítulo anterior.

Para tanto, a nova versão do acordo de capitais busca apresentar alternativas mais sofisticadas para o cálculo do capital mínimo regulamentar, aproximando o capital exigido para fins regulatórios do capital econômico calculado pelos próprios bancos para fins de gestão de seus negócios (LIMA, 2005, p.197), bem como ampliando a gama de riscos para os quais se exige cobertura de capital.

Com implementação iniciada a partir do início de 2007 nos países membros do G-10, Basiléia II passou a exigir a alocação de capital não apenas para os riscos de crédito e de mercado, mas também para os riscos de natureza operacional, apresentando uma abordagem mais sensível ao risco efetivamente incorrido e com opções com complexidade variada e crescente.

\footnotetext{
${ }^{33} \mathrm{O}$ documento divulgado pelo BCBS intitula-se "Convergência Internacional de Mensuração de Capital e Padrões de Capital - Estrutura Revisada" e tem uma versão posterior, de junho de 2006, que inclui algumas correções mínimas e também incorpora a Emenda de 1996 para risco de mercado.
} 
Desse modo, apresenta alternativas de cálculo de capital regulamentar que variam desde abordagens padronizadas para medir o risco, muito semelhantes a Basiléia I, até abordagens avançadas e complexas, onde o capital regulatório é calculado a partir das próprias medidas de risco que os bancos utilizam internamente na gestão dos seus negócios.

A alocação de capital para suportar riscos representa a base fundamental de Basiléia II, como também o era para Basiléia I, mas desta feita com mais ênfase no uso de informações internas, conforme o próprio Comitê admite ao reconhecer a importância do uso maior de avaliações de risco fornecidas pelos sistemas internos dos bancos como dados para os cálculos de capital (BCBS, 2004b, p.12).

Ao cálculo do capital regulatório com base em métodos internos, juntam-se o processo de revisão desse processo pela autoridade de supervisão bancária e a disciplina imposta pelo mercado, formando três pilares nos quais apóia-se a nova estrutura regulatória:

- Pilar 1: Requerimentos de capital: cálculo dos requerimentos de capital para risco de crédito, risco de mercado e risco operacional, efetuado pelos próprios bancos com base em metodologias mais sensíveis ao risco que as previstas por Basiléia I;

- Pilar 2: Revisão pela supervisão: processo de autorização, revisão e validação pela supervisão bancária, assegurando a integridade das avaliações realizadas no Pilar 1;

- Pilar 3: Disciplina de mercado: disciplina imposta pelo mercado, decorrente obrigatoriedade de divulgação de informações de maneira proporcional à complexidade das metodologias utilizadas para cálculo do próprio capital.

Esses três pilares atuam de maneira mutuamente complementar, com a função de assegurar que o capital calculado e alocado pelos bancos como necessário à cobertura dos seus riscos seja efetivamente superior ao mínimo necessário para tal.

No que tange aos riscos, Basiléia II absorve a abordagem para riscos de mercado definida na Emenda de 1996, de modo que os avanços encontram-se na inclusão dos riscos operacionais e na completa revisão do tratamento para o risco de crédito. 
A descrição a seguir apresenta os aspectos do documento "Convergência Internacional de Mensuração de Capital e Padrões de Capital: estrutura revisada" relevantes aos objetivos deste trabalho.

\subsection{Pilar 1 - Requerimentos de capital}

O Pilar 1 de Basiléia II apresenta o cálculo dos requerimentos mínimos de capital dos bancos para suportar riscos operacionais, de mercado e de crédito.

Antes de tratar especificamente de cada um dos riscos, cabe registrar que, no que tange ao capital, o índice de capitalização continua sendo calculado com base na definição de capital regulamentar e de ativos ponderados pelo risco, sendo que o capital total permanece correspondente a, no mínimo, $8 \%$ (oito porcento) do APR e a proporção do capital de nível II permanece limitada ao montante do capital de nível I (BCBS, 2004b, p.22, § 40).

Sobre os níveis de capital, permanecem em vigor as definições de capital qualificado adotadas em Basiléia I, as quais referem-se aos recursos e instrumentos elegíveis para compor os três níveis de capital ${ }^{34}$.

Quanto à forma de cálculo do montante de capital a ser exigido para cobertura de cada um dos três tipos de riscos previstos, o documento base de Basiléia II trata extensamente do risco de crédito e, com menor detalhamento do risco operacional, remetendo à emenda de 1996 o tratamento do risco de mercado. $\mathrm{O}$ tratamento para tais riscos encontra-se descrito a seguir.

\subsubsection{Risco operacional}

"Risco operacional é definido como risco de perda resultante de pessoas, sistemas e processos internos inadequados ou deficientes, ou de eventos externos", o que inclui o risco legal, definido como sendo aquele "decorrente de exposições a multas, penalidades ou indenizações

\footnotetext{
${ }^{34}$ Exceto algumas modificações pontuais constantes em BCBS, 2004, § 37, 38, 39 e 43.
} 
em dinheiro resultantes de ações de supervisão, bem como de compensações a particulares" (BCBS, 2004b, p.163).

Os riscos operacionais podem ser tratados em Basiléia II por quatro métodos distintos, cuja sofisticação e sensibilidade ao risco são crescentes, guardando semelhanças conceituais com as abordagens para o risco de crédito, descritas mais adiante. No caso de risco operacional existem as seguintes opções de abordagens: do indicador básico, padronizada, padronizada alternativa e a abordagem de medições avançadas.

Pela abordagem de indicador básico o capital requerido para risco operacional é obtido multiplicando-se o resultado anual bruto do banco ${ }^{35}$ por um percentual alfa, estabelecido em $15 \%$.

$\mathrm{Na}$ abordagem padronizada, a base de cálculo continua sendo o resultado anual bruto da instituição financeira, enquanto que o cálculo do capital mínimo passa a ser realizado a partir de oito linhas de negócios pré-estabelecidas, com um multiplicador beta diferente para cada uma delas, conforme consta no Quadro 3.

Quadro 3 - Fatores para risco operacional

\begin{tabular}{|l|c|}
\hline Linhas de Negócios & Fatores beta \\
\hline Finanças corporativas & $18 \%$ \\
\hline Tesouraria & $18 \%$ \\
\hline Varejo & $12 \%$ \\
\hline Banco comercial & $15 \%$ \\
\hline Pagamentos e liquidações & $18 \%$ \\
\hline Serviços de agência & $15 \%$ \\
\hline Administração de ativos & $12 \%$ \\
\hline Corretagem de varejo & $12 \%$ \\
\hline
\end{tabular}

Fonte: BCBS, 2004b, p. 165, §654 e Anexo 8.

Cada fator beta serve como uma aproximação da relação entre a experiência de perda em risco operacional em uma determinada linha de negócios e o nível agregado do resultado bruto dessa linha de negócios.

\footnotetext{
${ }^{35}$ Média do resultado anual dos três últimos anos, eliminando-se eventuais resultados nulos ou negativos.
} 
Nessa abordagem, o capital requerido é a soma dos produtos desses percentuais beta pelos resultados apurados para cada uma dessas linhas de negócios.

$\mathrm{Na}$ abordagem padronizada alternativa, a única modificação refere-se às linhas de negócio de varejo e de banco comercial, onde o capital deixa de ser calculado a partir do resultado bruto e passa a ser apurado a partir de um percentual $(3,5 \%)$ do valor da carteira de empréstimos multiplicado pelo fator beta correspondente à linha de negócios.

As abordagens de medição avançada baseiam-se em modelos internos, sujeitos à aprovação prévia do órgão de supervisão. Tais modelos devem ser construídos a partir de bases de dados históricas de perdas coletadas pelas próprias instituições financeiras, as quais são segmentadas por linhas de negócios e por tipos de eventos de perda.

O Comitê da Basiléia padronizou sete grupos de possíveis eventos de perda a serem observados pelas instituições financeiras na coleta de dados, conforme detalhado no anexo 7 do documento "Convergência Internacional de Mensuração de Capital e Padrões de Capital”:

- fraudes internas;

- fraudes externas;

- práticas trabalhistas e segurança no trabalho;

- clientes, produtos e práticas comerciais; ${ }^{36}$

- danos aos ativos físicos;

- ruptura nos negócios e falhas em sistemas;

- administração de execução, entrega e processo. ${ }^{37}$

\subsubsection{Risco de mercado}

Para o tratamento do risco de mercado, continua em vigor o que veio a ser estabelecido na Emenda de 1996 para Risco de Mercado, mantendo-se a possibilidade de as instituições

\footnotetext{
${ }^{36}$ Perdas decorrentes de falha ou negligência no cumprimento de obrigações junto a clientes, ou decorrentes da natureza ou desenho de um produto.

${ }^{37}$ Perdas decorrentes de falhas transacionais ou decorrentes de relações com contrapartes comerciais.
} 
financeiras optarem por uma abordagem padronizada ou por uma abordagem mais sofisticada baseada nos modelos internos utilizados pelas próprias instituições para a administração desse risco.

$\mathrm{Na}$ abordagem padronizada, há a construção de um VaR - Value at Risk ${ }^{38}$ segundo um processo padronizado conforme diretrizes estabelecidas pelo órgão regulador. Esse VaR é calculado separadamente para as exposições a risco de taxas de juros, risco cambial, risco de ações e risco de commodities, desconsiderando eventuais correlações entre esses riscos.

No caso de risco de taxas de juros, as exposições são alocadas em faixas de vencimentos que variam do curto ao longo prazo e ponderadas em função de pesos pré-estabelecidos. Para risco cambial e risco de ações, o encargo de capital exigido é de $8 \%$ (oito porcento) da exposição líquida, enquanto que para o risco de commodities esse encargo é de $15 \%$ (quinze porcento) também da exposição líquida.

$\mathrm{Na}$ abordagem avançada, não há exigências quanto ao tipo de modelo que as instituições devem adotar, uma vez que a base dessa alternativa é a possibilidade de adoção dos próprios modelos utilizados internamente, desde que observadas determinadas exigências quantitativas e qualitativas em relação à gestão e mensuração de riscos.

Sobre as exigências qualitativas, destacam-se aspectos como a necessidade de que o controle de riscos seja independente das áreas de negócios e com reporte direto à alta administração, que os modelos utilizados para cálculo do capital sejam efetivamente utilizados no dia-a-dia da gestão de riscos, que esses modelos sejam internamente submetidos a processos de validação e, periodicamente, a testes de $\operatorname{estresse}^{39}$ e backtests $^{40}$ e, ainda, que haja documentação das políticas e procedimentos adotados.

\footnotetext{
${ }^{38} \mathrm{VaR}$ - Value at Risk (valor ou montante em risco) é normalmente definido na literatura como sendo o valor monetário da perda máxima esperada de uma carteira, sob condições normais de mercado, a um determinado nível de confiança e dentro de um horizonte de tempo.

${ }^{39}$ Testes de estresse são realizados mediante a simulação dos efeitos na carteira de cenários de perda extrema, como, por exemplo, a repetição das maiores perdas sofridas ou eventuais cenários de crises.

${ }^{40}$ Backtest consiste na comparação periódica da medida de risco com a perda efetivamente incorrida. No caso de risco de mercado, compara-se o VaR diário com a correspondente perda ou ganho no mesmo dia. Conforme o nível de confiança adotado no cálculo do $\mathrm{VaR}(99 \%$, por exemplo), espera-se que as perdas sejam inferiores ao VaR nesse mesmo percentual (99\% das vezes, no caso).
} 
Em relação às exigências quantitativas, destaque-se a necessidade do VaR ser calculado em bases diárias, com intervalo de confiança de 99\% monocaudal, utilizando-se um histórico de dados de pelo menos um ano. Além disso, existem também uma série de detalhamentos quantitativos em relação aos backtests e aos testes de estresse

Tanto em relação ao risco de mercado quanto em relação ao risco operacional, as observações acima constituem uma introdução dos tratamentos de Basiléia II para esses riscos, decorrência do foco deste trabalho em risco de crédito.

\subsubsection{Risco de crédito}

Para a mensuração do risco de crédito, Basiléia II apresenta três abordagens, também de crescente sofisticação e sensibilidade ao risco: uma primeira baseada em modelo padronizado e outras duas baseadas nos modelos que os bancos utilizam internamente, chamadas de abordagens IRB - Internal Ratings Based, sendo uma básica, denominada Foundation IRB e outra avançada, Advanced IRB.

\subsubsection{Abordagem padronizada}

A abordagem padronizada guarda semelhanças com Basiléia I, pois é baseada em categorias padronizadas de risco. São mais categorias, representando um conjunto mais amplo de ativos, cujos percentuais são padronizados também em função do risco apurado em cada crédito. $\mathrm{Na}$ apuração do risco de cada crédito, podem ser usadas avaliações realizadas externamente, como as realizadas por agências de classificação de $\operatorname{riscos}{ }^{41}$ previamente habilitadas junto ao órgão regulador.

As classes de risco padronizadas reconhecidas são as seguintes:

- Soberano: exposições a governos centrais e bancos centrais;

- PSE - Public Sector Entities: entidades não federais do setor público, como governos regionais e órgãos administrativos;

\footnotetext{
${ }^{41}$ Também referenciadas como agências de rating,
} 
- MDB - Multilateral Development Banks: bancos multilaterais de desenvolvimento, como BID e BIRD;

- Bancos: crédito interbancário;

- Corretoras e distribuidoras;

- Corporate: créditos a grandes empresas;

- Varejo: Crédito com características típicas de varejo, como diversificação, baixas exposições individuais e direcionado a pessoas físicas e jurídicas de pequeno porte;

- Hipotecas residenciais;

- Hipotecas comerciais;

- Vencidos: parte não coberta por garantia em créditos vencidos há mais de 90 (noventa) dias;

- Riscos elevados: créditos classificados abaixo de B-(soberanos), BB- (corporate);

- Outros ativos: não enquadrados nas categorias acima.

Com base nas categorias de ativos acima relacionadas e na classificação de risco atribuída, aplicam-se fatores de ponderação, que podem ser variáveis em função do risco ou não.

No caso de créditos soberanos, bancos, corporates, esses fatores são variáveis em função do risco individualmente atribuído a cada crédito. No caso de créditos de varejo e hipotecas, esses fatores de ponderação são fixos.

Quando se tratam de créditos vencidos, os fatores de ponderação variam 50 a $150 \%$ (cinquenta a cento e cinquenta porcento) do valor do crédito, de modo inversamente proporcional à cobertura de provisões.

O Quadro 4, a seguir, apresenta os fatores de ponderação das principais classes de ativos. 
Quadro 4 - Ponderação de risco das principais classes de ativos

\begin{tabular}{|c|c|c|c|c|c|c|}
\hline \multirow{2}{*}{$\begin{array}{c}\text { EXPOSIÇÃO DE } \\
\text { CRÉDITO }\end{array}$} & \multicolumn{6}{|c|}{ AVALIAÇÃO DE RISCO } \\
\hline & AАA/AA- & $\mathrm{A}+/ \mathrm{A}-$ & BBB $+/$ BBB- & $\mathbf{B B}+/ \mathbf{B}-$ & Abaixo B- & $\begin{array}{c}\text { Não } \\
\text { classificados }\end{array}$ \\
\hline Soberanos & $0 \%$ & $20 \%$ & $50 \%$ & $100 \%$ & $150 \%$ & $100 \%$ \\
\hline Bancos - opção 1 & $20 \%$ & $50 \%$ & $100 \%$ & $100 \%$ & $150 \%$ & $100 \%$ \\
\hline Bancos - opção $2^{42}$ & $20 \%$ & $50 \%$ & $50 \%$ & $100 \%$ & $150 \%$ & $50 \%$ \\
\hline Bancos - curto prazo & $20 \%$ & $20 \%$ & $20 \%$ & $50 \%$ & $150 \%$ & $20 \%$ \\
\hline Corporates & $20 \%$ & $50 \%$ & $100 \%$ & $100 \%$ & $150 \%$ & $100 \%$ \\
\hline Hipoteca residencial & \multirow{3}{*}{\multicolumn{5}{|c|}{ Não se aplica }} & $35 \%$ \\
\hline Hipoteca comercial & & & & & & $100 \%$ \\
\hline Varejo & & & & & & $75 \%$ \\
\hline
\end{tabular}

Fonte: BCBS (2004b, p.25, § 53 a 89) e BCB (2006, p.20)

Sua aplicação pode ser exemplificada da seguinte forma: um crédito detido por uma instituição financeira contra uma grande empresa classificada como risco AA será ponderado a $20 \%$ (vinte porcento) do seu valor para cômputo do APR. Assim, o capital alocado para a cobertura desse risco especificamente será o equivalente a 1,6\% do valor da exposição ( $8 \%$ do APR). O risco, quando válido para determinação do fator de ponderação, é apurado com base na classificação das agências de classificação de riscos.

Um aspecto que limita o alcance da abordagem padronizada é justamente essa característica de atrelamento dos fatores de ponderação à avaliação das agências de classificação de riscos. São poucos os países que têm mercados de classificação de risco desenvolvidos, com volume relevante de empresas e créditos devidamente analisados e classificados, a ponto de criar um vínculo efetivo entre o risco e o capital bancário, conforme tratado pelo BID ao discutir a implantação de Basiléia II na América Latina (2005, p.246).

Dentro desse contexto, também no Brasil não serão utilizadas as classificações de riscos divulgadas pelas agências de rating para fins de apuração dos requerimentos de capital, conforme o Comunicado do Banco Central de número 12.746, de 9 dezembro de 2004. Para a maioria das instituições será aplicada uma abordagem padronizada simplificada, que ainda assim constitui um aprimoramento da abordagem então vigente.

\footnotetext{
${ }^{42}$ Há duas possibilidades de tratamento para os créditos interbancários, cuja escolha fica a critério de cada órgão regulador nacional.
} 
Sobre a abordagem padronizada simplificada, cabe esclarecer que, segundo o próprio Comitê da Basiléia, "Esse método não deve ser considerado como um outro método para determinar o capital regulamentar. Em vez disso, ele coleta em um único lugar as opções mais simples para calcular os ativos de risco ponderado" (BCBS, 2004b, p.249, anexo 9)

A abordagem padronizada inclui outros elementos, além dos fatores de ponderação de capital, dentre os quais os principais são fatores de conversão de itens fora de balanço e a possibilidade de aceitação de técnicas de mitigação de risco.

\subsection{Fatores de conversão para itens extrapatrimoniais}

No caso de itens que não se encontram registrados nas contas patrimoniais, como avais, fianças, compromissos ${ }^{43}$, mas que representam exposições potenciais de crédito, tais itens são convertidos em elementos do APR mediante a aplicação de fatores de conversão de crédito (CCF - Credit Conversion Factor) sobre os seus valores de exposição.

Os CCFs são pré-estabelecidos pelo Comitê e encontram-se sintetizados abaixo, no Quadro 5:

\section{Quadro 5 - Fatores de conversão de crédito}

\begin{tabular}{|c|l|}
\hline CCF & \multicolumn{1}{|c|}{ Descrição } \\
\hline $0 \%$ & $\begin{array}{l}\text { Compromissos canceláveis sem aviso prévio ao tomador ou em decorrência de deterioração no risco } \\
\text { (limites pré-aprovados) }\end{array}$ \\
\hline $20 \%$ & $\begin{array}{l}\text { Compromissos com prazo de até um ano e cartas de crédito comerciais autoliquidáveis de curto prazo } \\
\text { (limites de cheque especial ou similares) }\end{array}$ \\
\hline $50 \%$ & $\begin{array}{l}\text { Compromissos com prazo superior a um ano (fiança bancária a instituição financeira, cessão de crédito } \\
\text { com coobrigação, cartas de crédito de importação confirmadas) }\end{array}$ \\
\hline $100 \%$ & $\begin{array}{l}\text { Outros compromissos (fianças bancárias a não financeiras, cartas de crédito de importação, } \\
\text { empréstimos de TVMs ou entrega de títulos em garantia) }\end{array}$ \\
\hline
\end{tabular}

Fonte: BCBS (2004b, p.32, §82 a 89) e BCB (2006, p.19)

\footnotetext{
${ }^{43}$ Limites de crédito e créditos pré-aprovados.
} 


\subsection{Mitigação de risco de crédito - CRM}

A mitigação de risco de crédito (CRM - Credit Risk Mitigation) refere-se à possibilidade de uso de técnicas de redução ou transferência do risco de crédito para fins de atenuação das exigências de capital.

Alguns pré-requisitos são necessários para que esses mitigadores possam ser reconhecidos, principalmente em relação ao que o Comitê denomina como "certeza legal" sobre os mesmos (BCBS, 2004b, p.38, § 117):

- que todos os contratos estejam devidamente documentados;

- que todas as partes envolvidas estejam devidamente vinculadas nesses contratos;

- que esses contratos sejam legalmente executáveis nas jurisdições competentes; e

- que os bancos conduzam revisão legal suficiente para assegurar as condições acima continuamente.

Além desses requisitos de natureza legal, tampouco deve haver correlação positiva entre o risco de crédito do tomador dos recursos e o valor da garantia.

São duas as possibilidades de uso de CRM, uma alternativa simples e uma alternativa abrangente. Na alternativa simples, utilizada somente na abordagem padronizada, o Comitê estabeleceu que o mitigador deve estar vinculado no mínimo pelo mesmo prazo da exposição e ainda que esse mitigador seja avaliado a preços de mercado a cada seis meses. O Comitê também define três classes de mitigadores aceitáveis para fins de CRM: garantias financeiras, compensação de recursos e avais, fianças e derivativos de crédito.

Se cumpridos esses requisitos, a parte do crédito que estiver coberta pela garantia pode ser ponderada pelo fator de risco do garantidor, sujeito a um piso de $20 \%$ na maioria das situações.

$\mathrm{Na}$ alternativa abrangente, utilizada tanto na abordagem padronizada quanto na abordagem Foundation IRB, permite-se a compensação efetiva da garantia com a exposição, mas são feitos ajustes para determinar o valor a ser compensado. Esse valor é calculado a partir de taxas de descontos relacionadas tanto ao valor da exposição quanto às flutuações no preço de 
mercado das garantias, sendo que tais taxas de desconto podem ser arbitradas pela supervisão ou calculadas pelos próprios bancos. ${ }^{44}$

No caso da abordagem Advanced IRB, os efeitos dos mitigadores de risco de crédito estão considerados nos componentes que tratam da exposição e da perda, conforme discutido a seguir.

\subsubsection{Abordagens baseadas em modelos internos - IRB}

No caso das abordagens baseadas em modelos internos, Foundation IRB e Advanced IRB, as duas opções dependem de autorização previa da supervisão bancária para seu uso e baseiamse em fórmulas de cálculo estabelecidas pelo Comitê.

Essas fórmulas têm como dados de entrada a probabilidade de inadimplência do crédito (PD probability of default), o valor da estimado da exposição no momento do inadimplemento (EAD - exposure at default), a perda estimada dado o inadimplemento (LGD - loss given default) e o prazo ( $M$ - maturity) e apresentam como resultado a exigência de capital para risco de crédito com nível de confiança de 99,9\% (noventa e nove porcento e nove décimos).

$\mathrm{Na}$ abordagem básica os bancos calculam apenas a PD, enquanto a LGD, a EAD e M são arbitrados pelo órgão regulador. Na abordagem avançada, o banco deve calcular todos os parâmetros de entrada. Tanto em uma abordagem quanto em outra os dados de entrada devem ser coletados e/ou estimados pelos próprios bancos para cada crédito ou carteira e são usados como parâmetros para equações pré-determinadas normativamente cujo resultado é o encargo de capital exigido da instituição financeira para o risco de crédito.

No entanto, para que as instituições possam utilizar essas abordagens, todo o processo de mensuração e gestão do risco de crédito deve ser avaliado e aprovado previamente pela supervisão bancária. Para aceitação pela supervisão dos sistemas de mensuração de risco das instituições, tais modelos devem cumprir uma série de requisitos (BCBS, 2004, p.99 a 124, § 389 a 505), sintetizados a seguir.

\footnotetext{
${ }^{44}$ Tanto a alternativa simples quanto a alternativa abrangente apresentam um nível de detalhamento que excede o escopo desta pesquisa. Podem ser vistas em detalhe em BCBS, 2004b, p. 37, § 109 a 210.
} 
Primeiramente, o sistema de classificação ${ }^{45}$ deve observar alguns requisitos quanto ao seu desenho. No caso das carteiras de crédito corporate, soberano e bancos, devem ser observadas duas dimensões em separado: o risco associado ao cliente tomador do crédito e o risco associado às características de suas operações. Implicitamente, na primeira dimensão avaliase a PD e na segunda a LGD, mediante o potencial montante a ser recuperado se o tomador inadimplir. No caso das carteiras de varejo, as duas dimensões devem ser tratadas de modo simultâneo, avaliando-se as exposições por grupos homogêneos. As descrições dessas faixas de risco devem ser detalhadas para assegurar consistência interna e verificabilidade por terceiros.

Quanto à estrutura, o sistema deve apresentar uma diferenciação adequada e desconcentrada de risco, contando, no caso das carteiras corporate e similares com pelo menos oito faixas de risco, uma delas destinadas aos inadimplentes. No caso do varejo, a separação em grupos homogêneos deve assegurar que haja um número suficiente de elementos em cada um desses grupos para que as perdas esperadas tenham significado estatístico.

Na modelagem estatística, com base em dados de natureza quantitativa e qualitativa, cabe aos bancos demonstrar a eficiência preditiva dos seus modelos, bem como validá-los, além de documentá-los detalhadamente, inclusive quanto ao funcionamento e operação do sistema.

Todas as operações devem ser avaliadas, seja por sistemas de classificação de rating seja por agrupamento em grupos homogêneos, sendo validadas observando princípios de segregação de funções, ou seja, por partes não interessadas e também pela auditoria interna. As avaliações de risco também devem ser atualizadas periodicamente, no caso dos ratings, pelo menos anualmente.

Os sistemas de classificação utilizados para fins de alocação de capital devem realmente ser utilizados pelo banco nas suas atividades normais, isto é, para conceder, precificar e gerenciar risco de crédito. Essa questão é fundamental pois faz parte da própria base conceitual de Basiléia II, de aproximar o capital regulatório do capital econômico calculado pelos próprios bancos.

\footnotetext{
${ }^{45}$ A expressão "sistema de classificação" abrange "todos os métodos, processos, controles e coleta de dados e sistemas de TI que dão suporte à avaliação do risco de crédito, à atribuição de classificações de risco internas e a quantificação de estimativas de perdas e inadimplemento.” (BCBS, 2004, p.99, §394)
} 
O processo de validação constitui responsabilidade primária das instituições financeiras, que têm o dever de validar a precisão e consistência dos sistemas de classificação de riscos. No entanto, para autorizar seu uso, o órgão supervisor necessita rever os processos de validação internos, podendo inclusive implementar métodos adicionais de validação se necessário.

Essa revisão pelo órgão supervisor tende a verificar alguns aspectos, como por exemplo, a análise do poder discriminatório dos modelos adotados e sua respectiva calibragem.

No primeiro caso, busca-se verificar se os modelos separam efetivamente os bons dos maus clientes, isto é, os que irão pagar seus débitos daqueles que virão a inadimplir. Quanto maior o poder de discriminação, menor a proporção dos dois tipos comuns de erros: admitir em carteira maus clientes ou deixar de operar com bons clientes. No que trata da calibragem, o objetivo é verificar se a inadimplência prevista aproxima-se das observadas, o que pode ser feito mediante a comparação desses dois resultados.

Adicionalmente pode ser utilizada uma referência externa para auxiliar o processo de validação, comparando as estimativas da instituição financeira para determinados clientes com as de seus pares no mercado ou mesmo de agências de ratings para os mesmos clientes.

Tais comparações trazem um elemento empírico e concreto a esse processo de validação, trazendo suporte de natureza mais concreta e de compreensão mais imediata a eventuais argumentos da supervisão quando de uma eventual invalidação de um sistema de classificação.

Com base nesses aspectos abordados, é possível sintetizar as abordagens IRB do seguinte modo: que os elementos fundamentais para o cálculo do capital exigido são medidos e estimados pelos próprios bancos, através de processos complexos e com diversas características de subjetividade decorrentes dos próprios critérios de avaliação de risco de crédito, cabendo à supervisão bancária aceitar ou rejeitar esses processos previamente à sua entrada em prática. Esse destaque torna-se mais relevante quando se compara e discute a 
relação da supervisão bancária brasileira ${ }^{46}$ com os bancos supervisionados a partir da edição da Resolução CMN 2.682/99

\subsection{Pilar 2 - Revisão pela supervisão}

\subsubsection{Objetivos do Pilar 2 e os quatro princípios}

O Pilar 2 visa assegurar que os bancos mantenham um nível de capitalização adequado aos riscos dos seus negócios e também incentivar as instituições financeiras a aperfeiçoar suas técnicas de gerenciamento de riscos. O papel reservado à supervisão é o da revisão e avaliação crítica da eficácia dos bancos na mensuração das suas necessidades de capital, intervindo se necessário, tanto por medidas que impliquem a redução dos riscos quanto pela restauração do nível de capital.

Segundo o Comitê da Basiléia, existem algumas questões cujo tratamento deve se dar no âmbito desse pilar, notadamente riscos não tratados no Pilar 1, como o risco de concentração e os riscos de estratégia e reputação, bem como eventuais efeitos do ciclo de negócios. Também devem ser objeto de atenção no Pilar 2 a avaliação do cumprimento dos critérios de qualificação e dos padrões mínimos para adoção das abordagens IRB para risco de crédito e da abordagem avançada para risco operacional.

O Pilar 2 ampara-se em quatro princípios-chave:

- que exista uma avaliação da própria instituição financeira sobre a adequação do seu nível de capital em relação ao seu perfil de risco e uma estratégia para manutenção dos níveis de capital;

- que esse processo seja revisado pela supervisão, que deve revisar e julgar (se necessário intervir) as avaliações e estratégias de adequação interna de capital dos bancos, bem como sua habilidade em monitorar e assegurar a manutenção da capitalização necessária;

- que os bancos operem com capital acima do mínimo regulamentar e que os supervisores tenham a habilidade de obrigar as instituições nesse sentido; e

\footnotetext{
${ }^{46}$ No que se refere ao risco de crédito.
} 
- que a supervisão intervenha antecipadamente para evitar que os bancos caiam abaixo do mínimo ou que possa requerer rápida ação corretiva caso o capital não seja mantido ou restabelecido.

\subsubsection{Princípios 1 e 2: auto-avaliação e revisão pela supervisão}

Em relação ao primeiro princípio é importante distinguir entre a existência de modelos quantitativos de mensuração de risco e o processo de auto-avaliação pela instituição, onde os modelos são uma parte, mas não representam o conjunto desse processo. Também é importante destacar que o Pilar 2, que trata do processo de revisão pela supervisão, inicia-se por iniciativa e responsabilidade da própria instituição financeira, uma vez que essa primeira revisão é um processo de natureza interna aos bancos, que envolve a alta administração e inclui a avaliação abrangente do capital e dos riscos e a revisão dos mecanismos de monitoramento e reporte e dos controles internos.

Quanto à revisão pela supervisão, o segundo princípio, implica uma ação periódica da supervisão, mediante fiscalizações diretas e indiretas e discussões com a direção da instituição financeira, avaliando a adequação dos seguintes aspectos:

- avaliação de riscos;

- adequação de capital;

- ambiente de controle;

- cumprimento dos padrões mínimos, no caso de utilização de técnicas de CRM ou abordagens baseadas em modelos internos.

Segundo o Comitê da Basiléia, a manutenção dos níveis de capital acima do mínimo regulamentar, objeto do terceiro princípio, é uma atitude esperada por parte dos bancos, dado que as flutuações normais nos negócios podem causar oscilações no índice de capitalização, podendo a obtenção de capital adicional vir a ser custosa ou inviável a depender das condições de mercado. Também os critérios dos avaliadores externos (agências de rating, investidores) tendem a considerar os índices de capitalização na tomada de decisões. 
Podem também existir riscos específicos para bancos individuais, ou característicos de um segmento específico, que não foram considerados no Pilar 1. Tais riscos devem ser avaliados e podem ensejar uma exigência de um nível adicional na proporção de capital, acima dos $8 \%$ (oito porcento) para um banco ou segmento específicos.

\subsubsection{Princípios 3 e 4: enforcement do supervisor}

De todos os pontos levantados, o mais relevante em relação ao terceiro princípio é o fato de que a queda abaixo do nível mínimo de capital deve colocar os bancos como infratores de leis e regulamentos aplicáveis ao setor, tornando-se passíveis de ação corretiva imediata por parte dos supervisores.

Tem-se aí de uma questão fundamental em supervisão e essencial para o funcionamento adequado de Basiléia II: o enforcement, o poder de obrigar de fato os bancos a cumprirem as normas, questão abordada também no quarto princípio, que elenca algumas medidas passíveis de adoção pelos supervisores, como a intensificação da fiscalização da instituição financeira problemática, a restrição ao pagamento de dividendos e outras retiradas, a exigência de um plano de capitalização e, ainda, o levantamento adicional de recursos de imediato. Segundo o Comitê, os supervisores devem ter poder discricionário para utilizar as ferramentas mais adequadas a cada situação.

O que vale destacar nessa questão é que sem um poder discricionário efetivo do órgão regulador, não há a implementação adequada de Basiléia II. No caso de se mostrarem inadequados os requisitos de capital medidos pelos próprios bancos no Pilar 1, o que assegura a autocorreção do sistema é justamente a discricionariedade existente no Pilar 2.

Uma questão decorrente refere-se aos limites desse poder discricionário do regulador e como a aplicação desse poder é afetada por conta do ambiente legal de cada país, quando se tratam de sistemas baseados em usos e costumes, o direito consuetudinário de tradição anglo-saxã, ou nos casos baseados em códigos, o direito de tradição romano-germânica. Ou ainda, sobre como seriam recebidas pelo poder judiciário medidas adotadas com base em normas de caráter mais aberto, a exemplo de como seriam os processos que eventualmente levariam à 
invalidação dos modelos de uma instituição financeira, à requisição de capital adicional e, no caso extremo, à liquidação de uma instituição.

A esse respeito Gorga e Stajn (2005, p.139) apontam justamente que a diferença entre os sistemas legais "[...] é uma das dificuldades para quem pretende transpor ou aplicar normas ou práticas de um para outro ordenamento nacional." e destacam também que "[...] é perceptível a influência de modelos negociais desenhados em países de direito consuetudinário que ganham espaço naqueles de direito codificado", o que constitui precisamente o caso de Basiléia II.

Este trabalho não pretende responder a essa questão, apenas realçar que essas são dificuldades que podem se tornar relevantes no momento em que os demais mecanismos falham e ocorre a quebra de uma instituição financeira. Nessa situação, tem-se que as decisões e ações do supervisor, tomadas dentro de um parâmetro normativo que guarda similaridade com a tradição consuetudinária, serão avaliadas por um poder judiciário que julga com base na tradição codificada.

Assim, “[...] os desafios para os reformadores em mercados emergentes incluem não somente o problema técnico de como desenhar um sistema regulatório eficaz, mas o problema mais difícil de como criar as circunstâncias políticas que fazem tal sistema ter credibilidade" ${ }^{47}$ (CALOMIRIS; POWELL, 2000, p.42), credibilidade essa que depende, fundamentalmente, do enforcement dos reguladores.

\subsection{Pilar 3 - Disciplina de mercado}

O Pilar 3 tem o papel de dar maior transparência aos agentes do mercado acerca dos riscos incorridos pelos bancos, sobre os níveis desses riscos e seu gerenciamento por parte das instituições financeiras (BCBS, 2004b, p.2004, §808). Segundo o próprio Comitê, constitui um meio adicional para reforçar a segurança e a solidez dos sistemas financeiros, ao

\footnotetext{
47 "[...] the challenges for reformers in emerging market countries include not only the technical problem of how to design an effective regulatory system, but the more difficult problem of how to create the political conditions that make such a system credible".
} 
complementar os Pilares 1 e 2 mediante a obrigatoriedade de divulgação periódica de um conjunto determinado de informações.

Sua base conceitual sustenta-se na idéia de que, se for possível disseminar de maneira eficiente informações suficientes, tempestivas e confiáveis sobre os riscos e níveis de capital mantidos pelos bancos, os agentes econômicos teriam elementos para decidir quais bancos punir e quais bancos recompensar, de modo que a auto-regulação pelo próprio mercado seria suficiente para levar à estabilidade financeira, uma vez que os próprios bancos se autoajustariam ao se perceberem sendo punidos pelo mercado, conforme Calomiris e Powell (2000, p.42):

\begin{abstract}
"Os mercados, tanto quanto os reguladores, punem ou recompensam os bancos dependendo do risco percebido de falência, e as percepções de risco do mercado (como indicado nas taxas de captação de depósitos e nos fluxos dessas captações) são correlacionadas tanto com as medidas de risco dos ativos quanto com a probabilidade futura de falência do banco. A disciplina de mercado incentiva rápidos ajustes por bancos aos choques que elevam seu risco de falência, por meio de medidas para a redução do próprio risco" 48
\end{abstract}

Alguns autores sustentam que o Pilar 3, mais do que os Pilares 1 e 2, deveria estar no topo das prioridades do Comitê da Basiléia e dos órgãos reguladores. Segundo Rochet (2004, p.14):

\begin{abstract}
“[...] nós sustentamos que [...] os escassos recursos supervisórios devem ser usados, de acordo com as prioridades, para controlar o comportamento dos bancos em dificuldades, mais do que para executar um regulamento extremamente complexo que será contornado finalmente, em alguma maneira ou em outra, pelos maiores ou mais sofisticados bancos. [...] A disciplina do mercado pode fornecer uma ferramenta muito útil para definir práticas harmônicas e sem impedimentos para autoridades de supervisão bancária através do mundo, em uma tentativa de eliminar eventuais pressões políticas e falhas regulatórias. Esta deveria ser a prioridade superior do comitê de Basiléia".
\end{abstract}

A implementação do Pilar 3 ocorre por meio da exigência de divulgação de um conjunto mínimo de informações de natureza quantitativa e qualitativa, sendo que quanto mais avançada a abordagem de mensuração de riscos, maior o conjunto de informações a serem

\footnotetext{
48“"Markets, as well as regulators, punish or reward banks depending on the perceived risk of bank failure, and market perceptions of risk (as indicated in deposit interest rates and deposit flows) are correlated both with ex ante measures of fundamental asset risk and with ex post incidence of bank failure. Market discipline encourages rapid, risk-reducing adjustments by banks to shocks that raise their risk of failure".

49 "[...] we argue that banking authorities should instead keep arm's-length relationships with bankers and that scarce supervisory resources should be used, according to priority, to control the behavior of banks in distress, rather than to implement an extremely complex regulation that will ultimately be bypassed in some way or another by the largest or most sophisticated banks.[...]Market discipline can provide a very useful tool for defining a harmonized and clear mandate for banking authorities across the world, in an attempt to eliminate political pressure and regulatory forbearance. This should be the top priority of the Basel Committee."
} 
disponibilizados sobre a estrutura do capital, a adequação do capital e sobre os riscos incorridos.

No caso de risco de crédito, exige-se de todos os bancos a divulgação de ${ }^{50}$ :

- Objetivos e políticas da gestão de risco de crédito, o que inclui estratégias, estrutura organizacional, escopo e natureza dos sistemas de mensuração de risco, políticas de mitigação de risco;

- Definições de inadimplência e de deterioração de risco;

- Descrição dos métodos para provisionamento;

- Total das exposições e seus respectivos tipos, subdivididas por distribuição geográfica, setorial, por vencimento;

- Valor dos empréstimos deteriorados.

Para as abordagens baseadas em modelos internos de mensuração de risco de crédito, acrescente-se aos itens acima a divulgação de itens como $^{51}$ :

- Aceitação da autoridade de supervisão quanto ao uso do método IRB;

- Explicação da estrutura dos sistemas de classificação, dos mecanismos para mitigação de risco e dos mecanismos de controle interno;

- Descrição do processo de classificação, separadamente para as principais carteiras definidas segundo a regulamentação, incluindo os tipos de exposição e as definições e métodos para estimar PD, EAD e LGD;

- Apresentação, para cada carteira, do total de exposições em aberto, estratificada por níveis de PD ou, no caso de varejo, por níveis de perdas esperadas;

- Perdas reais no período anterior e comparação com o período anterior e com a experiência histórica.

No caso de uso de instrumentos de mitigação de risco de crédito, exige-se a divulgação de, entre outros, elementos como as políticas e processos para avaliação e gerenciamento de garantias, a descrição dos principais tipos de garantias, avalistas e contrapartes em derivativos

\footnotetext{
${ }^{50}$ Principais elementos de divulgação. Para detalhamento, ver BCBS, 2004b, p.211 a 215.

${ }^{51}$ Principais elementos de divulgação. Para detalhamento, ver BCBS, 2004b, p.211 a 215.
} 
de crédito, informações sobre eventuais concentrações de risco dentro da mitigação feita e, ainda, o detalhamento quantitativo por tipo de mitigação.

Os itens acima trazem os principais tipos de informação exigidos para risco de crédito. Em cada um dos itens apontados há detalhamentos ou subdivisões que devem ser apresentados pelas instituições financeiras para que os requisitos de divulgação do Pilar 3 sejam considerados cumpridos. Dessa forma, tende a aumentar de modo significativo o volume de informações à disposição dos analistas e investidores, possibilitando testar se a redução nas assimetrias de informação comprova pontos de vista como o de Rochet e outros autores.

\subsection{Comentários sobre Basiléia II}

Basiléia II tem um viés baseado em princípios de auto-regulação, em que se tem uma delegação cada vez maior aos próprios agentes do mercado a definição das regras de participação nesses mercados. (LIMA, 2005; CARVALHO, 2005).

Tal caráter pode ser percebido nas abordagens baseadas em modelos internos do Pilar 1 e na fundamentação conceitual do Pilar 3, mas aparece também no próprio Pilar 2, que, ao tratar da ação da revisão pela supervisão, estabelece como primeira etapa a auto-revisão de procedimentos pelo regulado.

Esse caráter cada vez mais nítido de auto-regulação pelo próprio mercado pode ser caracterizado, em linhas gerais, como a "tendência de devolução da responsabilidade pelos riscos assumidos aos próprios bancos”, ao estender a possibilidade de o próprio banco definir e mensurar os riscos a que está sujeito (CARVALHO, 2005, p.139). São essas características de Basiléia II que levam a alguns aspectos que demandam análise adicional.

Basiléia II foi desenvolvido para os países membros do G-10, conforme consta em sua própria introdução (BCBS, 2004b, p.11), portanto, primordialmente para economias desenvolvidas, ainda que tenham sido feitas diversas rodadas de consultas a diversos países em sua fase de elaboração. 
Do mesmo modo que ocorreu com Basiléia I, espera-se que Basiléia II também venha a ser adotado num grupo maior de países que apenas os membros do Comitê da Basiléia. Tal afirmação é suportada pelo próprio Comitê, no texto introdutório de Basiléia II, ao informar que aquele documento está "sendo enviado para as autoridades de supervisão de todo o mundo com a intenção de encorajá-las a considerar a sua adoção", ainda que no momento em que julgarem mais conveniente.

Pelo fato de Basiléia II ter sido criado em função das economias desenvolvidas, decorre uma série de questões que merecem aprofundamento e discussão tendo em conta as características diferenciadas dos chamados países emergentes (BID, 2005):

- a baixa penetração das agências de classificação de risco (agências de rating) nos países emergentes, base das abordagens mais simples, que seriam adequadas para os bancos menos complexos desses países;

- as possibilidades de uso de centrais de risco de crédito (bancos de dados privados ou públicos) na criação de alternativas simplificadas aos modelos internos, para uso em países emergentes, bem como suporte à validação de modelos internos (POWELL,2004; TRUCHARTE, 2004);

- as dificuldades na definição e implementação do processo de aprovação dos modelos internos pelos órgãos de supervisão;

- as questões institucionais, notadamente o enforcement de direito e de fato dos órgãos reguladores, aspecto fundamental para adotar medidas punitivas/restritivas frente a um sistema baseado na auto-regulação.

Esses aspectos merecem análise com base na experiência propiciada pela aplicação da norma brasileira para risco de crédito, a Resolução CMN 2.682/99. Trata-se de um normativo que apresenta características de auto-regulação na definição das provisões contábeis, calculadas a partir de métodos internos de classificação de risco. Sua análise contribui para a elucidação de questões como a validação de modelos internos, seu uso para apuração do capital regulatório, bem como dos limites e dificuldades que a tradição legal brasileira, de direito codificado, impõe a mecanismos auto-regulatórios. 
Por conta desses aspectos, torna-se relevante analisar de maneira minuciosa a Resolução CMN 2.682/99 e sua aplicação no país, como meio de suporte à compreensão dos desafios relativos à implementação de Basiléia II no Brasil.

\subsection{Implementação de Basiléia II no Brasil}

\subsubsection{Cronograma de implantação}

O Comunicado 12.746, de 09 de dezembro de 2004, emitido pelo Banco Central do Brasil, foi o instrumento que publicou as principais diretrizes e o cronograma para adoção de Basiléia II no país. O cronograma original foi posteriormente alterado pelo Comunicado 16.137, de 27 de setembro de 2007, resumido de modo comparado a seguir:

- etapas cumpridas em agosto e setembro de $2007^{52}$ :

- revisão dos requerimentos de capital para risco de crédito na abordagem simplificada (previsão original: final de 2005);

- introdução de parcelas de requerimento de capital para risco de mercado ainda não contempladas pela regulamentação (previsão original: final de 2005);

- até final de 2007:

- estabelecimento da parcela de requerimento de capital para risco operacional nas abordagens básica ou padronizada alternativa (previsão original: final de 2007);

- até final de 2008:

- estabelecimento dos critérios de elegibilidade para adoção de modelos internos para risco de mercado (previsão original: final de 2007);

- divulgação do processo de solicitação de autorização para uso de modelos internos para risco de mercado (sem previsão original);

- implementação de estrutura para gerenciamento de risco de crédito e divulgação dos pontos-chave necessários para formatação da base de dados para modelos internos de risco de crédito (sem previsão original);

\footnotetext{
${ }^{52}$ Item não constante do novo cronograma, anotado apenas para fins de comparação com o cronograma original.
} 
- até final de 2009:

- início do processo de autorização para uso de modelos internos de risco de mercado (previsão original: 2008 e 2009);

- estabelecimento dos critérios de elegibilidade para adoção de modelos internos para risco de crédito (previsão original: final de 2007);

- divulgação do processo de solicitação de autorização para uso de modelos internos para risco de crédito (sem previsão original);

- divulgação dos pontos-chave para uso de modelos de risco operacional (sem previsão original);

- até final de 2010:

- início do processo de autorização para uso de modelos internos de risco de crédito - abordagem básica (previsão original: 2008 e 2009);

- até final de 2011:

- início do processo de autorização para uso de modelos internos de risco de crédito - abordagem avançada (previsão original: 2009 e 2010);

- estabelecimento dos critérios de exigibilidade para adoção de modelos internos para risco operacional (previsão original: 2008 e 2009);

- divulgação do processo de solicitação de autorização para uso de modelos internos para risco operacional (sem previsão original);

- até final de 2012:

- início do processo de autorização para uso de modelos internos de risco operacional (previsão original: 2010 e 2011).

\subsubsection{Primeiras alterações normativas: EPR e cálculo do PRE}

No que se refere às exigências de capital mínimo, o Conselho Monetário Nacional, mediante a edição da Resolução 3.490, de 29 de agosto de 2007, estabeleceu que o montante de capital regulamentar a ser mantido pelas instituições passou a ser dado pelo PRE - Patrimônio de Referência Exigido.

O PRE consiste na soma de seis parcelas, cada qual relativa a um tipo de risco, conforme a fórmula a seguir: 
$P R E=P_{E P R}+P_{C A M}+P_{J U R}+P_{C O M}+P_{A C S}+P_{O P R}$, em que:

- $P E P R=$ parcela referente às exposições ponderadas pelo fator de ponderação de risco a elas atribuído;

- $P_{C A M}=$ parcela referente ao risco das exposições em ouro, em moeda estrangeira $\mathrm{e}$ em operações sujeitas à variação cambial;

- $P J U R=$ parcela referente ao risco das operações sujeitas à variação de taxas de juros;

- $P_{C O M}=$ parcela referente ao risco das operações sujeitas à variação do preço de mercadorias (commodities);

- $\quad P_{A C S}=$ parcela referente ao risco das operações sujeitas à variação do preço de ações;

- $P O P R=$ parcela referente ao risco operacional.

Sobre os requisitos de capital para risco de crédito, em 12 de setembro de 2007, a direção do BACEN aprovou nove circulares, cuja vigência se dará a partir de $1^{\circ}$ de julho de $2008,^{53}$ que detalham os critérios e fórmulas para o cálculo dos requerimentos de capital relativos ao EPR - Exposição Ponderada pelo Risco ${ }^{54}$ - e aos fatores de risco de mercado, que incluem ações, commodities, taxa de juros, câmbio e cupons de juros e moedas estrangeiras.

O EPR, objeto da Circular 3.360/07, apresenta novos fatores de ponderação de risco de crédito dos ativos em moldes similares à abordagem padronizada simplificada de Basiléia II, sendo mantida a exigência de capital de $11 \%$ (onze porcento), dada por um fator denominado F - Fator de Exigência de Capital, de 0,11 a ser aplicado sobre o EPR. ${ }^{55}$

Conforme a Nota à Imprensa divulgada pelo BACEN em 14 de setembro de 2007:

"Seguindo as recomendações de Basiléia II, as contrapartes são identificadas por faixas de ponderação de risco, a exemplo da metodologia já em vigor no Brasil desde 1994. São sete faixas de ponderação de risco, que correspondem ao respectivo FPR: 0\%, 20\%, 35\%, 50\%, 75\%, 100\% e $300 \%$. Essas ponderações são aplicadas às exposições de uma instituição (operações ativas e demais operações que possam implicar algum risco de crédito, a exemplo de compromissos e

\footnotetext{
${ }^{53}$ Aapuração da exposição cambial tem vigência imediata.

${ }^{54}$ Substitui o APR.

${ }^{55}$ Para cooperativas de crédito a exigência de capital varia entre 13 (treze) e 17\% (dezessete porcento), enquanto para as agências de fomento a exigência foi reduzida de 30 (trinta) para $11 \%$ (onze porcento).
} 
garantias), segundo as características de cada operação. O somatório das exposições ponderadas pelo respectivo FPR constitui a Exposição Ponderada pelo Risco (EPR), ao qual é aplicado o fator F de requerimento de capital."

A referida Nota à Imprensa destaca ainda as principais alterações nos Fatores de Ponderação de Risco - FPR:

- Criação de Fator de Conversão de Crédito - FCC, a ser aplicado sobre os compromissos de crédito não canceláveis unilateral e incondicionalmente pela instituição, que será de $20 \%$ para aqueles compromissos com prazo inferior a 1 ano e de $50 \%$ para os compromissos que tenham prazo superior a 1 ano;

- FPR de 0\% para as exposições às entidades do Grupo Banco Mundial e uma série de organismos internacionais e entidades multilaterais de desenvolvimento;

- FPR de $20 \%$ para operações com vencimento em até três meses, em moeda nacional, realizadas entre instituições financeiras;

- Novo FPR de 35\% a ser aplicado ao financiamento de imóveis residenciais garantidos por hipoteca ou alienação fiduciária cujos valores contratados não superem $50 \%$ do valor da garantia, na data da concessão do crédito, bem como aos Certificados de Recebíveis Imobiliários - CRI com lastro nessas operações; ${ }^{56}$

- FPR de 50\% para as operações de financiamentos habitacionais garantidos por hipoteca ou alienação fiduciária cujos valores contratados estejam situados entre $50 \%$ e $80 \%$ do valor da garantia, na data da concessão do crédito, bem como aos Certificados de Recebíveis Imobiliários - CRI com lastro nessas operações; ${ }^{57}$

- Novo FPR de 75\% para os créditos classificados como de varejo, dado que tais carteiras têm menor risco em função de sua maior diversificação, pois englobam operações de pequeno valor e contrapartes de pequeno porte; ${ }^{58}$

\footnotetext{
${ }^{56} \mathrm{O}$ mesmo fator deve ser aplicado também a financiamentos garantidos por hipoteca de imóvel residencial, desde que os valores contratados não superem $50 \%$ do valor de avaliação da garantia, na data da concessão do crédito.

57 Também para financiamentos garantidos por hipoteca de imóvel residencial nos casos de valores contratados situados entre $50 \%$ e $80 \%$ do valor de avaliação da garantia, na data da concessão do crédito. O fator de $50 \%$ também vale para os financiamentos para construção de imóveis, garantidos por alienação fiduciária ou hipoteca, desde que adotado o patrimônio de afetação e os CRI com lastro nas operações de crédito imobiliário elegíveis a tal FPR. Aplica-se esse FPR também a operações de crédito com câmara ou prestador de serviços de compensação e de liquidação sistemicamente importante.

${ }^{58}$ Para serem enquadradas na categoria de varejo, as operações devem atender a todos os seguintes requisitos: a) contraparte pessoa física ou jurídica de pequeno porte (receita bruta inferior a R \$2,4 milhões anuais); b) valor das operações com uma mesma contraparte inferior a $\mathrm{R} \$ 400$ mil; c) valor das operações com uma mesma contraparte inferior a $0,2 \%$ do total da carteira de varejo; d) instrumento financeiro típico de varejo;
} 
- Alteração da ponderação de risco para aplicações em cotas de fundos de investimento, inclusive cotas de Fundo de Investimento em Direitos Creditórios - FIDC, que passam a receber o FPR de $100 \% ;{ }^{59}$

- Redução do FPR para a parte do crédito protegida quando da existência de mitigadores de risco de crédito, segundo a natureza do mitigador. ${ }^{60}$

\subsubsection{Principais diretrizes}

Por meio do Comunicado 12.746, o órgão regulador estabeleceu alguns referenciais importantes para o mercado sobre a implementação de Basiléia II no país. Sobre essas diretrizes, é relevante destacar que:

- as recomendações contidas nos pilares 2 e 3 serão aplicadas a todas as instituições do mercado nacional;

- não serão utilizados os ratings divulgados pelas agências de classificação de risco para fins de apuração dos requerimentos de capital;

- para a maioria das instituições será aplicada uma abordagem padrão simplificada;

- às instituições de maior porte será facultada a utilização de abordagens com base em sistemas internos de classificação de risco;

- as abordagens com base em modelos internos para risco de crédito serão adotadas de maneira gradativa, inicialmente sendo feita a autorização para a abordagem básica e somente em oportunidade posterior para a abordagem avançada;

- as regras e critérios para instituições de capital nacional e para as de capital estrangeiro serão as mesmas.

Sobre esses aspectos ressalta o caráter facultativo, e não obrigatório, das abordagens com base em modelos internos, por reconhecer implicitamente que nem todas as instituições podem estar aptas ou interessadas em investir na utilização dessas abordagens. Essa abordagem difere de alguns outros países, que têm optado por obrigar suas instituições mais complexas a observar as abordagens com base em modelos internos.

\footnotetext{
${ }^{59}$ Facultada a aplicação de fator equivalente à média dos FPR aplicáveis às operações integrantes da carteira do fundo.

${ }^{60}$ A norma elenca os instrumentos mitigadores e as características requeridas para garantir a efetiva redução do risco.
} 
Além disso, ao tratar da igualdade de condições entre instituições nacionais e estrangeiras, adotou-se a ausência de tratamento diferenciado quanto aos requisitos e exigências para validação de sistemas internos de classificação de risco de crédito, risco de mercado e risco operacional.

O efeito dessa declaração implica que, para uma instituição de capital estrangeiro, não basta ter seus modelos validados e aprovados pelo regulador onde está localizada sua matriz. Se tal instituição desejar utilizar seus modelos de mensuração de risco para fins de alocação de capital no Brasil, tais modelos deverão ser validados e aprovados localmente, o que leva à necessidade de discussão desse processo de validação e de aprovação pelo órgão supervisor brasileiro. 


\title{
5 AMBIENTE REGULATÓRIO BRASILEIRO PARA RISCO DE CRÉDITO
}

\subsection{Mensuração do risco de crédito: importância e regulamentação}

Para discutir o processo de validação e da aprovação de modelos internos pelo BACEN, é necessário fazê-lo considerando o ambiente regulatório brasileiro. Assim, essa análise tem o objetivo de, reconstituindo a evolução do ambiente e da norma, compreender as semelhanças e diferenças com o quadro delineado por Basiléia II, permitindo, desse modo, discutir as questões relativas à aprovação de modelos internos pelo órgão supervisor, com base na experiência brasileira.

Quanto ao foco específico no risco de crédito, justifica-o o próprio diagnóstico do Comitê da Basiléia:

\begin{abstract}
"Apesar das instituições financeiras terem enfrentado dificuldades ao longo dos anos por diversas razões, as causas principais de problemas bancários mais graves continuam a ser diretamente relacionadas ao relaxamento nos padrões de crédito para devedores e contrapartes, à fragilidades na gerência de risco da carteira, ou a uma falta da atenção às mudanças em circunstâncias econômicas ou outras que podem conduzir a uma deterioração no risco de crédito da carteira de tomadores de um banco. Esta experiência é comum tanto em países do G-10, como de países não pertencentes ao G-10." ${ }^{61}$ (BCBS, 2000, p.5)
\end{abstract}

O Comitê, ao apontar as soluções para tais problemas, realça a importância da adequada identificação, mensuração, monitoramento e controle de risco de crédito:

“[...] a exposição a risco de crédito continua a ser a principal fonte de problemas dos bancos no mundo inteiro [...]. Os bancos devem ter uma consciência afiada da necessidade de identificar, medir, monitorar e controlar o risco de crédito, bem como de se assegurarem que mantêm o capital adequado suficiente à cobertura desses riscos e que são adequadamente compensados por esses riscos incorridos". 62 (BCBS, 2000, p.5)

\footnotetext{
61 "While financial institutions have faced difficulties over the years for a multitude of reasons, the major cause of serious banking problems continues to be directly related to lax credit standards for borrowers and counterparties, poor portfolio risk management, or a lak of attention to changes in economic or other circumstances that can lead to a deterioration in the credit standing of a bank's counterparties. This experience is common in both $G-10$ and non-G-10 countries."

62 “(...) exposure to credit risk continues to be the leading source of problems in banks world-wide (...). Banks should have a keen awareness of the need to identify, measure, monitor and control credit risk as well as to determine that they hold adequate capital against these risks and that they are adequately compensated for risks incurred."
} 
No Brasil, debater a respeito de identificação, mensuração, monitoramento e controle de risco de crédito, portanto tratar de métodos e modelos de avaliação de risco de crédito com enfoque no ambiente normativo, significa discutir e analisar a principal norma atualmente vigente que regulamenta o assunto no país: a Resolução CMN 2.682/99, emitida pelo Conselho Monetário Nacional em 21 de dezembro de 1999 (Anexo A).

Entretanto, se o objetivo também consiste em entender as características do mercado de crédito nacional, significa também traçar uma linha evolutiva das normas brasileiras sobre o tema, o que leva à necessidade de retroceder ao normativo imediatamente anterior, a Resolução CMN 1.748/90, de 30 de agosto de 1990 (Anexo B), e também a outra norma importante naquele momento, a Resolução CMN 1.559/88, de 22 de dezembro de 1988..

\subsection{Histórico recente do mercado brasileiro de crédito}

\subsubsection{Mercado de crédito no período de inflação alta}

As Resoluções CMN 1.559/88 e 1.748/90 foram emitidas num momento em que o país vivenciava ainda um ambiente de inflação extremamente elevada.

Tal situação mascarava ineficiências significativas das instituições financeiras do sistema bancário brasileiro mediante os ganhos propiciados pelo floating (GARCIA, 2002, p.56). Também o BIS (2001, p.6), ao tratar dos elevados custos operacionais dos bancos latinoamericanos, associou essas ineficiências ao floating, por gerar lucros fáceis e pouca pressão para redução de custos.

O floating pode ser entendido como os recursos que os depositantes deixavam sem movimentação em suas contas-correntes não remuneradas ou ainda os recursos em trânsito, decorrentes de transferências entre praças ou entre instituições ou, ainda, do prazo entre o recolhimento de tributos e seu respectivo repasse aos tesouros federal, estaduais e municipais, entre outras situações assemelhadas. Por representarem disponibilidade de recursos sem a necessidade de remunerá-los, o floating gerava receitas financeiras para as instituições bancárias, receitas essas tão mais vultosas quanto maior fosse a inflação do período. 
Durante a década de oitenta e até a implantação do Plano Real, mais especificamente até a conversão da URV - Unidade Real de Valor - na nova moeda, o real, a inflação apresentavase elevada, explicando a magnitude dos ganhos propiciados pelo floating, bem como o grau de desestímulo que essa situação causava às demais atividades bancárias que não propiciassem esse tipo de ganho.

Decorrência desse contexto, o mercado de crédito apresentava-se pouco desenvolvido, com os bancos apresentando áreas de crédito com estruturas inadequadas, bem como critérios de concessão e controles deficientes (PANDELÓ JR., 2000, p.9; ROCHA, 2001, p.11). Um dos fatores determinantes para tal situação era o baixo nível de incentivo às instituições financeiras para que operassem nesse mercado quando havia, em contrapartida, o ganho de baixo custo e mínimo risco advindo do floating, conforme afirma Garcia (2002, p.56):

\footnotetext{
"Nesse contexto, as carteiras de crédito eram relativamente pouco desenvolvidas, e não desempenhavam papel estratégico dentro das instituições. Não havia, portanto, incentivo ao desenvolvimento ou utilização de ferramentas de gerenciamento de risco de crédito mais sofisticadas"
}

Assim, pela ausência de incentivos relevantes, as operações de crédito realizadas pelas instituições financeiras consistiam principalmente naquelas determinadas pela legislação, ${ }^{63}$ como crédito imobiliário e crédito rural, ou então nas operações com grandes empresas, com baixo risco de crédito e propiciando grande movimentação de recursos. Ou seja, salvo no caso do crédito corporativo, no crédito predominavam modalidades de aplicação obrigatória e com taxas de juros definidas na legislação ou nas normas vigentes.

Proporcionalmente pouco se operava com o varejo bancário no segmento de taxas livres, salvo produtos simples, tradicionais e de alta rentabilidade, como cheque especial e crédito pessoal, para pessoas físicas, e descontos de duplicatas para pessoas jurídicas de menor porte. O conceito de "seletividade", advindo do próprio arcabouço normativo ${ }^{64}$ e representando a capacidade de separar os bons elementos dentro de um grupo potencial de tomadores de recursos, era implantado na prática de modo distorcido.

\footnotetext{
${ }^{63}$ Decorrentes da destinação obrigatória de recursos da caderneta de poupança e dos depósitos à vista, conforme a fonte dos recursos e a natureza da instituição.

${ }^{64}$ Resolução CMN 1.559/88, inciso IX.
} 
A idéia de seletividade resultava na concessão do crédito bancário apenas aos melhores clientes, uma elite de pessoas jurídicas e físicas com elevado grau de formalidade, renda e bens. Desse modo, o crédito bancário era acessível apenas às poucas empresas que pudessem apurar balanços e balancetes e apresentar demonstração de resultado lucrativa, e às escassas pessoas físicas que detivessem empregos formais, com comprovação de renda e, principalmente, bens para oferecer em garantia.

Para compor o quadro histórico, ressalte-se que o financiamento de veículos, apresentava pouca oferta de crédito a taxas e prazos razoáveis levando o próprio mercado brasileiro a criar, à margem do sistema bancário, mecanismos para suprir a necessidade do cidadão comum que desejasse adquirir um veículo pagando-o parceladamente, mas que não possuísse renda comprovada ou que não estivesse disposto a pagar taxas de juros demasiadamente elevadas. Resultado dessa situação foi o crescimento de um tipo de atividade empresarial: o consórcio para aquisição de veículos, depois estendido à aquisição de outros bens.

Muitas vezes administrado pela própria empresa produtora do bem, empresa essa que podia ser uma montadora de veículos ou mesmo um fabricante de bens duráveis como geladeiras, fogões e assemelhados, o consórcio representou o meio encontrado para escoar a produção de bens de consumo duráveis em uma economia com mecanismos insuficientes de financiamento dentro do sistema bancário tradicional.

As distorções da economia inflacionária também afetaram o sistema financeiro, conforme exposto. Caracterizaram esse período do Sistema Financeiro Nacional - SFN não apenas a dependência do floating, mas também sua conseqüência mais imediata: o pouco apetite para risco de crédito. Como resultado, o sistema bancário do início da década de noventa era um mercado que apresentava pouco ou nenhum incentivo para a implantação de mecanismos mais sofisticados para gestão do risco de crédito (GARCIA, 2002, p.56).

A gestão do risco de crédito, naquele contexto, se dava em duas frentes: na análise de crédito pré-concessão e na constituição de garantias. Grande parte da literatura da época destinada ao treinamento de pessoal nessa área focalizava essas duas frentes.

A análise de crédito conservadora e minuciosa propiciava que as operações de crédito fossem de boa qualidade. A qualidade da carteira de crédito era assegurada na entrada das operações, 
através da seletividade dos clientes e de diversas exigências quanto a garantias. Recusavam-se as operações que apresentassem indicativos maiores de risco ou que não pudessem oferecer as garantias exigidas, uma vez que sempre haveria à disposição a alternativa de aplicar os recursos com baixo risco no mercado interfinanceiro.

\subsubsection{A Resolução 1559/88}

Essa aversão ao risco de crédito era referendada pelo espírito das próprias normas da época, como se percebe na Resolução CMN 1.559/88, que preconizava no seu inciso IX:

"IX - É vedado às instituições financeiras:

a) realizar operações que não atendam aos princípios de seletividade, garantia, liquidez e diversificação de riscos; ${ }^{65}$

b) renovar empréstimos com a incorporação de juros e encargos de transação anterior, ressalvados os casos de composição de créditos de difícil ou duvidosa liquidação;

c) admitir saques além dos limites em contas de empréstimos ou a descoberto em contas de depósitos;

d) realizar operações com clientes que possuam restrições cadastrais ou sem ficha cadastral atualizada;

e) realizar operações com clientes emitentes de cheques sem a necessária provisão de fundos; e

f) conceder crédito ou adiantamento sem a constituição de um título de crédito adequado, representativo da dívida."

Note-se que, exceção feita ao item "b)", todos os demais tópicos tratavam de evitar o ingresso de operações de alto risco na carteira de crédito. Entretanto, caso essas barreiras de entrada fossem insuficientes e alguma das operações admitidas na carteira se tornasse inadimplente, as garantias assegurariam a recuperação dos créditos.

A depender do tipo de bem ou direito envolvido, a morosidade e imprevisibilidade do sistema judicial poderiam não assegurar sua realização em prazo razoável, ou mesmo em prazo algum. Na execução judicial das garantias, além da possibilidade de inúmeros recursos legais protelatórios, também não era raro que os juízes decidissem em favor dos réus, por considerálos parte economicamente mais fraca, ainda que estivessem cumpridos todos os requisitos legais para a expropriação em favor dos credores.

65 Grifo nosso. 
Tal situação, a propósito, pouco se modificou, uma vez que parte dos juízes brasileiros considera que fazer justiça social faz parte de sua missão primordial, sobrepondo-se inclusive a garantir o cumprimento de contratos, conforme Pinheiro (2005, p.280). O autor expõe essa incerteza jurídica e seus efeitos, ao comentar pesquisas empíricas de Sadek (1995) e de Vianna et al. (1997) sobre a forma de pensar dos juizes brasileiros:

\begin{abstract}
"Esses trabalhos revelam que o magistrado brasileiro se vê como responsável por promover a mudança social e em particular reduzir as desigualdades sociais, dispondo-se com freqüência a ignorar não apenas os contratos, mas também as leis na busca desse objetivo. [...] Um resultado importante dessa pesquisa é que a não-neutralidade do magistrado, que dá origem a decisões viesadas ou com pouca previsibilidade, pode ser um problema do ponto de vista da economia tão importante quanto a morosidade"
\end{abstract}

No gerenciamento de crédito, o foco principal, tanto do ponto de vista da prática dos agentes do SFN quanto das normas, estava no controle de admissão e na recuperação de créditos, ambos tratados individualmente, caso a caso. Os mecanismos de controle interno, como as auditorias internas e as travas em sistemas informatizados, voltavam-se ao controle operação a operação.

Pouco enfoque era dado ao monitoramento da carteira como um conjunto ou ao monitoramento dos créditos durante o seu período de vigência, após a concessão e antes que houvesse inadimplência. Após a admissão, os créditos eram tratados como uma massa que se subdividia em créditos normais e créditos em atraso, sendo esses últimos os que recebiam algum grau de acompanhamento. O monitoramento preventivo pós-concessão, ou seja, o acompanhamento dos créditos e da carteira, era pouco relevante quando se tratava do monitoramento da carteira como um conjunto de ativos.

Dos controles com foco na carteira de crédito, destacava-se a obrigatoriedade de diversificação das aplicações. Exigia-se, conforme os incisos I e II da Resolução CMN 1.559/88, que no máximo 30\% (trinta porcento) do patrimônio líquido de uma instituição financeira estivesse comprometido com um único cliente e, também, que os dez maiores clientes não poderiam ser, em conjunto, responsáveis por mais que $30 \%$ (trinta porcento) das suas operações ativas. ${ }^{66}$

\footnotetext{
${ }^{66}$ Observe-se que as exigências normativas quanto à diversificação da carteira são anteriores à edição da Resolução 1.559/88, tendo sido introduzidas na própria década de oitenta.
} 


\subsubsection{A Resolução 1.748/90}

Esse ambiente de mercado e regulatório existente quando da edição da Resolução CMN 1.748/90 influenciou tanto no seu foco normativo, quanto na forma prescritiva adotada. A referida resolução, quando de sua edição, teve por objetivo específico alterar e consolidar os critérios de provisão de operações de crédito de liquidação duvidosa, mas não se apresentou conceitualmente inovadora em relação aos normativos anteriores sobre o tema, a Resolução CMN 1.675/89, de 21 de dezembro de 1989, ou às antecessoras desta, as Resoluções CMN $1.423 / 87$ e $1.425 / 87$, respectivamente.

O contexto do mercado financeiro na década de 80 e início da década de 90 pouco se modificou no que se refere ao crédito. Os normativos da época acabaram apenas por efetuar atualizações em procedimentos, sem modificações nos conceitos de base, razão pela qual a análise do último normativo daquele período, a Resolução CMN 1.748/90, foi utilizada como referência para a apreensão desses conceitos.

Baixada pelo Conselho Monetário Nacional em 30 de agosto de 1990, a Resolução CMN 1.748/90 determinava às instituições financeiras a metodologia a ser seguida na constituição de suas provisões para operações de crédito. Segundo sintetizam Garcia (2002, p.59) e Parente (2000, p.2), essa norma definia que os créditos deveriam ser provisionados basicamente em função dos prazos de atraso e das garantias que apresentassem.

Os créditos vencidos até 60 (sessenta) dias seriam considerados créditos normais, enquanto os créditos vencidos há mais de 60 (sessenta) dias seriam considerados créditos em atraso. Os créditos em atraso deveriam ser provisionados em 20 (vinte) ou $50 \%$ (cinquenta porcento) de seu saldo contábil, sendo que no primeiro caso estariam as operações cujas garantias fossem "consideradas suficientes à cobertura do saldo devedor atualizado", enquanto que no segundo estariam aquelas operações cujas garantias não fossem consideradas suficientes à cobertura do saldo devedor. 
Créditos que permanecessem em atraso ou que não contassem com garantias deveriam ser transferidos para créditos em liquidação - CL - e integralmente provisionados. Créditos sem garantias deveriam ser transferidos diretamente para créditos em liquidação após 60 (sessenta) dias de vencidos, enquanto que os créditos em atraso com garantias insuficientes à cobertura do saldo devedor deveriam ser transferidos para CL após 180 (cento e oitenta) dias de inadimplência. Operações em atraso com garantias suficientes à cobertura do saldo devedor deveriam ser transferidas para CL e integralmente provisionadas somente após 360 (trezentos e sessenta) dias de vencidas.

Para essa regra geral acima descrita, havia algumas situações de exceção. Algumas modalidades de crédito deveriam ser provisionadas em prazos mais curtos que os 60 (sessenta) dias, variando em função tanto da modalidade de crédito quanto das garantias envolvidas. Por exemplo, Adiantamentos sobre Contratos de Câmbio - $\mathrm{ACC}^{67}$ deveriam ser transferidos para CL após 20 (vinte) dias do prazo de entrega dos documentos de exportação, enquanto os financiamentos habitacionais e repasses de agências de desenvolvimento, com prazo superior a 36 (trinta e seis) meses, poderiam ter apenas as parcelas que estivessem vencidas transferidas para créditos em atraso.

No normativo há ainda diversos detalhamentos como a previsão de que, quando da transferência de uma operação para créditos em liquidação, todas as demais obrigações do mesmo devedor, inclusive as vincendas, deveriam também ser obrigatoriamente inscritas em CL e integralmente provisionadas. Essa regra tinha aplicação facultativa apenas no caso de operações que estivessem amparadas em garantias suficientes à cobertura de seus respectivos saldos devedores atualizados.

O quadro 6, a seguir, sintetiza as regras gerais de provisionamento de crédito descritas na Resolução CMN 1.748/90. Observe-se que o conceito de risco não está presente na base conceitual da norma, sendo mencionado apenas de modo indireto no artigo que estabelece que os percentuais de provisão são definidos como os "suficientes para fazer face a perdas prováveis" (Art. $\left.9^{\circ}\right)$.

\footnotetext{
${ }^{67}$ Adiantamento sobre contrato de câmbio: modalidade de crédito em que os recursos advindos de uma exportação futura contratada são adiantados ao produtor a fim de que o mesmo possa produzir o bem a ser exportado. Essa operação é liquidada pela entrega dos documentos referentes à exportação ao banco financiador, que irá receber os recursos do banqueiro do importador, no exterior.
} 
Quadro 6 - Regras de provisionamento da Resolução 1.748/90

\begin{tabular}{|c|c|c|c|}
\hline Classificação contábil & Prazo de inadimplência & Garantias & Provisão \\
\hline Normal & Até 60 dias & Indiferente & $0 \%$ do saldo \\
\hline \multirow{2}{*}{ Atraso } & Acima de 60 e até 180 dias & Insuficientes & $20 \%$ do saldo \\
\cline { 2 - 3 } & Acima de 60 e até 360 dias & Suficientes & \multirow{2}{*}{$50 \%$ do saldo } \\
\hline \multirow{3}{*}{ Créditos em liquidação } & Acima de 60 dias & Sem garantias & \multirow{2}{*}{$100 \%$ do saldo } \\
\cline { 2 - 3 } & Acima de 180 dias & Insuficientes & \\
\cline { 2 - 3 } & Acima de 360 dias & Suficientes & \\
\hline
\end{tabular}

FONTE: Elaborado pelo autor com base na Resolução CMN 1.748/90

A metodologia adotada pode ser sintetizada da seguinte forma: duas variáveis-chave, prazo de inadimplência e grau de cobertura das garantias, eram suficientes para determinar a classificação contábil de cada crédito e o nível de provisão para cobertura das perdas prováveis. Segundo Garcia (2002, p.61), o que caracterizava essa abordagem era uma “[...] preocupação exclusivamente com aspectos formais [...] para determinação da qualidade do crédito".

A provisão estabelecida para cobertura das perdas prováveis era a forma existente para medir o risco de crédito, seguindo um modelo com quatro faixas de risco. Esse modelo distribuía as operações em uma faixa para os créditos de boa qualidade e que por isso recebiam provisão de $0 \%$ (zero porcento), duas faixas para os créditos problemáticos, com risco mais significativo de perda, como pode ser deduzido a partir dos níveis de provisões exigidos de 20 (vinte) e $50 \%$ (cinquenta porcento), e uma última faixa para os créditos com elevada probabilidade de perda e que por isso eram provisionados em $100 \%$ (cem porcento) do seu saldo contábil.

Nessa metodologia era a variável "prazo de inadimplência" que modificava a condição do crédito. A garantia era um elemento complementar associado à possibilidade de recuperação do crédito, mas não à probabilidade de haver inadimplência. Dessa forma, a garantia só passava a ter influência a partir do momento em que estava caracterizada a inadimplência por mais de 60 dias, conforme pode ser visualizado no Quadro 6. 
Ainda que a Resolução CMN 1.748/90 detalhasse em seu artigo 11 os tipos e características das garantias reconhecidas para fins de cobertura das operações, exigindo inclusive reavaliações periódicas dessas garantias, de fato, a variável chave para todo o processo era o prazo de inadimplência.

Apesar de tratar-se de variável fundamental para a maioria dos modelos de mensuração de risco, calcar todo o processo de mudança de status de risco na ocorrência de um determinado número de dias de inadimplência apresentava problemas.

Em primeiro lugar, tornava a metodologia altamente reativa, isto é, só se constatava o aumento do risco quando ele se convertera em perda provável, no momento em que o tomador do crédito, chamado a honrar seus compromissos, falhava. O uso apenas da variável inadimplência não fornecia uma medida prospectiva, que avaliasse as probabilidades futuras do evento inadimplência ocorrer, ou seja, o risco de inadimplemento, apenas constatava que a inadimplência havia acontecido.

Em segundo lugar, por se tratar de uma metodologia para fins regulatórios, tê-la calcada essencialmente na variável inadimplência ocasionava uma visão incorreta dos riscos incorridos pelos bancos, bem como a possibilidade de manipulação contábil no caso de bancos em dificuldades.

Para fins de ilustração, tome-se o caso de uma instituição financeira com carteira de crédito de alto risco, majoritariamente de curto prazo e contratação relativamente recente, com grande parte das operações ainda a vencer. Por essa norma, tal instituição financeira passaria uma imagem enganosa de solidez e baixo risco, por apresentar um nível de provisionamento desproporcionalmente baixo em relação à probabilidade de perda em sua carteira, uma vez que as provisões eram feitas apenas quando as operações venciam e, portanto, quando estava consumada a inadimplência.

Parente (2000, p.3) sintetiza esses dois problemas da norma:

"Como a determinação de provisionar estava vinculada a um atraso nas operações, o ambiente regulatório anterior acabava por não abordar o caráter estimativo previsto na definição (de provisão). Guardar relação direta com o atraso dos pagamentos acabou por não abranger a totalidade das origens do risco nas atividades de crédito. De fato, o atraso é mais que um indicativo de risco elevado; ele também é o sintoma que antecede uma perda efetiva. A vinculação 
da constituição de provisões apenas a partir do não pagamento, desobrigou o caráter prospectivo que as provisões por definição devem ter."

Outros aspectos incluíam os problemas de manipulação contábil que poderiam ocorrer, pois, conforme Garcia (2002, p.62), “[...] era comum a permanência de operações de crédito com baixas perspectivas de liquidação, muitas vezes objeto de sucessivas renegociações, em curso normal [...]." Portanto, se uma instituição estivesse com patrimônio líquido contábil próximo ao mínimo exigido e uma operação de grande valor estivesse prestes a se tornar inadimplente, bastaria prorrogá-la ou então contratar uma nova operação liquidando a anterior, o que permitia adiar para um momento posterior, ou mesmo indefinidamente, o reconhecimento da elevação do risco de crédito de operações problemáticas, com a correspondente explicitação das perdas prováveis nas provisões.

Essa possibilidade de manipulação se tornou explícita durante a crise bancária de meados da década de 90, logo após a implantação do Plano Real. A queda brusca da inflação causou uma mudança significativa no ambiente operacional dos bancos, que perderam a receita advinda do floating. Como a inflação baixou de maneira significativa, seu efeito imediato foi tornar pouco relevante o ganho financeiro propiciado pela disponibilidade de recursos sem movimentação em conta corrente ou com prazo distinto entre a arrecadação e o pagamento, como no caso do recolhimento de tributos.

A perda brusca das receitas advindas da inflação expôs a realidade operacional de diversas instituições financeiras. Muitos bancos passaram a buscar recuperar em duas frentes os ganhos perdidos: a cobrança de tarifas sobre os serviços bancários e as receitas decorrentes da concessão de crédito.

A recuperação de receitas através da concessão de crédito dependia da expansão do crédito. Naquele momento, a ampliação do crédito concentrou-se nas pessoas jurídicas, dado que para operar massificadamente com o varejo de pessoas físicas eram necessários novos sistemas de informações e controle.

Se no ambiente anterior a demanda por crédito era maior que a oferta, possibilitando aos bancos controlar a qualidade de suas carteiras pela seletividade, no novo momento a equação se invertera: muitos bancos passaram a oferecer agressivamente crédito, rebaixando o nível de exigências quanto a aspectos fundamentais à formação de carteiras de crédito de boa 
qualidade. Abertura de informações econômico-financeiras, histórico de relacionamento bancário positivo, adequada cobertura de garantias, entre outros, tiveram seu grau de exigência reduzido durante a competição que tomou conta dos bancos por seus clientes, resultando na contratação de operações com muito mais risco que as habitualmente até então concedidas.

Além disso, as taxas de juros internas foram majoradas do modo significativo no início de 1995 para conter pressões inflacionárias, causando não apenas aumento no custo do crédito, mas reduzindo a expectativa de crescimento da demanda, elevando o nível de dificuldade financeira das empresas endividadas. (PANDELÓ JR, 2000, p. 9; ROCHA, 2001, p.11)

Segundo esses autores, esse conjunto de fatores acabou por provocar uma crise bancária, ${ }^{68}$ decorrente da conjugação da perda dos ganhos propiciados pelo floating com a elevação significativa da inadimplência em operações de crédito.

A facilidade de manipulação contábil, mediante a postergação dos prazos de vencimento das operações, tornou mais complexa a administração da crise pelo órgão de supervisão. A própria norma vigente, ao basear primordialmente o cálculo de provisões em função dos prazos de atraso, portanto a partir de situações de risco instaladas, mostrou-se defasada para fins de apuração do risco efetivamente incorrido pelas instituições financeiras.

Impedida uma crise bancária sistêmica, mediante principalmente a instituição pelo governo federal do PROER - Programa de Estímulo à Reestruturação e ao Fortalecimento do $\mathrm{SFN}^{69} \mathrm{e}$ do PROES - Programa de Incentivo à Redução do Setor Público Estadual na Atividade Bancária, ${ }^{70}$ ficou patente que a Resolução CMN 1.748/90, além das fragilidades apontadas, encontrava-se conceitualmente defasada na forma de regular a mensuração de risco de crédito no SFN, conforme sintetiza Lofrano (2001, p.9):

\footnotetext{
${ }^{68}$ Nesse período, bancos tradicionais e de grande porte como Nacional, Bamerindus e Econômico sofreram intervenções ou tiveram de ser vendidos por insuficiência de liquidez, a exemplo de outras instituições menores. São citados esses casos por serem os três bancos que à época constavam entre os dez maiores do SFN por volume total de ativos, caracterizando a gravidade da crise.

${ }^{69}$ Programa estabelecido pelo governo federal para saneamento do setor bancário privado, criava condições para que instituições financeiras sólidas comprassem a parcela saudável (carteira de clientes, rede de agências, ativos de boa qualidade) de instituições problemáticas.

${ }^{70}$ Programa estabelecido pelo governo federal para saneamento e redução do segmento de bancos públicos estaduais, criava condições para a transferência desses bancos para a esfera federal para posterior privatização.
} 
"Tendo em vista o longo tempo decorrido desde a sua edição, bem como a evolução do mercado financeiro e a mudança no perfil de crédito das operações contratadas, a Resolução 1.748 apresentava-se inadequada, face ao seu enfoque retrospectivo, necessitando de reformulação"

\subsection{A Resolução CMN 2.682/99}

\subsubsection{Contexto e características gerais}

Os debates entre técnicos do Banco Central, especialistas e acadêmicos em torno de uma nova normatização sobre o tema estenderam-se principalmente ao longo de 1999 , inclusive com a adoção de consultas públicas pelo BACEN sobre o tema. Procedimento inovador à época, a versão preliminar da nova norma foi posta em audiência pública para fins de coleta de subsídios e sugestões junto aos agentes do SFN. Resultado desse "diálogo", na expressão de Garcia (2002, p.73), ao final do ano de 1999, após concluídas as consultas e discussões, o CMN baixou no dia 21 de dezembro a Resolução CMN 2.682/99, introduzindo na regulação brasileira o conceito de classificação de risco de crédito e revogando a Resolução CMN $1.748 / 90$.

Iniciando uma nova etapa em termos de filosofia de regulamentação de risco de crédito no país e pretendendo contribuir para o estabelecimento de uma cultura de gestão de crédito mais sólida (GARCIA, 2002, p.56 e 59), a nova norma passou a exigir que os bancos classificassem suas operações de crédito em função do risco que estas apresentassem (Res 2.682/99, art. $1^{\circ}$ ), estabelecendo para esse fim nove níveis distintos e crescentes de risco, denominados AA, A, B, C, D, E, F, G e H.

Para efetuar a classificação, as instituições financeiras deveriam observar não apenas aspectos relacionados às operações propriamente ditas, como prazos e garantias, mas também proceder à avaliação do risco dos devedores e seus garantidores, considerando aspectos como sua situação econômico-financeira, grau de endividamento, capacidade de geração de resultados, fluxo de caixa, setor econômico, administração e controles internos, entre outros $\left(\right.$ Res 2.682/99, art. $\left.2^{\circ}\right)$.

Foram trazidos para o ambiente normativo procedimentos de avaliação que constituíam práticas corriqueiras pelos bancos para fins de concessão de empréstimos: avaliar o cliente e 
avaliar a operação proposta. A diferença é que tais procedimentos subsidiariam não apenas a decisão de conceder ou não crédito, como até então acontecia, mas também serviriam para a apuração e diferenciação do nível de risco dos créditos que fossem concedidos.

Apesar de não ser a situação mais comum dentro do SFN, alguns bancos até mesmo dispunham de sistemas de classificação de riscos próprios e bem desenvolvidos, podendo continuar a utilizá-los adaptados à nova norma (GARCIA, 2002, p.65). Para grande parte das instituições financeiras, no entanto, o processo de adaptação ao novo normativo foi complexo, inclusive pela novidade conceitual de classificar os créditos segundo seus riscos, em contraposição à prática vigente de focalizar a avaliação e a administração das carteiras no montante de provisões constituídas.

\subsubsection{Auto-regulação na Resolução 2.682/99}

Se por um lado a norma estabeleceu que os bancos teriam que avaliar o risco do tomador de crédito e da operação, por outro lado não determinou a forma sobre como esses fatores deveriam ser combinados. No máximo, elencou elementos que deveriam ser considerados na avaliação (situação econômico-financeira, endividamento, histórico, garantias, etc). Caberia aos bancos a responsabilidade por avaliar e ponderar cada um desses elementos a seu exclusivo critério, desde que "com base em critérios consistentes e verificáveis" (Res. 2.682/99, art. $2^{\circ}$ ), a fim de apurar o risco de seus créditos.

A Resolução CMN 2.682/99 introduziu uma liberdade às instituições financeiras para modelar o risco que representou uma importante inovação nas normas de crédito brasileiras, que eram, até então, significativamente prescritivas e descritivas sobre o que poderia e o que não poderia ser realizado, sobre como deveria ser essa execução, e qual procedimento a adotar em cada possível situação.

Esse padrão existente até então era o da regulação tutelar, na expressão adotada por Carvalho (2005, p.136), da qual são emblemáticas as vedações à concessão de crédito existentes na Resolução CMN 1.559/88 ou, ainda, os critérios de provisionamento da Resolução CMN 1.748/90, totalmente objetivos e prescritivos, baseados fundamentalmente em um único 
elemento, o prazo de atraso, sem espaço para as ponderações e ressalvas características da avaliação do risco de crédito.

De fato, o que ocorre é que a Resolução CMN 2.682/99 refletiu uma tendência internacional de modificações na forma de regulamentar os sistemas financeiros, em linha com as próprias orientações do Comitê da Basiléia. Lima (2005, p.198), tratando do contexto que levou a Basiléia II, afirma que:

"Ao invés de buscar-se supervisionar e regular as mutantes posições substantivas ${ }^{71}$ de risco dos bancos, mais eficiente seria monitorar e regular os procedimento ${ }^{72} s$ adotados por estes em seus próprios cálculos de risco [...]. Essa ênfase nos processos internos foi influenciada pela necessidade de tornar as políticas de supervisão mais baseadas no risco, dado o contexto de crescente complexidade das atividades bancárias [...]".

Carvalho (2005, p.138), também tratando do contexto que levou a Basiléia II, explica que:

"[...] o abandono da perspectiva tutelar de supervisão financeira representava um rompimento com uma tradição quase secular. $\mathrm{Na}$ verdade, tudo indica que este rompimento deu-se menos pela persuasão de que se poderia confiar no mercado para tomar as precauções adequadas e muito mais pela percepção da limitação da capacidade dos reguladores em antecipar movimentos adversos por parte dos bancos e criar obstáculos adequados para detê-los. A capacidade inovadora das instituições financeiras em ambiente de desregulação e liberalização tornou a supervisão detalhista e intrusiva do século XX praticamente impossível [...]”

Assim, segue Carvalho, concluindo que:

[...] a focalização das atenções nas estratégias de risco [...] foi menos uma escolha por parte dos reguladores do que um choque de realidade com respeito às suas limitações [...] a capacidade inovadora das instituições financeiras em ambiente de desregulamentação e liberalização tornou a supervisão detalhista e intrusiva do século XX praticamente impossível".

Tal contexto levou a que mecanismos de auto-regulação de riscos pelas próprias instituições do mercado passassem a ser mais aceitos pelas autoridades de supervisão, pois:

“[...] em vez de tentar supervisionar diretamente as complexas e mutantes posições de risco dos bancos, as autoridades passaram a admitir ser mais eficaz se os reguladores e supervisores monitorassem os procedimentos adotados pelas próprias instituições em seus cálculos, estimativas e métodos de gestão de riscos e requisitos de ativos/capital." (Corazza, 2005, p.88).

\footnotetext{
${ }^{71}$ Grifo do autor

${ }^{72}$ Grifo do autor
} 
Esse contexto internacional acabou tendo influência decisiva no quadro regulatório criado pela Resolução CMN 2.682/99, pois, ao invés de apresentar uma regulamentação fechada como a norma anterior, que mediante a combinação de dois itens (o prazo de inadimplência e as garantias) determinava qual o risco a ser atribuído a cada operação, a nova norma delegava ao mercado, a cada instituição financeira, como o risco de crédito seria calculado.

Parente (2000, p.8) chama a atenção para esse último aspecto, como também o faz Garcia (2002, p.73) ao afirmar:

\footnotetext{
"Ao estabelecer apenas (os) elementos a serem considerados no processo de classificação de risco, sem determinar a estrutura a ser utilizada, o Banco Central delegou às instituições a responsabilidade pelo estabelecimento e utilização de sistemas considerados por elas coerentes, a serem avaliados pela Supervisão"
}

No entanto, essa delegação de poder trouxe novos desafios aos bancos e supervisores, pois, ainda segundo a autora:

“[...] o desafio às instituições de constituição de um sistema de classificação para fins de cumprimento de uma regulação sem o estabelecimento de regras específicas implicou também em um novo desafio à Supervisão Bancária. A verificação do cumprimento da norma não estaria associada somente à verificação burocrática de preenchimento de determinados parâmetros objetivos, mas também a consideração da adequação da metodologia."

Modificou-se de modo significativo, portanto, a natureza do processo de supervisão bancária do risco de crédito no Brasil, ao introduzir a discussão sobre metodologias e sistemas de mensuração de risco de crédito entre regulador e regulado, antecipando o aspecto mais complexo presente em Basiléia II para o regulador: a aceitação ou não de modelos internos de classificação de risco para fins de alocação de capital.

Outro aspecto da abordagem aberta adotada foi sua flexibilidade para regular um sistema financeiro complexo e heterogêneo, que apresentava e ainda apresenta múltiplas instituições com portes, culturas internas, nichos de atuação e tecnologia em crédito diversificados, além de tampouco bloquear a mensuração de risco no nível de conhecimento de uma determinada época. A forma mais aberta adotada permite absorver a maior parte da evolução na formas de modelar o risco sem tolher a capacidade de pesquisa e aplicação por parte dos bancos.

Apesar da abordagem aberta e flexível constituir aspecto central da nova norma, a delegação de poder ao mercado não foi completa, uma vez que o CMN determinou algumas linhas gerais da sistemática de classificação de risco. 
Estabeleceu, por exemplo, que fossem avaliados o risco do devedor e o risco da operação, apontou os quesitos mínimos que deveriam ser considerados para esses itens, estabeleceu prazos para a revisão periódica das classificações, provisionamentos em função dos atrasos e outros procedimentos específicos a serem observados, alguns dos quais tem a função de atuar como moderadores à liberdade delegada às instituições financeiras.

\subsubsection{Moderadores à auto-regulação}

Se por um lado a norma delegava ao mercado a liberdade para modelar o risco de crédito, por outro essa delegação não era total pela introdução de três elementos com uma função moderadora: a sistemática de provisionamento, o prazo de inadimplência e a possibilidade de ação do órgão de supervisão.

\subsubsection{Sistemática de provisionamento e comparabilidade externa}

O primeiro elemento moderador presente na Resolução CMN 2.682/99 foi a sistemática de provisionamento adotada. No seu artigo $6^{\circ}$, previa-se que, para o total de operações classificadas em determinado nível de risco, deveria ser constituído um total de provisão correspondente a um percentual específico do saldo dessas operações para fazer face a perdas prováveis na realização dos créditos.

Créditos que fossem classificados no nível de risco A deveriam ter provisionado no mínimo 0,5\% do seu saldo. Créditos classificados no nível B teriam provisão obrigatória mínima de $1 \%$ do seu saldo. E assim sucessivamente, conforme o Quadro 7, a seguir, sintetiza a relação entre os níveis de risco e os correspondentes níveis mínimos de provisão exigidos. 
Quadro 7 - Classificações e provisões da Resolução 2.682/99

\begin{tabular}{|c|c|}
\hline Classificação de risco & Provisão mínima \\
\hline AA & $0 \%$ \\
\hline A & $0,5 \%$ \\
\hline B & $1 \%$ \\
\hline C & $3 \%$ \\
\hline D & $10 \%$ \\
\hline E & $30 \%$ \\
\hline F & $50 \%$ \\
\hline G & $70 \%$ \\
\hline H & $100 \%$ \\
\hline
\end{tabular}

Fonte: Elaborado pelo autor com base na Resolução 2.682/99

Do ponto de vista contábil, a provisão destina-se à cobertura de perdas prováveis, tendo um caráter estimativo. A associação de cada classificação com um certo nível de provisão cria um efeito moderador pelo fato de que se um determinado modelo de classificação atribuísse uma expectativa de perda a um determinado crédito, tem-se que essa expectativa de perda indicaria qual o nível de provisão que a ele deveria ser associado e, portanto, em qual classificação de risco o mesmo se enquadraria. Não haveria lógica em outro procedimento, pois não haveria sentido se as perdas esperadas fossem diferentes da provisão constituída, dado o conceito contábil desta última.

Esse raciocínio resulta que, apesar da norma estar redigida de modo que uma determinada classificação implica um determinado nível de provisionamento, na prática a lógica subjacente é a inversa: a partir da provisão necessária é que se determina qual a classificação a ser atribuída. Esse fato decorre de que grande parte dos modelos de classificação são construídos em função da probabilidade de inadimplência (ANTONOV, 2002, p.25), a qual relaciona-se diretamente às perdas esperadas e, portanto, às provisões.

Assim, tem-se que um determinado nível de perda esperada implica provisão em proporção equivalente e esta, por sua vez, está associada a uma única classificação de risco. Desse modo, a própria adequação da classificação passada pode ser verificada a partir justamente da comparação entre a perda esperada atribuída a cada crédito individualmente e a perda efetiva, eventualmente corrigindo-se os critérios adotados para as futuras operações. 
Vem dessa relação entre as provisões e a perdas esperadas o primeiro elemento moderador da norma: independentemente do modelo adotado e de seu grau de complexidade, a cada estimativa de perda corresponde uma única classificação de risco semelhante para todos os agentes do mercado financeiro, uniformizando os conceitos e facilitando a comparabilidade. Facilita também a aplicação da disciplina por parte do órgão de supervisão e também por parte do mercado, dado que as instituições são obrigadas a publicar diversas informações sobre suas carteiras nas notas explicativas às suas demonstrações financeiras.

Apesar de terem sido determinados nove níveis de risco com faixas específicas de provisionamento, isso não constitui impedimento à evolução para modelos com maior granularidade. ${ }^{73}$ Se considerarem necessário a um adequado gerenciamento de sua carteira, as instituições financeiras não encontram impedimento na norma para que utilizem internamente níveis adicionais de risco, subdividindo aqueles pré-definidos.

Além disso, a sistemática adotada acabou por balizar a prática de mercado também quanto ao que representa cada um dos níveis de risco. Por exemplo, créditos de nível D são reconhecidos pelo próprio mercado como operações problemáticas, mas com chances relevantes de retornarem à normalidade, enquanto créditos de nível $\mathrm{E}$ a $\mathrm{H}$ referem-se a operações com probabilidade relevante de perda. Créditos de nível AA a C são tratados como componentes de carteiras normais, de boa qualidade. Essa padronização de entendimentos, que acaba por facilitar a própria autodisciplina de mercado, é decorrência dos percentuais de provisão atribuídos a cada uma das faixas de risco.

Não haveria lógica financeira em conceder uma operação nova cujo risco atribuído, após considerados risco de cliente e da operação, seja nível D, obrigando a um provisionamento imediato de no mínimo dez porcento do saldo liberado. Salvo raras exceções, faz mais sentido entender uma operação nível D como sendo um crédito que, concedido anteriormente em melhores condições, portanto com melhor classificação, deteriorou-se e passou a apresentar uma perda esperada igual ou superior a dez porcento.

\footnotetext{
${ }^{73}$ Modelos com mais níveis de risco.
} 
No caso dos níveis E e acima, a obrigatoriedade de constituição de um mínimo de trinta porcento de provisão representa uma expectativa de perda relevante, daí se tratarem de créditos com probabilidade de inadimplência tendendo a 1, sendo as perdas esperadas medidas em função da expectativa de recuperação do crédito. Em contrapartida, as operações com classificação AA até $\mathrm{C}$, por representarem uma baixa proporção de provisionamento, acabam sendo reconhecidas pelo mercado como as carteiras normais das instituições financeiras.

A discussão do parágrafo anterior e da própria sistemática de classificação pode ser feita com base na equação de risco EL = PD x LGD x EAD, em que o saldo contábil de um crédito pode ser considerado uma aproximação para a exposição EAD, mesma forma de tratamento da provisão para risco de crédito como sendo uma aproximação para as perdas esperadas EL.

A Resolução 2.682/99 tem base conceitual relacionada ao conceito de perdas esperadas, absorvendo os conceitos tanto de probabilidade de inadimplência, quanto de recuperação de crédito, o que foi vislumbrado também por Garcia (2002, p.70). Se a expectativa de recuperação de crédito não estivesse também implícita, seria o caso de questionar qual a significância estatística de uma probabilidade de inadimplência de 30\% (trinta porcento), correspondente ao nível de risco E. Ou de 70\% (setenta porcento), correspondente ao nível de risco G. Esses níveis de risco com provisão igual ou superior a 30\% (trinta porcento) só fazem sentido se for considerado que a norma também admite a consideração da expectativa de recuperação do crédito, semelhantemente à equação das perdas esperadas.

\subsubsection{Função dos prazos de inadimplência}

O segundo elemento moderador à liberdade das instituições financeiras em modelarem seus riscos de crédito para fins regulatórios refere-se ao prazo de inadimplência, que a Resolução CMN 2.682/99 manteve como um elemento relevante na apuração do risco, mas de um modo distinto em relação à regra anterior.

Enquanto que na Resolução CMN 1.748/90 o prazo de inadimplência era o fator que modificava a condição de risco de uma operação, no novo normativo o prazo de inadimplência apresenta-se como sendo um limitador importante ao "livre arbítrio" das instituições financeiras nas suas modelagens de risco. 
No artigo $4^{\circ}$ da Resolução CMN 2.682/99, estabelece-se a classificação mínima admitida para créditos que se apresentassem em atraso. Operações vencidas há mais de 60 dias, podem, na melhor das hipóteses, serem classificadas no nível de risco D. Se estiverem vencidas há mais de 90 dias, a melhor classificação possível será mais rigorosa: nível E, e assim sucessivamente, limitando em função desses prazos o grau de liberdade dos bancos em atribuir a classificação de risco de seus créditos, conforme o Quadro 8.

Quadro 8 - Classificações em função dos prazos de atraso

\begin{tabular}{|l|c|}
\hline \multicolumn{1}{|c|}{ Prazo de atraso } & Classificação de risco mínima \\
\hline Até 14 dias & Não determinada \\
\hline Entre 15 e 30 dias & $\mathrm{B}$ \\
\hline Entre 31 e 60 dias & $\mathrm{D}$ \\
\hline Entre 61 e 90 dias & $\mathrm{E}$ \\
\hline Entre 91 e 120 dias & $\mathrm{F}$ \\
\hline Entre 121 e 150 dias & $\mathrm{G}$ \\
\hline Entre 151 e 180 dias & $\mathrm{H}$ \\
\hline Acima de 180 dias & \\
\hline
\end{tabular}

Fonte: Elaborado pelo autor com base na Resolução 2.682/99

A norma estimula que os bancos sejam proativos em reconhecer seus riscos, mesmo os que não se encontram em atraso, fazendo-o segundo seus próprios critérios. Mas se esses critérios próprios se revelarem ineficazes, o critério do prazo de inadimplência funciona como um limitador, um teto máximo para o grau de liberdade concedido às instituições financeiras.

A experiência vivenciada pelo autor na área de supervisão bancária do Banco Central mostrou que nos bancos que trabalhavam com modelos internos de classificação de risco para tomada de decisão, a mudança de foco regulatório foi rapidamente compreendida e incorporada aos processos, enquanto que nas instituições que não os utilizavam, ou utilizavam de maneira incipiente, a nova norma foi absorvida por algum tempo mais como uma mudança nos prazos de atraso para fins de provisionamento do que como uma mudança conceitual na forma de medir o risco de crédito. 
Sobre os prazos de atraso, a Resolução CMN 2.697/00, de 24 de fevereiro de 2000, estabeleceu que as operações contratadas com clientes cujo risco total seja de no máximo R \$ $50.000,00$ (cinquenta mil reais) podem ter seu risco avaliado de duas formas: exclusivamente em função dos prazos de atraso, hipótese prevista na Resolução CMN 2.682/99, ou então em função de modelo interno de classificação de risco, sem observância obrigatória dos referidos prazos de atraso.

Nesse detalhe da norma está uma questão relevante que é a eliminação do efeito moderador dos prazos de atraso para as instituições financeiras que adotam modelos internos de classificação de risco para os créditos até R \$ 50.000,00 (cinquenta mil). Esse teto normativo abrange parte relevante das operações das carteiras dos bancos e do varejo de crédito bancário, elevando o grau de autonomia das instituições financeiras na definição de suas classificações de risco e, portanto, de suas provisões para risco de crédito.

\subsubsection{Poder discricionário da supervisão}

Caso os dois elementos anteriores, a comparabilidade externa e os prazos de atraso, sejam insuficientes para compensar eventuais desvios na utilização da liberdade para mensurar e classificar o risco de crédito, há um terceiro elemento presente na norma que permite corrigir esses desvios eventuais: a intervenção direta do órgão de supervisão, ao qual se concedem algumas prerrogativas descritas no artigo $13^{\circ}$ da Resolução CMN 2.682/99.

Segundo o texto da norma:

\footnotetext{
"Art. 13. O Banco Central do Brasil poderá baixar normas complementares necessárias ao cumprimento do disposto nesta Resolução, bem como determinar:

I - reclassificação de operações com base nos critérios estabelecidos nesta Resolução, nos níveis de risco de que trata o art. $1^{\circ}$;

II - provisionamento adicional, em função da responsabilidade do devedor junto ao Sistema Financeiro Nacional;

III - providências saneadoras a serem adotadas pelas instituições, com vistas a assegurar a sua liquidez e adequada estrutura patrimonial, inclusive na forma de alocação de capital para operações de classificação considerada inadequada;

IV - alteração dos critérios de classificação de créditos, de contabilização e de constituição de provisão;

$\mathrm{V}$ - teor das informações e notas explicativas constantes das demonstrações financeiras;

VI - procedimentos e controles a serem adotados pelas instituições."
} 
Os incisos III, V e VI apareciam com redação semelhante na norma anterior (Resolução CMN 1.748/91), enquanto os incisos I, II e IV foram introduzidos pela Resolução CMN 2.682/99.

A intervenção do órgão supervisor pode se dar com base em qualquer um dos incisos acima. No caso dos incisos I e II, a intervenção se dá no nível de uma classificação específica de um crédito ou conjunto destes. A reclassificação pode ser determinada se não tiverem sido observados os critérios previstos na própria norma (inciso I) ou se o devedor do crédito apresentar um endividamento de alto risco junto a outras instituições do SFN (inciso II).

No caso do inciso III, também se prevê a intervenção no nível da operação com classificação de risco inadequada, mas o escopo é mais amplo permitindo ao BACEN a exigência de providências saneadoras a fim de manter os níveis de liquidez e adequação de capital, semelhantemente aos incisos IV, V e VI, cujo tipo de intervenção se dá ao nível dos procedimentos e controles (VI), transparência (V) ou mesmo da própria sistemática de classificação de risco e provisionamento (IV).

O processo introduzido pela Resolução CMN 2.682/99 cria ao lado da livre classificação de riscos uma hierarquia dos fatores de moderação. Em primeiro lugar, a pressão dos pares (outros bancos) e demais partes interessadas (financiadores, acionistas) decorrente da comparabilidade das classificações e da obrigatoriedade de maior grau de disclosure (transparência). Em segundo lugar, os limites máximos para a classificação em função dos prazos de atraso. E em terceiro lugar, caso os dois elementos anteriores não sejam suficientes para produzir um sistema adequado de classificação de riscos, a possibilidade de intervenção da supervisão bancária, invalidando o modelo adotado.

\subsubsection{Validação de modelos na Resolução 2.682 e em Basiléia II}

No parágrafo anterior, mencionou-se a possibilidade de invalidação de um modelo de risco, apesar do termo não constar explicitamente da norma. A previsão normativa de impor a alteração de critérios de classificação representa a recusa pelo BACEN dos critérios adotados pela instituição financeira, ou seja, a invalidação do modelo ocasionando sua substituição, parcial ou total. Portanto, se o órgão de supervisão, durante seu processo de fiscalização em 
risco de crédito, não apontar problemas ou correções a serem efetuadas na sistemática de classificação de uma determinada instituição, ou seja, se não invalidá-la explicitamente, temse de fato uma validação tácita do modelo adotado.

Diferentemente de Basiléia II, o que se tem no quadro regulatório atual é uma situação de validação a posteriori, pela não invalidação, em que os bancos e demais instituições são autorizados pela norma a usar seus modelos próprios, sem necessidade de autorização ou validação a priori.

Sob esse aspecto a Resolução CMN 2.682/99 é mais ousada que Basiléia II no que tange à auto-regulação, pois introduz e aplica a idéia de modelo interno sem validação prévia e para todas as instituições do SFN, ainda que, tanto uma quanto outra possuam elementos com a função de moderar a liberdade das instituições financeiras.

No caso da norma brasileira, o uso do modelo interno influencia a adequação de capital, conforme ocorre com Basiléia II, como também tem efeitos de natureza contábil por conta das provisões regulamentares decorrentes das classificações de risco atribuídas.

Essa é uma discussão fundamental, pois, para o órgão regulador, parte da complexidade de Basiléia II no que tange ao risco de crédito apresenta-se na validação dos modelos internos utilizados pelos bancos para fins de alocação de capital para suas perdas inesperadas.

Um equívoco comum sobre essa questão, decorrente da excessiva ênfase da literatura nos seus aspectos estatísticos, é o entendimento de que validação de modelo de risco implica somente na revisão dos processos estatísticos de criação e manutenção destes modelos. Isso é apenas parcialmente verdadeiro por representar somente parte do que seria um processo completo e efetivo de validação.

O contexto do novo acordo é o de aproximar o capital regulatório do capital econômico calculado pelos bancos. Daí que os modelos a serem validados são aqueles utilizados pelas instituições financeiras no seu dia-a-dia, aprovadas pelo próprio teste de uso ao longo do tempo, constituindo-se em ferramentas efetivas de gestão pela alta administração, e não um processo matemático desenvolvido especificamente para apresentação ao órgão regulador. Dessa forma, a questão crucial nos processos de validação compreende não apenas a 
avaliação da efetividade dos sistemas de classificação de riscos internos, mas também de todo o processo de gestão e controle de risco de crédito nos quais esses sistemas se inserem.

\subsubsection{Gestão de risco de crédito, transparência e outros aspectos comuns}

Muitos conceitos relativos ao gerenciamento de risco de crédito fundamentais para a aplicação das abordagens IRB aparecem também na Resolução CMN 2.682/99.

Um exemplo é a questão do monitoramento de crédito, mediante revisão periódica do risco, que constitui boa prática bancária referendada internacionalmente (BIS, 2000) e passa a ser também uma exigência normativa. Não se determina às instituições como deve ser o processo de revisão, mas sim a obrigatoriedade de que o mesmo seja incorporado aos seus procedimentos.

$\mathrm{O}$ artigo $4^{\circ}$, que trata da revisão da classificação em função do atraso, estabelece um prazo máximo para a reavaliação do risco de cada crédito, aspecto também previsto nas abordagens IRB de Basiléia II. Na norma brasileira esse prazo é de normalmente um ano a partir da última avaliação, podendo ser reduzido a seis meses, se tratar-se de risco de cliente ou grupo econômico cuja somatória supere 5\% (cinco por cento) do PLA - patrimônio líquido ajustado da instituição financeira.

A norma passa a exigir que políticas e procedimentos para concessão e classificação de créditos sejam documentados de forma a "evidenciar, pelo menos, o tipo e os níveis de risco que a instituição financeira se dispõe a administrar, os requerimentos mínimos exigidos para a concessão de empréstimos e o processo de autorização". A Resolução CMN 2.554/98, que trata dos mecanismos de controle interno nas instituições financeiras, abrange questões dessa natureza de maneira mais genérica, ao passo que a Resolução CMN 2.682/99 destaca a importância de que a documentação das políticas e procedimentos de crédito é, no mínimo, aspecto fundamental para a gestão e controle de riscos dessa natureza. Em Basiléia II, conforme discutido no capítulo anterior, exige-se também formalização de políticas e processos, além da documentação relativa aos sistemas de classificação, o que pode levar à necessidade de edição pelo CMN de um normativo específico tratando mais detalhadamente da gestão do risco de crédito. 
No quesito transparência, é exigido das instituições financeiras um grau maior de abertura quanto ao risco incorrido em suas carteiras de crédito. Passa a ser obrigatório que estas publiquem, em notas explicativas às suas demonstrações financeiras, informações detalhadas de suas carteiras de crédito, sendo exigida divulgação, no mínimo, dos dados que constam do Quadro 9.

Quadro 9 - Exigências de divulgação de informações da Res. 2.682/99

\begin{tabular}{|c|c|}
\hline Informação & Segregação \\
\hline \multirow{2}{*}{ Distribuição das operações } & Tipo de cliente \\
\cline { 2 - 2 } & Atividade econômica \\
\cline { 2 - 2 } & Prazos de vencimento \\
\cline { 2 - 2 } & Nível de risco ${ }^{74}$ \\
\hline \multirow{2}{*}{ Valores por exercício } & Operações renegociadas \\
\cline { 2 - 2 } & Lançadas contra prejuízo \\
\cline { 2 - 2 } & Recuperadas de prejuízo \\
\hline
\end{tabular}

Fonte: Elaborado pelo autor com base nas Resoluções 2.682/99 e 2.697/00.

A questão da transparência é definida como uma prática saudável para o gerenciamento do risco de crédito (BIS,2000), como também é um dos elementos fundamentais do Pilar 3 de Basiléia II, contribuindo para maximizar a ação disciplinadora do próprio mercado.

Ainda sobre a questão da transparência e disciplina de mercado, a Resolução CMN 2.682/99 passa a envolver de maneira direta os auditores independentes no processo de classificação de riscos, ao determinar que estes elaborem "[...] relatório circunstanciado de revisão dos critérios adotados pela instituição quanto à classificação nos níveis de risco e de avaliação de provisionamento registrado nas demonstrações financeiras". Trata-se de uma providência que se relaciona também aos mecanismos de moderação anteriormente citados, ao inserir uma terceira parte para assegurar a qualidade dos processos de classificação de riscos.

Para assegurar a qualidade dos modelos de risco e, por conseguinte, aos dados tornados públicos, o artigo $8^{\circ}$ da Resolução CMN 2.682/99 busca limitar o espaço para manipulações

\footnotetext{
${ }^{74}$ A cada nível de risco devem ser segregadas as operações em curso normal com atraso inferiora 15 dias e os créditos vencidos com atraso igual ou superior a 15 dias.
} 
de natureza contábil, ao estabelecer alguns critérios específicos para as operações renegociadas. Essa preocupação com os créditos renegociados tem por origem a manipulação dos créditos em atraso na época da Resolução CMN 1.748/90, uma vez que a renegociação sucessiva de operações foi um mecanismo usado por instituições financeiras para burlar os prazos para provisionamento definidos naquela norma.

Considerando que na norma atual os prazos de inadimplemento continuam a ter uma função importante no esquema de regulação, justifica-se a preocupação do CMN em manter um tratamento mais restrito para créditos com essa característica, preocupando-se em elaborar uma definição regulamentar para os créditos renegociados, exigindo ainda a divulgação de operações com essas características em notas explicativas às demonstrações contábeis.

Outra similaridade entre a Resolução CMN 2.682/99 e Basiléia II, refere-se à conceituação ampla de risco de crédito, não se restringindo apenas ao crédito efetivamente contratado e desembolsado, mas também incluindo operações extrapatrimoniais, a exemplo de avais, garantias prestadas, cartas de crédito e derivativos, no rol de operações a terem seu risco obrigatoriamente mensurado. Nesse caso, a semelhança é parcial, uma vez que Basiléia II prevê uma abordagem mais ampla, onde a mensuração de risco de crédito deve abranger todas as operações que representem riscos dessa natureza, incluindo títulos e valores mobiliários e até mesmo títulos públicos.

\subsubsection{Da regulação tutelar à auto-regulação}

Essa questão da conceituação do risco de crédito nos leva a destacar outra mudança, ocorrida na passagem da Resolução CMN 1.748/90 para a Resolução CMN 2.682/99. Enquanto a primeira norma determinava individualmente quais as contas contábeis do balanço patrimonial deveriam compor a base de cálculo da provisão para risco de crédito, na norma atual não há essa preocupação. $\mathrm{O}$ artigo $14^{\circ}$ da Resolução CMN 2.682/99 cita que todas as suas disposições se aplicam "também às operações de arrendamento mercantil e a outras operações com características de concessão de crédito" ${ }^{75}$, sem no entanto preocupar-se em apresentar qualquer definição mais específica.

\footnotetext{
${ }^{75}$ Grifo nosso.
} 
Essa mudança é emblemática do abandono do enfoque tutelar anterior, em que se tentava prever todas as situações possíveis, pré-estabelecendo os procedimentos a serem observados. A nova norma adotou uma abordagem baseada em princípios de auto-regulação pelo mercado, conjugando flexibilidade com responsabilidade e reconhecendo a incapacidade do regulador definir a priori todas as situações em que há risco de crédito, bem como a forma de mensurá-lo e os procedimentos a serem adotados em cada situação.

Isso evidencia não apenas a mudança de abordagem entre essas duas normas como ilustra o ponto que vimos buscando demonstrar com a exegese dos dois normativos brasileiros e de Basiléia II: que a distância entre a Resolução 1.748/90 e a Resolução 2.682/99, tanto em termos conceituais, quanto de abordagem, é muito mais ampla que a distância a ser percorrida entre esta última e o quadro regulatório proposto por Basiléia II. E que a complexidade deste último concentra-se na implementação prática, mas não na novidade dos conceitos introduzidos.

\subsection{Quadro comparativo das Resoluções 1.784/90 e 2.682/99 a Basiléia II}

O Quadro 10, apresentado a seguir, permite visualizar os conceitos que foram sendo incorporados à norma brasileira na passagem da Resolução CMN 1.748/99 para a Resolução CMN 2.682/99. Permite ainda perceber quais aspectos de Basiléia II estão contemplados, quais estão contemplados parcialmente e quais representam conceitos novos que devem ser incorporados à norma.

Essa análise é concluída com a sumarização dos aspectos discutidos neste capítulo e no anterior, sintetizando a evolução da norma brasileira comparada ao quadro regulatório desenhado por Basiléia II e demonstrando de forma sistematizada a questão das diferenças conceituais entre os três cenários. 
Quadro 10 - Análise comparativa - Resoluções CMN 1.748/90 e 2.682/99 e Basiléia II

\begin{tabular}{|c|c|c|c|}
\hline TÓPICO & $\begin{array}{c}\text { RESOLUÇÃO 1.748/90 } \\
\text { - cenário anterior - }\end{array}$ & $\begin{array}{c}\text { RESOLUÇÃO 2.682/99 } \\
\text { - cenário atual - }\end{array}$ & $\begin{array}{l}\text { BASILÉIA II - IRB } \\
\text { - próximo cenário - }\end{array}$ \\
\hline Abordagem & Tutelar & $\begin{array}{l}\text { Auto-regulação, com } \\
\text { limitações }\end{array}$ & $\begin{array}{l}\text { Auto-regulação, com } \\
\text { limitações }\end{array}$ \\
\hline Foco normativo & $\begin{array}{l}\text { Controle de atrasos e } \\
\text { garantias para constituição } \\
\text { de provisão }\end{array}$ & $\begin{array}{l}\text { Sistemas internos de } \\
\text { avaliação de risco para } \\
\text { constituição de provisão }\end{array}$ & $\begin{array}{l}\text { Sistemas internos de } \\
\text { avaliação de risco para } \\
\text { alocação de capital }\end{array}$ \\
\hline Dados de entrada & $\begin{array}{l}\text { Prazo de atraso } \\
\text { Prazo da operação } \\
\text { Tipo de garantia } \\
\text { Saldo contábil }\end{array}$ & $\begin{array}{l}\text { Risco cliente } \\
\text { Risco operação (linha de } \\
\text { crédito e garantias) } \\
\text { Saldo contábil } \\
\text { Prazos de atraso }\end{array}$ & $\begin{array}{l}\text { PD associada ao cliente } \\
\text { LGD associada à operação } \\
\text { (linha de crédito e garantias) } \\
\text { EAD associada ao valor da } \\
\text { operação na inadimplência } \\
\text { M associada ao prazo da } \\
\text { operação }\end{array}$ \\
\hline $\begin{array}{l}\text { Exigências quanto } \\
\text { à gestão de crédito }\end{array}$ & $\begin{array}{l}\text { Restrições a empréstimos } \\
\text { (RES.1559) }\end{array}$ & $\begin{array}{l}\text { Processo de gestão } \\
\text { documentado e avaliado } \\
\text { pela supervisão }\end{array}$ & $\begin{array}{l}\text { Processo de gestão } \\
\text { documentado e avaliado pela } \\
\text { supervisão, expressamente } \\
\text { aceito na validação dos } \\
\text { modelos internos }\end{array}$ \\
\hline $\begin{array}{l}\text { Discricionariedade } \\
\text { da supervisão }\end{array}$ & $\begin{array}{l}\text { Determinação de } \\
\text { provisionar operações } \\
\text { Possibilidade de } \\
\text { determinação de } \\
\text { procedimentos e controles } \\
\text { Exigências de divulgação } \\
\text { (notas explicativas) }\end{array}$ & $\begin{array}{l}\text { Determinação de } \\
\text { provisionar operações } \\
\text { Alteração nos sistemas de } \\
\text { classificação } \\
\text { Possibilidade de } \\
\text { determinação de } \\
\text { procedimentos e controles } \\
\text { Exigências de divulgação } \\
\text { (notas explicativas) }\end{array}$ & $\begin{array}{l}\text { Interferência na gestão, nos } \\
\text { controles e sistemas de } \\
\text { classificação através dos } \\
\text { processos de habilitação para } \\
\text { IRB. } \\
\text { Possibilidade de cobrança de } \\
\text { um coeficiente adicional de } \\
\text { capital em caso de problemas } \\
\text { solucionáveis nos modelos. }\end{array}$ \\
\hline
\end{tabular}




\begin{tabular}{|c|c|c|c|}
\hline $\begin{array}{l}\text { Uso regulatório dos } \\
\text { modelos internos }\end{array}$ & Sem previsão & $\begin{array}{l}\text { Provisionamento (perdas } \\
\text { esperadas) }\end{array}$ & $\begin{array}{l}\text { Alocação de capital (perdas } \\
\text { esperadas e inesperadas) }\end{array}$ \\
\hline $\begin{array}{l}\text { Condições para uso } \\
\text { regulatório de } \\
\text { modelos internos }\end{array}$ & Sem previsão & $\begin{array}{l}\text { Sem condição prévia. } \\
\text { Não rejeição específica } \\
\text { pela supervisão ao modelo } \\
\text { utilizado. }\end{array}$ & $\begin{array}{l}\text { Exigências específicas para o } \\
\text { uso do modelo. } \\
\text { Aprovação prévia pela } \\
\text { supervisão } \\
\text { Avaliação contínua }\end{array}$ \\
\hline $\begin{array}{l}\text { Abrangência do } \\
\text { uso regulatório de } \\
\text { modelos internos }\end{array}$ & Sem previsão & $\begin{array}{l}\text { Obrigatório para todas } \\
\text { instituições financeiras. }\end{array}$ & $\begin{array}{l}\text { Permitido apenas para } \\
\text { instituições complexas e com } \\
\text { dados estatisticamente } \\
\text { relevantes. }\end{array}$ \\
\hline $\begin{array}{l}\text { Escopo da } \\
\text { mensuração do } \\
\text { risco de crédito } \\
\text { para fins } \\
\text { regulatórios }\end{array}$ & $\begin{array}{l}\text { Operações de crédito } \\
\text { contabilizadas nos ativos }\end{array}$ & $\begin{array}{l}\text { Operações de crédito } \\
\text { contabilizadas nos ativos e } \\
\text { "off-balance" (avais, } \\
\text { fianças, cartas de crédito) } \\
\text { Normativamente, toda } \\
\text { operação com característica } \\
\text { de concessão de crédito } \\
\text { Na prática, apenas } \\
\text { operações tradicionais e } \\
\text { garantias }\end{array}$ & $\begin{array}{l}\text { Risco de crédito de todas as } \\
\text { operações, inclusive títulos e } \\
\text { valores mobiliários, } \\
\text { soberanos, crédito } \\
\text { interbancário, ações }\end{array}$ \\
\hline $\begin{array}{l}\text { Tratamento } \\
\text { específico para } \\
\text { varejo }\end{array}$ & Sem previsão & $\begin{array}{l}\text { Definição implícita: } \\
\text { operações até R\$ } 50 \text { mil. } \\
\text { Permite modelos internos } \\
\text { sem observar os limitadores } \\
\text { dos prazos de atraso }\end{array}$ & $\begin{array}{l}\text { Definição explícita: } \\
\text { operações tratadas como } \\
\text { grupos homogêneos (pools) } \\
\text { Modelam PD, LGD e EAD } \\
\text { conjuntamente. }\end{array}$ \\
\hline
\end{tabular}




\begin{tabular}{|c|c|c|c|}
\hline $\begin{array}{l}\text { Efeito do prazo de } \\
\text { inadimplência }\end{array}$ & $\begin{array}{l}\text { Principal determinante na } \\
\text { constituição de provisão. }\end{array}$ & $\begin{array}{l}\text { Determinante na } \\
\text { constituição da provisão } \\
\text { apenas dos créditos } \\
\text { vencidos. } \\
\text { Importante limitador da } \\
\text { margem de arbítrio dos } \\
\text { bancos na modelagem de } \\
\text { risco. }\end{array}$ & $\begin{array}{l}\text { Importante limitador da } \\
\text { margem de arbítrio, mas sem } \\
\text { ser fundamental à modelagem } \\
\text { de risco }\end{array}$ \\
\hline $\begin{array}{l}\text { Definição do prazo } \\
\text { de inadimplência }\end{array}$ & $\begin{array}{l}0 \text { a } 360 \text { dias, a depender da } \\
\text { combinação de prazo e } \\
\text { garantia }\end{array}$ & $\begin{array}{l}60 \text { dias (risco D) } \\
\text { A partir de } 15 \text { dias há } \\
\text { decaimento da classificação } \\
\text { de riscos }\end{array}$ & $\begin{array}{l}60 \text { ou } 90 \text { dias, a critério de } \\
\text { cada supervisor nacional }\end{array}$ \\
\hline Mitigação de riscos & $\begin{array}{l}\text { Tratamento rudimentar de } \\
\text { garantias decorrente da } \\
\text { divisão em grandes grupos } \\
\text { pela natureza jurídica, sem } \\
\text { considerações quanto à } \\
\text { liquidez e recuperação. }\end{array}$ & $\begin{array}{l}\text { Garantias computadas no } \\
\text { risco-operação } \\
\text { Foco em suficiência e } \\
\text { liquidez }\end{array}$ & $\begin{array}{l}\text { Estrutura complexa de CRM } \\
\text { Diversas categorias e } \\
\text { instrumentos } \\
\text { Proporcional ao nível de } \\
\text { cobertura da operação }\end{array}$ \\
\hline $\begin{array}{l}\text { Subdivisão das } \\
\text { garantias por tipo }\end{array}$ & $\begin{array}{l}\text { Reais } \\
\text { Fidejussórias } \\
\text { Inexistentes }\end{array}$ & $\begin{array}{l}\text { Não define. } \\
\text { Exige avaliação em função } \\
\text { da suficiência para } \\
\text { cobertura dos riscos e da } \\
\text { liquidez. }\end{array}$ & $\begin{array}{l}\text { Várias faixas de ponderação } \\
\text { de risco em função dos } \\
\text { possíveis tipos }\end{array}$ \\
\hline Divulgação & Sem previsão específica & $\begin{array}{l}\text { Composição detalhada da } \\
\text { carteira por tipo de cliente, } \\
\text { segmento, vencimento, } \\
\text { renegociações e prejuízos. }\end{array}$ & $\begin{array}{l}\text { Grande volume de } \\
\text { informações qualitativas e } \\
\text { quantitativas } \\
\text { Dados detalhados sobre } \\
\text { carteiras, modelos, sistemas } \\
\text { de classificação, históricos de } \\
\text { perdas, políticas de crédito e } \\
\text { risco, entre outras. }\end{array}$ \\
\hline
\end{tabular}

FONTE: Elaborado pelo autor com base nas Res. 1.748/90, 2.682/99 e BCBS, 2004b. 


\section{LEVANTAMENTO DE CAMPO}

\subsection{Aspectos da pesquisa}

Para avaliar e possibilitar as conclusões apresentadas na análise do quadro regulatório, foi realizado um levantamento de natureza exploratória, com base em entrevistas semiestruturadas, junto a executivos seniores do mercado financeiro nacional envolvidos com a adoção de Basiléia II para risco de crédito no Brasil.

Nesse levantamento, teve-se por objetivo capturar a percepção desses agentes de mercado, relativamente ao risco de crédito, quanto ao quadro normativo atual e a evolução necessária desse quadro. Também procurou-se obter a visão dos entrevistados sobre quais adaptações deveriam ser realizadas nas características originais de Basiléia II para adequá-lo às características do mercado brasileiro, bem como sobre os desafios, percorridos e a percorrer, para a sua implantação no Brasil. Por fim, buscou-se obter dos entrevistados uma avaliação da relação custo-benefício desse processo de adaptação.

Considerando que, conforme exposto ao longo deste trabalho, as questões mais complexas e inovadoras relativas ao risco de crédito referem-se à adoção das abordagens baseadas em modelos internos (IRB), a pesquisa ficou restrita a executivos ligados às áreas de crédito e gestão de riscos, atuando nas principais instituições financeiras que pretendem ou podem vir a adotar as abordagens IRB de Basiléia II.

Desse modo, foram entrevistados executivos ligados às áreas de gestão de riscos de onze bancos que pretendem adotar tais enfoques em sua atuação no Brasil, sendo três bancos estatais, quatro bancos privados de capital nacional e quatro bancos privados de capital estrangeiro. Conforme compromisso de confidencialidade assumido com os entrevistados (Anexo C), não são identificados neste trabalho os bancos ou os respondentes, sendo feita referência apenas quanto à origem do capital (público, privado nacional, privado estrangeiro) quando tal informação for relevante para a compreensão de algum ponto específico.

As entrevistas foram realizadas na modalidade semi-estruturada, explorando um roteiro de questões, com foco nos aspectos ligados ao risco de crédito. 


\subsection{Roteiro de entrevista}

1) Quais as principais restrições e dificuldades existentes para implementar Basiléia II no Brasil?

2) Quais as principais adaptações que necessitam ser feitas a Basiléia II para que seja implementado de modo consistente com as características do mercado brasileiro?

3) Qual a visão sobre a interação entre a Resolução CMN 2682/99 e Basiléia II e as principais modificações necessárias na regulação brasileira?

4) Qual o papel da estrutura instituída pela Resolução 2682 para o processo de modelagem de risco e validação de modelos internos, no ambiente de Basiléia II?

5) No que se refere ao órgão regulador, quais os principais desafios e dificuldades que têm sido encontrados na preparação para a adoção de Basiléia II?

6) O que foi feito, o que está em andamento e o que falta fazer na sua instituição financeira para adotar as abordagens avançadas de Basiléia II para risco de crédito?

7) Quais as vantagens e desvantagens da adoção das abordagens avançadas? Os custos compensam?

Cabe registrar que as questões 1, 3 e 4, além de seu caráter exploratório, têm o propósito de comprovar a validade ou não de hipóteses apresentadas ao longo deste trabalho, enquanto as demais têm caráter exploratório e portanto mais descritivo do que analítico. A seguir são comentados os resultados obtidos com as entrevistas.

\subsection{Restrições e dificuldades para implantar Basiléia II}

As principais dificuldades apontadas pelos entrevistados concentram-se nas questões relativas à estruturação das bases de dados nas condições exigidas por Basiléia II e à mudança cultural necessária para viabilizar todas as mudanças necessárias à sua implementação.

A estruturação das bases de dados, tanto no que se refere à coleta dos dados quanto à reestruturação de sistemas de informação, foi apontada de modo unânime pelos respondentes como a questão operacionalmente mais complexa e que tem demandado os maiores esforços e 
investimentos por parte das instituições financeiras. A complexidade desse trabalho envolve a captura de inúmeros dados, muitos de modo retroativo, sendo que algumas dessas informações até existem, mas não eram tratadas de modo organizado institucionalmente, enquanto outras nem sequer eram coletados pelas instituições.

Segundo os entrevistados, esse trabalho se torna ainda mais complexo ao se tratar da coleta de dados para estimação da LGD, pois envolve a apuração de custos administrativos e judiciais com a recuperação de crédito, variáveis críticas no cálculo daquele parâmetro mas que na grande maioria dos casos não eram tratadas segundo critérios internamente uniformes pelas instituições, isso quando havia tratamento específico.

Em relação à LGD, deve-se destacar que há um segundo elemento crítico em seu cômputo, o qual refere-se à taxa de desconto a ser utilizada para trazer a valor presente o montante estimado de recuperação. A existência de uma taxa mais elevada em relação aos padrões internacionais, derivada de um elevado custo de oportunidade local, combinada com um processo de recuperação de créditos longo, decorrente da morosidade da justiça, pode resultar num valor presente de recuperação muito baixo, levando portanto a uma LGD elevada e trazendo pouco impacto efetivo no cômputo das perdas esperadas e inesperadas. O problema não estaria nesse fato em si, dado que essa é a realidade de mercado, mas na incômoda percepção de que a estruturação das bases de dados para cálculo da LGD tem sido a parte do processo que mais tem demandado esforços e investimentos e que talvez agregue proporcionalmente pouca informação em termos do risco efetivo.

Apontado com preocupação por dois entrevistados, um ponto sobre as bases de dados utilizadas para a modelagem relaciona-se à mudança estrutural pela qual tem passado o SFN. Os respondentes destacaram que nos últimos anos a relação Crédito/PIB tem crescido de modo constante e consistente, tendo saído de um piso mínimo de 25 (vinte e cinco) e atingido $33 \%$ (trinta e três porcento), com perspectivas de continuar se elevando. Esses entrevistados avaliam que se trata de uma mudança estrutural ainda em curso e que é devida à redução da disponibilidade de títulos públicos e de seus spreads, levando às instituições a operar mais agressivamente no crédito, atingindo tanto segmentos sócio-econômicos de maior risco, quanto aumentando exposições em segmentos que vinham sendo atendidos e, ainda, reduzindo os spreads cobrados em diversas modalidades de crédito. 
Considerando que as bases de dados têm sido construídas considerando horizontes temporais de cinco a sete anos passados, os entrevistados manifestaram preocupação se esses dados mais antigos continuariam a ser representativos do risco de crédito presente nas carteiras atuais e se, com isso, faria sentido manter-se a exigência, no caso brasileiro, de que tais bases fossem construídas considerando uma perspectiva histórica tão longa quanto as exigidas por Basiléia II.

Outro ponto que foi apontado de modo unânime pelos entrevistados referiu-se à necessidade de mudança cultural interna às instituições para que haja uma implementação eficaz das abordagens baseadas em modelos internos. Alguns dos entrevistados destacaram que Basiléia II não se trata de uma questão meramente regulatória, mas fundamentalmente de mudança nos processos de gestão e na própria forma de fazer negócios, uma vez que possibilita formas muito mais precisas de mensurar a relação entre risco e retorno de suas atividades e, portanto, de atribuir preço de modo especifico a cada uma de suas operações e de distribuir incentivos internos de maneira mais correta. Seria portanto uma questão ligada à competitividade, contribuindo ativamente para cobrança correta dos spreads proporcionalmente ao risco e para o incremento da eficiência nos processos internos. Importaria menos, segundo os respondentes, o eventual benefício de um consumo menor de capital do que a própria possibilidade de ter uma visão mais concreta e precisa dos riscos incorridos, propiciando um melhor nível de gestão dos mesmos.

Segundo a maioria dos entrevistados, tal conscientização teria ocorrido de fato nos níveis da alta administração da instituição em que atuam, resultando num grau relevante de prioridade para os projetos ligados a Basiléia II, tanto em nível orçamentário quanto de envolvimento desses administradores. Questionados adicionalmente sobre sua visão a respeito desse assunto em relação à situação média dos demais bancos com potencial para a adoção de abordagens IRB, alguns entrevistados manifestaram dúvidas quanto ao efetivo envolvimento e compreensão por parte da administração a respeito da magnitude das implicações de Basiléia II na forma de medir e gerir os riscos e, portanto, na própria forma de gestão do negócio bancário. Não houve qualquer citação nominal de concorrentes, apenas a manifestação de uma preocupação relevante sobre quanto essa mudança cultural estaria disseminada de fato no 
SFN. Em dois casos foram percebidos indicativos ${ }^{76}$ de que a implementação dos modelos internos de Basiléia II ainda seria tratada apenas como uma questão principalmente regulatória e restrita à área de responsável pelo controle de riscos.

Além disso, em algumas instituições, apesar do efetivo envolvimento da alta administração e de sua compreensão quanto aos benefícios em termos de governança, ainda haveria alguma dificuldade de que essa visão se difundisse por todas as áreas, especialmente áreas de negócios e produtos diretamente afetadas pelas mudanças nos processos internos resultantes de uma precificação mais ajustada ao risco.

As questões relativas à mudança cultural e a necessidade de envolvimento de fato da alta administração propiciaram questionamentos adicionais sobre como se dariam tais processos em bancos públicos, dada a rotatativade de seus dirigentes de nível estatutário. ${ }^{77}$ Um dos entrevistados declarou que tais mudanças sempre têm algum impacto, mas o que assegura a continuidade da cultura organizacional, garantindo portanto que esse processo de mudança cultural não seja revertido a cada substituição da direção, é que o primeiro nível hierárquico abaixo dos dirigentes estatutários sempre tem sido ocupado por funcionários de carreira seniores, com um grau elevado de comprometimento com a instituição e com participação ativa na construção da própria cultura organizacional interna.

Assim, projetos de maturação longa e que interferem na cultura da empresa, tanto quanto dela dependem para sua adequada implementação, tem suas condições de implementação asseguradas justamente por essa parcela do corpo funcional, por meio de sua interação direta com os dirigentes estatutários recém chegados à instituição e pela interação destes com seus pares mais antigos. Esse processo fica prejudicado quando não ocorre essa interação, normalmente em decorrência da substituição concomitante da totalidade ou da maioria dos dirigentes e dos membros do Conselho de Administração, algo não incomum em finais de mandatos de governos, ocasionando prejuízos a esse processo de adaptação cultural justamente no nível da alta administração.

\footnotetext{
76 Prazos de implantação irrealistas face à complexidade do processo e ao estágio interno atual, pouca compreensão das dificuldades do processo de adaptação, atribuição excessiva de importância à aquisição de solução de tecnologia como condição para solução dessas dificuldades e/ou projeto Basiléia II aparentemente ainda confinado à área de riscos.

${ }^{77}$ Rotatividade normalmente atrelada ao prazo de mandato dos governantes.
} 
A modelagem de risco não foi apontada como sendo a dificuldade mais relevante por qualquer dos entrevistados. A questão da modelagem foi citada por poucos entrevistados, no contexto de situar as três etapas do processo: estruturação da base de dados, modelagem do risco em função dos dados coletados e uso dos modelos de modo efetivo na gestão do risco de crédito e na precificação dos negócios. Esses entrevistados, como os demais, destacaram como mais desafiadores a estruturação dos dados, juntamente com as questões tecnológicas associadas, e o uso dos modelos de modo institucional, que trata da mudança cultural acima discutida.

Aspectos pontuais relativos à modelagem de risco foram citados por entrevistados, mas tratando de dificuldades mais específicas, muitas delas relacionadas à ausência ou dificuldade de coleta de dados importantes, principalmente no que se refere ao cômputo da LGD ou à consideração dos efeitos dos ciclos econômicos. Foi apontada como uma questão importante a dificuldade de modelagem de risco para carteiras corporate, dada a pouca relevância estatística dos eventos de default, sendo que as soluções tem caminhado para o uso de bases de informações externas, como birôs de risco ou, no caso de bancos internacionais, pelo agrupamento da carteira não apenas em nível país, mas nos níveis regional ou global.

Essa constatação contribui para validar a hipótese inicial deste trabalho, de que parte das dificuldades para adaptação a Basiléia II estaria nas questões de natureza operacional. Essas dificulades estariam menos associadas ao processo de modelagem de PD, LGD e EAD que na coleta e estruturação dos dados necessários para sua estimação dentro dos parâmetros definidos pelo Comitê da Basiléia.

A quase totalidade dos entrevistados afirmou que suas instituições vinham fazendo uso de modelos que consideram esses parâmetros em suas carteiras, ainda que não atendendo totalmente às exigências previstas por Basiléia II, notadamente quanto ao nível de informação exigido para o cálculo da LGD e aos prazos de cinco a sete anos para as bases de dados.

Outro ponto destacado neste trabalho também se confirmou relevante na visão dos entrevistados: que os modelos utilizados para fins de cômputo do capital próprio sejam aqueles efetivamente utilizados pela instituição no gerenciamento efetivo do dia-a-dia dos seus negócios, o use test, conforme expressão utilizada pelo próprio Comitê da Basiléia. Caso contrário perder-se-ia a essência conceitual de Basiléia II de aproximar o capital regulamentar 
do capital econômico e, portanto, sua eficácia como marco regulatório. Os entrevistados, ao destacarem o desafio da mudança cultural interna, trataram fundamentalmente da mesma questão, ao realçarem que Basiléia II não tem caráter meramente regulatório, mas relaciona-se principalmente com a adoção das melhores práticas de gestão de riscos e com formas mais precisas de medir, incentivar e aperfeiçoar o desempenho organizacional.

\subsection{Principais adaptações para implementação no Brasil}

Em relação às necessárias adaptações de Basiléia II para o Brasil, alguns aspectos foram mencionados de modo quase unânime pelos entrevistados, como alguns critérios adotados pelo Banco Central nas normas recentemente divulgadas para a abordagem padronizada. Foram citados especificamente os critérios para definir os créditos de varejo, bem como os fatores de ponderação atribuídos aos mitigadores de risco de crédito.

No caso do crédito ao varejo, manifestou-se uma preocupação com a inadequação para o mercado local quanto à definição do Comitê da Basiléia: exposições até um milhão de euros poderiam ser tratadas como crédito de varejo, valor unanimemente considerado excessivo para o mercado nacional. No entanto, segundo a visão da totalidade dos entrevistados, o BACEN teria sido conservador ao estabelecer os critérios para enquadramento em varejo: exposições até $\mathrm{R} \$ 400.000,00$ (quatrocentos mil reais) ou empresas com faturamento até $\mathrm{R}$ \$ 2.400.000,00 (dois milhões e quatrocentos mil reais) por ano.

Segundo os respondentes, essa definição estaria fora dos parâmetros internos da grande maioria das instituições, especialmente para os créditos destinados a pessoas jurídicas. Não haveria incompatibilidade relevante em relação às pessoas físicas mas, no caso de créditos a empresas, os bancos teriam seus processos internos seguindo os modelos de concessão e administração de varejo ${ }^{78}$ para créditos a empresas com faturamento significativamente superior ao nível estabelecido, chegando em alguns casos a até $\mathrm{R} \$ 10.000 .000,00$ (dez milhões de reais) ao ano. ${ }^{79}$

\footnotetext{
${ }^{78}$ Crédito baseado fundamentalmente em escores (credit scoring e behaviour scoring), gestão corporativa em nível de carteira e não por cliente individual.

${ }^{79}$ Alguns bancos reconheceram que há diferentes níveis de tratamento interno dentro do segmento denominado varejo, sendo que, nos casos em que essa questão foi discutida de modo específico, as carteiras empresariais que são geridas de forma efetivamente similar ao varejo destinado às pessoas físicas, segundo as características
} 
Essa questão ocasionou algumas preocupações com os critérios a serem adotados nas abordagens baseadas em modelos internos. Os entrevistados reconhecem ser excessivo o valor adotado pelo Comitê, mas, se vier a ser adotado um critério significativamente mais conservador que a prática do mercado local, a conseqüência poderia ser um desvirtuamento do conceito de aproximação do capital regulatório do capital econômico, dado que os processos internos continuarão a ser processos de gestão de varejo para parte significativa dessa carteira, ainda que esta não seja reconhecida dessa forma pelos reguladores para fins do cômputo do capital. Citou-se que tal decisão teria ainda dois efeitos: prejuízo ao crédito à pequena empresa e à gestão interna dos bancos, uma vez que para essa parte da carteira haveria dois processos distintos para o cômputo do capital, um para fins regulatórios e outro para fins de gestão propriamente dita.

No caso dos mitigadores de risco de crédito, houve várias menções aos fatores de ponderação adotados pelo regulador na abordagem padronizada, sendo o caso mais citado o do financiamento com garantia de veículos. Segundo os entrevistados que abordaram essa questão, o mercado de veículos apresenta excelente liquidez e eficiência na formação e divulgação de preços, além de processo de recuperação ágil para os padrões nacionais, superior ao crédito imobiliário. Esses aspectos poderiam justificar um tratamento positivamente diferenciado para exposições com mitigadores desse tipo, com fatores de ponderação pelo menos semelhantes aos exigidos para o crédito imobiliário.

Houve várias menções críticas ao fato do BACEN não ter dado tratamento diferenciado às operações contratadas com base em recebíveis, ${ }^{80}$ dado essas operações terem, na avaliação das instituições, tradição consolidada no SFN no sentido de serem créditos de baixo risco, com histórico de reduzidas perdas efetivas.

Outra menção comum foi quanto aos fatores de ponderação atribuídos ao crédito consignado, que, segundo alguns entrevistados, poderia ter um fator de ponderação mais leve que o atribuído ao varejo na abordagem padronizada (75\%). A estrutura da operação, bem como o

descritas na nota anterior, limtam-se às empresas com faturamento anual até aproximadamente $\mathrm{R} \$ 4.000 .000,00$ (quatro milhões).

${ }^{80}$ Duplicatas, cheques, faturas de cartão de crédito. 
baixo histórico de perdas, justificariam um tratamento mais compatível com o baixo risco da operação. ${ }^{81}$

Ao mencionar aspectos concorrenciais, dois entrevistados destacaram que, no futuro a adoção das abordagens baseadas em modelos internos tende a criar uma condição competitiva muito diferenciada entre os bancos grandes e pequenos e que seria importante que o Banco Central atentasse para esse aspecto, buscando criar condições para que esse diferencial não fosse fator de exclusão do mercado para bancos de menor porte.

Outro fator ligado à concorrência mencionado foi a exigência de capital de $11 \%$ (onze porcento), acima dos $8 \%$ (oito porcento) exigidos na maioria dos países desenvolvidos, que, segundo os entrevistados, tem efeito negativo nas condições competitivas de bancos de capital nacional e que, dadas as mudanças qualitativas no ocorridas no SFN nos últimos anos, poderia ser objeto de revisão pelo Banco Central.

Um aspecto que gera uma indicação para estudos futuros por pesquisadores desse tema foi uma menção específica quanto à necessidade de adaptação da equação para cálculo das perdas inesperadas por risco de crédito, que foi definida fundamentalmente com base nos mercados do G-10. Foi apontado que essa equação resultaria em exigência de capital desproporcionalmente elevada para créditos com perfil assemelhado àqueles concedidos às médias empresas, o que poderia prejudicar o desenvolvimento destas últimas, pois tal efeito não teria qualquer correlação direta com os riscos efetivos, mas sim com políticas específicas do G-10 de direcionamento incentivado de crédito.

A pergunta apurou que as maiores discussões do mercado ainda se concentram nas questões que foram decididas pelo regulador para a abordagem padronizada e, principalmente, se o que foi decidido determinará ou não um padrão de entendimento do órgão regulador para as abordagens avançadas. Segundo um dos entrevistados, a expectativa é que "na adaptação de Basiléia II ao Brasil, o BACEN seja mais conservador com o que no Brasil for pior que no

\footnotetext{
${ }^{81}$ Um contra-argumento está no fato de que se trata de uma modalidade relativamente nova, em que os possíveis fatores de risco ainda não estão devidamente avaliados. Apenas a título de exemplo desses potenciais fatores de risco, notícias recentes dão conta de que alguns governos estaduais tem debitado as prestações no salário dos funcionários, mas não tem repassado tais recursos aos bancos credores, renegociando tais débitos em prazos de até 12 meses (Valor Econômico, 22/10/2007).
} 
ambiente internacional, mas que também não seja tão conservador quando ocorrer a situação inversa".

\subsection{Visão sobre a Resolução CMN 2.682/99 e Basiléia II}

Em relação à Resolução CMN 2.682/99, a maioria dos entrevistados destacou seu papel importante na introdução de modo generalizado de uma visão de risco na avaliação do crédito, reconhecendo a importância da exigência regulatória para a disseminação da prática de avaliar e atribuir ratings às suas exposições de crédito.

Nesse sentido, o ponto principal foi o conceito de visualização dos riscos desde o início da operação e não no momento da inadimplência, possibilitando a realização da provisão com base no risco e não mais apenas em fatos constatados, criando dessa forma as pré-condições culturais e tecnológicas ${ }^{82}$ necessárias para a implantação de Basiléia II. Por essa razão, conforme destacado por parte dos respondentes, a norma estaria alinhada com o conceito de perda esperada de Basiléia II, com algumas ressalvas relacionadas ao tratamento dos créditos em atraso.

Alguns entrevistados, no entanto, não reconheceram inicialmente a idéia de que na base conceitual da norma as provisões estariam associadas às perdas esperadas segundo a definição de $\mathrm{EL}=\mathrm{PD} X \mathrm{X}$ LGD X EAD. Questionados a respeito, o principal ponto apontado como justificativa para essa visão foi o tratamento dos créditos em atraso.

O tratamento dos créditos em atraso, ao determinar percentuais crescentes de provisionamento que desconsideram qualquer perspectiva de recuperação, portanto a LGD, tornam o cálculo da provisão mais conservador que as perdas esperadas. Haveria ainda um efeito de dupla contagem, pois, quando a carteira é avaliada e todos o créditos estão ainda vincendos, a provisão é feita em função da perda esperada para aquele conjunto. Sabe-se que uma proporção esperada da carteira redundará em perdas, mas, no momento da avaliação inicial

\footnotetext{
${ }^{82} \mathrm{Na}$ questão tecnológica, houve destaque também ao papel da Central de Risco de Crédito do Banco Central CRC, especialmente após sua ampliação, rebatizada de Sistema de Informações de Crédito - SCR, que teria sido fundamental para a uma grande reestruturação das bases de dados internas, permitindo um sensível desenvolvimento dos modelos de mensuração de risco de crédito.
} 
ainda não é possível identificar individualmente em quais créditos essa perda se manifestará. Quando há o atraso, no entanto, o tratamento da norma funciona na prática como sendo a segregação de tais créditos da carteira para adoção de um tratamento mais conservador (provisão integral em 180 dias), sendo mantido o mesmo tratamento para o restante da carteira que permaneceu em normalidade, daí a dupla contagem.

Esse aspecto da Resolução torna sua abordagem para as provisões efetivamente mais conservadora que a estimação da perda esperada, mas trata-se de um aspecto pontual que não invalida o fato de que, para os créditos vincendos, o tratamento adotado é efetivamente o de perdas esperadas, com o que concordou a maioria dos entrevistados.

Esse ponto da resolução foi o que motivou a principal sugestão para a evolução da regulação: que a norma para a provisão seja mais convergente ainda com a perda esperada, corrigindo a distorção ocasionada pelo tratamento dos créditos em atraso, principalmente pelo fato de que, em Basiléia II, o eventual excesso de provisões em relação às perdas esperadas pode ser descontado apenas parcialmente da exigência total de capital. ${ }^{83}$ Seria desejável que a regra para o provisionamento fosse coerente com o modelo de alocação de capital.

Esse pode ser um problema complexo para o regulador, uma vez que os critérios de atraso têm, conforme discutido, uma função moderadora à liberdade concedida às instituições financeiras para modelarem e provisionarem seus riscos. A mera supressão desse parâmetro da norma deixaria o órgão de supervisão sem um elemento estritamente objetivo, que pode ser fundamental para garantir a possibilidade de disciplinar, intervir e liquidar instituições financeiras com base em critério seguro do ponto de vista jurídico.

As abordagens IRB destinam-se a poucas instituições, complexas e sofisticadas, enquanto a Resolução CMN 2.682/99 abrange todo o SFN, desde a menor e mais simples cooperativa de crédito até os bancos de grande porte e maior capacidade de gestão de riscos. Assim, uma solução sugerida seria no sentido de permitir um tratamento diferenciado para os bancos que adotassem as abordagens baseadas em modelos internos, atrelando o cálculo de suas provisões para fins contábeis de modo mais preciso às perdas esperadas. Tal solução, no

\footnotetext{
${ }^{83}$ Apenas no capital de Nível II e limitado ao montante de 0,6\% (seis décimos) do APR.
} 
entanto, teria o efeito perverso de acirrar a desigualdade competitiva entre os bancos que não puderem adotar as abordagens baseadas em modelos internos.

Sobre a evolução necessária da Resolução CMN 2.682/99, alguns entrevistados fizeram considerações críticas sobre os percentuais fixos de provisão. Segundo afirmaram, o provisionamento nesses percentuais fixos bloquearia a constituição da provisão em função das perdas esperadas, nos casos em que estas fossem distintas dos percentuais previstos na norma. Para o autor, tais críticas no entanto não se aplicam, dado que a norma não estabelece percentuais fixos, mas sim faixas de provisão, cabendo às instituições financeiras constituir o montante que julgarem necessário à cobertura das perdas que esperam em função dos riscos. ${ }^{84}$

Outras observações foram feitas em relação ao efeito arrasto ou contaminação, que distanciaria a provisão normativa das perdas esperadas. Esse efeito, previsto no Artigo $3^{\circ}$ da norma, determina que o risco dos créditos de um mesmo tomador deve ser definido considerando sua operação de maior risco, o que, segundo os respondentes, desconsideraria as diferentes estruturas de operação e garantias, portanto a LGD específica de cada operação. No entender do autor, essa crítica decorre de uma interpretação excessivamente restritiva da norma, pois o próprio artigo $3^{\circ}$ prevê que, excepcionalmente, o efeito arrasto pode ser desconsiderado justamente em função das características da operação e suas garantias.

Finalmente, um dos entrevistados relatou experiência vivenciada quando da visita de um analista de rating estrangeiro que não conhecia até então a regulação brasileira para risco de crédito. Segundo o entrevistado, tal analista teria se surpreendido com o nível de delegação aos bancos para mensurar e provisionar o risco de crédito, afirmando que tal conceito seria comparável ao ambiente previsto por Basiléia II. Teria ficado mais surpreso ainda ao saber que essa norma seria válida para todas as instituições do SFN e não apenas àquelas que se submetessem a autorizações específicas do BACEN para tal.

Esse relato ilustra o fato de que as similaridades entre a Resolução CMN 2.682/99 e Basiléia II, apresentadas ao longo deste trabalho, sobressaem mais ao observador externo, que toma contato com a regulação brasileira depois de conhecer os conceitos de Basiléia II, do que

\footnotetext{
${ }^{84} \mathrm{O}$ tratamento normativo da provisão por faixas e não por percentuais fixos foi tratado no capítulo anterior, item 5.3.3.1.
} 
àqueles que incorporaram as exigências da norma brasileira às suas rotinas e procedimentos e depois tomaram contato com Basiléia II.

Para concluir, vale retomar afirmação contida no item 5.3.4 deste trabalho, no sentido de ser a Resolução CMN 2.682/99 mais ousada que Basiléia II no que tange à auto-regulação, pois introduz e aplica a idéia de modelo interno sem validação prévia para todas as instituições do SFN, ainda que, tanto uma quanto outra estruturas regulatórias possuam elementos com a função de moderar a liberdade concedida às instituições financeiras.

\subsection{Modelagem de risco e validação de modelos}

As respostas obtidas foram em sua quase totalidade no sentido de que a Resolução CMN 2.682/99 implantou o conceito de avaliação e mensuração do risco de crédito de modo generalizado no SFN. Para cumprir a exigência normativa, instituições que não possuíam modelos de classificação passaram a ter que discutir o assunto interna e externamente e a definir e formalizar seus próprios critérios para poderem implementar seus modelos. Esse processo propiciou uma melhora qualitativa na condições para concessão, monitoramento e controle de crédito, bem como para a disseminação posterior de modelos estatísticos voltados para decisão de crédito, como credit e behaviour scorings. ${ }^{85}$

A maioria dos pesquisados afirmou que as instituições em que atuam trabalhava internamente com modelos como esses ou com ratings, sendo que apenas representantes de duas instituições reconheceram que não se valiam de tais ferramentas antes da edição da norma. Há um reconhecimento de que a exigência regulatória pôs o tema da mensuração do risco de crédito em evidência, possibilitando a absorção e implantação em ritmo acelerado das técnicas de modelagem que se encontravam disseminadas no exterior à época, criando as condições necessárias à evolução para o ambiente de Basiléia II.

Sobre a importância da norma no aprendizado para a validação de modelos, foram poucas as respostas que confirmassem esse ponto. $\mathrm{O}$ que foi citado, por dois entrevistados, refere-se ao

\footnotetext{
${ }^{85}$ Modelos de tomada de decisão baseados em pontuações (escores) atribuídas aos tomadores de crédito segundo suas características.
} 
uso de algum tipo de back-test $^{86}$ e de matrizes de migração ${ }^{87}$, ou seja, validações de natureza quantitativa. Não foi mencionado qualquer tipo de validação qualitativa, associada à revisão dos processos de modelagem de modo independente, as exigências de documentação, aos use tests e outros aspectos exigidos por Basiléia II. E, de fato, seria pouco provável obter essa confirmação junto aos entrevistados, pois o processo de avaliação em moldes qualitativos parcialmente assemelhados a Basiléia II vem sendo realizado pelo BACEN, em seu processo de supervisão, e não pelas instituições financeiras.

O BACEN, em seus trabalhos de supervisão direta e indireta sobre as carteiras de crédito das instituições, realiza procedimentos que guardam semelhanças, ainda que limitadas, com o que Basiléia II denomina validação. Do ponto de vista quantitativo, acompanhamento constante, direto e indireto, das matrizes de migração e das perdas realizadas frente às provisões constituídas são os principais fatores de monitoramento. Do ponto de vista qualitativo, a revisão, em alguns trabalhos específicos, dos modelos de rating e de seus critérios e do efetivo uso desses modelos na tomada de decisão, além da avaliação da documentação dos modelos e de testes simples para verificação de sua consistência.

Tal conjunto de procedimentos tende a formar o ponto de partida para a definição do processo de autorização do uso de modelos internos, que consiste num dos desafios ao órgão regulador, conforme discutido a seguir.

\subsection{Principais questões relacionadas ao órgão regulador}

Uma preocupação manifesta por pelos menos três dos entrevistados refere-se ao processo de autorização para uso de modelos internos, mais especificamente sobre como assegurar homogeneidade de critérios de avaliação, dado que tais processos podem vir a ser realizados por pessoas e equipes distintas, ou seja como reduzir a influência de fatores subjetivos nos critérios de avaliação.

\footnotetext{
${ }^{86}$ Comparação entre a provisão atribuída e a perda realizada.

${ }^{87}$ Quadros comparativos que permitem verificar qual porcentagem dos créditos se manteve na mesma classificação de risco após um período de tempo e qual a porcentagem que migrou para outros níveis, calculados individualmente.
} 
Os entrevistados também consideram desafiadoras as questões relativas à formação e retenção de pessoal qualificado para discutir e avaliar criticamente os modelos de risco, dadas a dificuldades de natureza orçamentária e de contratação de funcionários inerentes à esfera pública, dificuldade inclusive compartilhada pelos bancos de capital estatal.

Quanto à atuação do órgão regulador, os entrevistados em sua maioria registraram que tem havido bom nível de diálogo entre os bancos e o BACEN, mas avaliam que esse diálogo precisa ser mais aprofundado e constante, dado tratar-se de um processo de aprendizado compartilhado. Houve ainda algumas demandas para que o BACEN, quando da rejeição das propostas do setor nas audiências públicas, procure tornar mais claras as causas da rejeição, não como questionamento da autoridade do regulador, mas para fortalecer precisamente o necessário diálogo e aprendizado comum.

Outro aspecto refere-se ao cronograma estabelecido, especialmente a definição acerca das exigências para as bases de dados, previstas para serem divulgadas até o final de 2008. Essa é uma questão que tem gerado preocupações pelo fato de que quaisquer correções podem demandar um prazo longo de adaptação, interferindo e causando até mesmo retrocessos no processo de estruturação das bases de dados e na modelagem de riscos.

Um ponto mencionado refere-se à necessidade de definição sobre qual será o prazo de inadimplência definido para os modelos internos, se 90 dias, conforme consta de Basiléia II, ou 60 dias, conforme a prática mais comum de mercado, ou se ambas serão aceitas. Essa é uma questão preocupante, pois essa definição pode levar a que muitos modelos tenham de ser reformulados, prejudicando o seu teste de uso ao longo do tempo. ${ }^{88}$

\subsection{Andamento do processo de adaptação}

A grande maioria dos entrevistados afirmou que suas instituições têm perspectivas de implementar as abordagens baseadas em modelos internos nos anos de 2008 e 2009, sendo

\footnotetext{
${ }^{88}$ Modelos de escoragem tem entre suas premissas iniciais a definição do período de inadimplência a ser considerado, sendo os dados modelados a partir dessas premissas. Uma exigência de um prazo específico distinto pode simplesmente determinar a inaplicabilidade de um determinado modelo.
} 
que, em dois casos, a instituição as tem implementadas para fins de prestação de informações à matriz no exterior. Essa avaliação sobre os prazos deve ser relativizada no sentido de que:

- duas instituições não declararam horizonte de tempo, com uma delas assegurando que estaria pronta nas janelas de oportunidade de autorização abertas pelo BACEN;

- uma instituição declarou a perspectiva de adoção da abordagem avançada no início de 2009, mas, comparativamente às demais, encontra-se em estágio bem anterior nesse processo;

- algumas dessas instituições consideraram esse prazo (2008/2009) para a disponibilidade dos modelos para uso da alta administração, mas sem cumprir os prazos exigidos por Basiléia II para o horizonte temporal de dados (5 a 7 anos), nem os processos internos de validação. Tais aspectos foram estimados por uma única instituição, acrescentando dois anos ao prazo para apenas possuir e utilizar os modelos nos moldes de Basiléia II.

Quanto às etapas a serem cumpridas, a quase totalidade dos entrevistados apontou que suas instituições tinham pendente ainda a conclusão da base de dados para a LGD, bem como sua modelagem, além dos processos internos de documentação e validação.

\subsection{Relação custo-benefício}

Para a totalidade dos entrevistados, os benefícios da adaptação a Basiléia II compensam os elevados custos financeiros, decorrentes principalmente dos investimentos em tecnologia de informação, de alocação de pessoal e de treinamento.

O principal benefício apontado está na melhoria de processos internos e de gestão, de modo que o principal ganho estaria na qualidade de governança institucional e não numa eventual economia de capital regulatório. Muitos dos projetos necessários à implementação de Basiléia II tem custos elevados, mas teriam de ser efetuados de qualquer modo, em algum momento. A necessidade de adaptação à regulação tem operado como um catalisador para realização desses projetos. 
Do ponto de vista de riscos, Basiléia II tende a disseminar, internamente e no SFN, uma precificação ajustada ao risco no nível do cliente e da operação, sendo um diferencial competitivo significativo. Pode também contribuir para uma redução dos spreads bancários, pela visão mais precisa do risco efetivamente incorrido e sua correta cobrança, possibilitando também uma gestão ativa da carteira de crédito.

Acima de qualquer avaliação de custo-benefício, alguns entrevistados declararam que para bancos com atuação internacional, independente da origem de seu capital, público ou privado, nacional ou estrangeiro, a adoção das abordagens baseadas em modelos internos é mandatória. Para tais bancos, não ter a autorização do regulador para utilizar essas abordagens representa uma chancela de que os mesmos não adotam as melhores práticas do segmento, impactando diretamente a avaliação recebida por seus pares e por investidores institucionais, além de agências de rating, o que traz efeitos negativos diretos em seus custos de captação e, portanto, na sua própria capacidade competitiva. 


\section{CONCLUSÕES}

Este trabalho tem o objetivo de analisar o processo de evolução da regulamentação para risco de crédito no Brasil, de modo a propiciar um quadro comparativo entre o ambiente regulatório atual e aquele delineado por Basiléia II, proporcionando uma reflexão sobre os desafios na implantação dessa versão do acordo de capitais no país.

Reconstituindo o ambiente operacional à época das Resoluções CMN 1.559/88 e 1.748/90, bem como revisando aspectos de regulação bancária e Basiléia I, procurou-se a construção do arcabouço teórico necessário à discussão da implantação de Basiléia II no Brasil. Ao atrelar essa discussão à análise minuciosa da Resolução CMN 2.682/99, buscou-se explorar a experiência adquirida nos últimos oito anos com uma norma que implantou vários dos conceitos introduzidos internacionalmente por Basiléia II.

Mediante a realização de pesquisa junto a uma amostra de executivos de instituições financeiras envolvidos com o tema foram obtidos elementos para suportar as constatações realizadas a partir da análise da regulação para crédito, bem como explorar aspectos relativos ao processo e às condições de implementação de Basiléia II no país.

A pesquisa confirmou a hipótese de que parte relevante das dificuldades para adaptação a Basiléia II encontra-se em questões de natureza operacional. No caso, tais dificuldades se manifestam menos na construção dos modelos de PD, LGD e EAD do que na coleta e estruturação dos dados necessários para sua estimação dentro dos parâmetros definidos pelo Comitê da Basiléia.

Outro aspecto da pesquisa refere-se ao fato da maioria dos entrevistados ter se mostrado ciente de que os modelos utilizados para fins de cômputo do capital próprio devem ser aqueles efetivamente utilizados pela instituição no gerenciamento do dia-a-dia dos seus negócios, o use test, sem o que perde-se a base conceitual de Basiléia II de aproximar o capital regulamentar do capital econômico e, portanto, sua eficácia como marco regulatório. Os pesquisados, ao destacarem o desafio da mudança cultural interna das instituições financeiras, realçaram que Basiléia II não tem caráter meramente regulatório, mas relacionase principalmente com a adoção das melhores práticas de gestão de riscos e com formas mais 
precisas de medir, incentivar e aperfeiçoar o desempenho organizacional. No caso do risco de crédito, relaciona-se com a adequada mensuração dos riscos incorridos, possibilitando um nível mais preciso de precificação ajustada ao risco, levando a melhores condições de competitividade e gestão de riscos e carteiras.

$\mathrm{Na}$ percepção dos entrevistados, as pré-condições para adoção no Brasil das abordagens baseadas em modelos internos de Basiléia II foram criadas pela Resolução CMN 2.682/99. Ao determinar que os bancos e demais instituições financeiras passassem a classificar suas operações de crédito em função do risco efetivamente incorrido e calcular suas provisões em função das classificações apuradas, a norma introduziu no âmbito regulatório a questão da avaliação prospectiva do risco de crédito, contribuindo para a disseminação do uso de modelos para a mensuração de riscos de crédito no SFN.

Há outras questões complexas de Basiléia II que guardam semelhanças com a Resolução CMN 2.682/99 e tem sua compreensão facilitada a partir da análise do caso da norma brasileira. As abordagens de Basiléia II fundamentadas em ratings internos consideram três elementos chave, PD, LGD e EAD, que compõem as perdas esperadas e são estimados pelos próprios bancos para cada exposição ao risco de crédito. Tais dados servem como base para o cálculo do encargo de capital a ser exigido, desde que todo o processo de mensuração e gestão do risco de crédito tenha sido avaliado previamente pela supervisão bancária. Os elementos fundamentais para o cálculo do capital exigido baseiam-se em medidas e estimativas dos próprios bancos, de modo semelhante ao que ocorre na aplicação da Resolução CMN $2.682 / 99$.

A norma brasileira destina-se ao cálculo da constituição das provisões em função das perdas esperadas em suas operações de crédito. Para tal, baseia-se em elementos medidos e estimados pelos próprios bancos a partir de seus modelos internos. Além do fato de as provisões representarem uma parte do capital exigido dos bancos, mas não o capital total, a principal diferença com relação a Basiléia II é que, no caso da Resolução CMN 2.682/99, não há necessidade de aceitação prévia por parte da supervisão bancária para utilização desses modelos e critérios. Durante a ação regular de supervisão, com amparo na própria norma, o supervisor bancário pode ou não aceitar os modelos e processos utilizados pelos bancos, o que, de certa forma, remete aos processos de autorização previstos por Basiléia II. 
Por ter a Resolução CMN 2.682/99 e seu processo de aplicação larga margem para interpretação subjetiva, a fundamentação para ações de natureza legal torna-se mais complexa e incerta, podendo por isso vir a enfraquecer o poder efetivo de aplicação da norma pelo Banco Central. A estrutura regulatória de Basiléia II guarda similaridades com esses mesmos aspectos e tais dificuldades podem se repetir na sua implantação no Brasil.

Pelo fato de os modelos normativos tanto de Basiléia II quanto da Resolução CMN 2.682/99 terem seus processos de aplicação caracterizados por margens para interpretação subjetiva, a fundamentação para ações de natureza legal pode tornar-se mais complexa e incerta, reduzindo o enforcement do Banco Central nas situações que envolvem a necessidade de aplicar disciplina a alguma instituição financeira, sendo mais crítica especialmente nos casos extremos de intervenção e liquidação de bancos.

Desse aspecto surge uma demanda por pesquisas adicionais que fogem ao escopo desta dissertação, a fim de compreender e avaliar os impactos da adoção, em países de tradição de direito codificado, de modelos de regulação desenvolvidos para ambientes de tradição legal consuetudinária, especialmente no que se refere à regulação dos sistemas financeiros.

Outro aspecto de interesse para pesquisas adicionais relaciona-se aos requisitos de divulgação do Pilar 3, que tendem a aumentar o volume de informações à disposição dos analistas e investidores. Uma contribuição adicional seria testar se a redução nas assimetrias de informação justifica o ponto de vista dos autores que atribuem ao Pilar 3 maior eficiência na redução da instabilidade financeira que aos Pilares 1 e 2, ampliando o foco dos pesquisadores sobre o tema da regulação bancária e financeira.

Finalmente, este trabalho deve ser interpretado como uma contribuição para a discussão e compreensão do quadro normativo brasileiro para risco de crédito, ao propiciar uma reflexão sobre as condições para a implantação de Basiléia II no Brasil a partir das realidades das instituições financeiras e do arcabouço institucional do país, especialmente quanto às particularidades dos ambientes operacional e regulatório para crédito. 


\section{REFERÊNCIAS}

ALBUQUERQUE, Ariel Santos de. Um estudo quantitativo sobre os reflexos da Resolução 2.682 do BACEN na constituição de provisões para créditos de liquidação duvidosa nas instituições financeiras. Dissertação de mestrado. Faculdade de Economia, Administração e Contabilidade da Universidade de São Paulo. São Paulo, 2005.

ANDREWS, Charles A.; HAUBENSTOCK, Michael J. Implementação do Novo Acordo da Basiléia. Revista Tecnologia de Crédito, Ed. 37. São Paulo: Serasa, julho/2003.

ANDREZO, Andrea Fernandes; LIMA, Iran Siqueira - Mercado financeiro: aspectos históricos e conceituais. $2^{a}$ Edição Revista e Ampliada. São Paulo: Pioneira Thomson Learning, 2002.

ANTONOV, Ivo. Delineando o panorama do mercado: sistemas quantitativos e subjetivos de rating de risco de crédito. Revista Tecnologia de Crédito. Ed. 29. São Paulo: Serasa, março/2002.

BANCO CENTRAL DO BRASIL - BCB. Circulares 2.916/99, 3.031/01 e 3.360/07, Comunicados 12.746, de 09.12.2004, e 16.137, de 27.09.2007, e Nota à Imprensa, de 14.07.2007.

BANCO CENTRAL DO BRASIL - BCB. Juros e Spread Bancário no Brasil. Brasília, DF: Out/1999. Disponível em <http://www.bcb.gov.br/ftp/juros-spread1.pdf>. Acesso em $31 / 05 / 2005$.

BANCO CENTRAL DO BRASIL - BCB. Relatório de Economia Bancária e Crédito. Brasília, DF: 2005. Disponível em <http://www.bcb.gov.br/pec/spread/port/ rel_econ_ban_cred.pdf>. Acesso em 21/08/2006.

BANCO CENTRAL DO BRASIL - BCB. Supervisão Bancária no contexto de Basiléia II. Apostila. São Paulo: Banco Central do Brasil - Desup, 2006.

BANCO CENTRAL DO BRASIL - BCB. Risco de Mercado - Introdução e aspectos regulatórios. Apostila. São Paulo: Banco Central do Brasil - Desup, 2007.

BANCO INTERAMERICANO DE DESENVOLVIMENTO - BID. Libertar o Crédito: Como aprofundar e estabilizar o financiamento bancário. Rio de Janeiro: Elsevier, 2005. 
BANK FOR INTERNATIONAL SETTLEMENTS - BIS. The banking industry in emerging market economies: competition, consolidation and systemic stability. BIS Papers n.4. Basiléia: BIS, august/2001.

BANK FOR INTERNATIONAL SETTLEMENTS - BIS. Disponível em $<$ http://www.bis.org/bcbs/index.htm>; $\quad<$ http://www.bis.org/bcbs/history.htm> e $<$ http://www.bis.org/about/index.htm>. Acesso em 17.07.2007.

BASEL COMITTEE ON BANKING SUPERVISION - BCBS. International convergence of capital measurement and capital standards. Basiléia: Basel Committee Publications, 1988.

BASEL COMITTEE ON BANKING SUPERVISION - BCBS. Principles for the management of credit risk. Basiléia: Basel Committee Publications, 2000.

BASEL COMITTEE ON BANKING SUPERVISION - BCBS. Implementation of Basel II: practical considerations. Basiléia: Basel Committee Publications, 2004a.

BASEL COMITTEE ON BANKING SUPERVISION - BCBS. International convergence of capital measurement and capital standards. A revised framework. Basiléia: Basel Committee Publications. Tradução Febraban, 2004b.

BASEL COMITTEE ON BANKING SUPERVISION - BCBS. An explanatory note on the Basel II IRB risk weight functions. Basiléia: Basel Committee Publications, 2005.

CALOMIRIS, Charles W.; POWELL, Andrew. Can Emerging Market Bank Regulators Establish Credible Discipline? The Case of Argentina, 1992-1999. May, 2000. Artigo disponível em SSRN - Social Science Research Network <http://www.ssrn.org>.

CAOUETTE, John B.; ALTMAN, Edward I. e NARAYANAN, Paul. Gestão do risco de crédito: o próximo desafio financeiro. Rio de Janeiro: Qualitymark, 1999.

CARVALHO, Fernando José Cardim. Inovação financeira e regulação prudencial: da regulação de liquidez aos acordos de Basiléia. In SOBREIRA, Rogério. (org). Regulação Financeira e Bancária. São Paulo: Editora Atlas, 2005. 
CONSELHO MONETÁRIO NACIONAL - CMN. Resoluções 1559/88, 1.748/90, 2.099/94, 2.543/98, 2.554/98, 2.682/99, 2.697/00, 2.837/01, 2.844/02, 3.444/07 e 3.490/07.

CORAZZA, Gentil. Os dilemas da supervisão bancária. In SOBREIRA, Rogério. (org). Regulação Financeira e Bancária. São Paulo: Editora Atlas, 2005.

FREIRE FILHO, Antonio Augusto de Sá - Provisão para créditos de liquidação duvidosa nas instituições bancárias: comparação das práticas contábeis estadunidenses e brasileiras. Dissertação de mestrado. Brasília: UnB, 2002.

FREITAS, Maria.Cristina Penido de. A evolução dos bancos centrais e seus desafios no contexto da globalização financeira. São Paulo: Revista Estudos Econômicos v.30, n.3, p.397-417, julho-setembro 2000.

FREITAS, Maria Cristina Penido de; PRATES, Daniela Magalhães. As novas regras do comitê da Basiléia e as condições de financiamento dos países periféricos. In SOBREIRA, Rogério. (org). Regulação Financeira e Bancária. São Paulo: Editora Atlas, 2005.

FURTAdO, Ana Lilian de Menezes. Acordo da Basiléia: Um estudo sobre as suas influências e implementação no Sistema Financeiro Brasileiro. Monografia. Florianópolis: UFSC, 2005.

GARCIA, Valéria Salomão. Gestão de Risco de Crédito e Regulamentação: uma reflexão sobre o caso brasileiro. Dissertação de mestrado. São Paulo: EAESP/FGV, 2002.

GORGA, Érica; SZTAJN, Rachel. Tradições do direito. In: SZTAJN, Rachel; ZYLBERSZTAJN, Décio. (Org.). Direito e Economia: Análise Econômica do Direito e das Organizações. Rio de Janeiro: Elsevier, 2005.

GOULART, Andre Moura Cintra. Evidenciação contábil do risco de mercado por instituições financeiras no Brasil. Dissertação de mestrado. Faculdade de Economia, Administração e Contabilidade da Universidade de São Paulo. São Paulo: FEA/USP, 2003.

HOFFMAN, S. Implementing Basel II in the United Status: overview of timing and challenges for implementation. $2^{\circ}$ seminário técnico do Mercosul sobre Basiléia II, 2004. 
KANE, Edward. Competitive financial reregulation: an international perspective. In: PORTES, R. e SWOBODA, A.K. (Ed.) Threats to international financial stability. Cambridge: Cambridge University Press, 1987.

KOCH, Timothy W.; MACDONALD, S. Scott. Bank management. $4^{\text {th }}$ ed.The Dryden Press Hardcourt College Publishers, 2000 apud GARCIA, Valéria Salomão. Gestão de Risco de Crédito e Regulamentação: uma reflexão sobre o caso brasileiro. Dissertação de mestrado. São Paulo: EAESP/FGV, 2002.

LAKATOS, Eva Maria; MARCONI, Marina de Andrade. Metodologia do trabalho científico. $4^{\text {a }}$ Edição. São Paulo: Editora Atlas, 1992.

LIMA, Gilberto Tadeu. Evolução recente da regulação bancária no Brasil. In SOBREIRA, Rogério. (org). Regulação financeira e bancária. São Paulo: Editora Atlas, 2005.

LOFRANO, Carlos Eduardo Sampaio. Gerenciamento da carteira de créditos de bancos: uma visão regulatória. Revista Tecnologia de Crédito, Ed. 23. São Paulo: Serasa, março/2001.

LUNDBERG, Eduardo. Rede de proteção e saneamento do sistema bancário. In SADDI, Jairo (org.). Intervenção e liquidação extrajudicial no Sistema Financeiro Nacional: 25 anos da Lei 6.024/74. São Paulo: Textonovo, 1999.

MAJNONI, Giovanni; MILLER, Margaret; POWELL, Andrew. Bank capital and loan loss reserves under Basel II: Implication for Latin America and Caribbean Countries. Artigo disponível em SSRN - Social Science Research Network <www.ssrn.org>, 2004.

MARION, José Carlos. Contabilidade Empresarial. $8^{a}$ Edição. São Paulo: Editora Atlas, 1998.

MARTINS, Gilberto de Andrade. Manual para elaboração de monografias e dissertações. $2^{a}$ edição. São Paulo: Editora Atlas, 2000.

MARTINS, Gilberto de Andrade. Manual para formatação e edição de dissertações e teses. Apostila. PPGA, FEA/USP-SP. São Paulo, 2004.

MENDOZA, Juan; STEPHANOU, Constantinos. Credit Risk Measurement Under Basel II: an overview and implementation issues for developing countries. Working Paper Series. Washington DC: The World Bank, 2005 
MORAL, Gregorio. Validación de Enfoques IRB para el cálculo del capital mínimo por riesgo de crédito. Revista Estabilidad Financiera, $n^{\circ}$ 7, novembro de 2004. Madrid: Banco de España, 2004.

MORAL, Gregorio. Validación Supervisora de Enfoques IRB. $2^{\circ}$ seminário técnico do Mercosul sobre Basiléia II, 2004.

MORAL, Gregorio. Validación Supervisora: lecciones de la experiência española y ejemplos. $2^{\circ}$ seminário técnico do Mercosul sobre Basiléia II, 2004.

NIYAMA, Jorge Katsumi; GOMES, Amaro L. Oliveira. Contabilidade de Instituições Financeiras. $3^{\mathrm{a}}$ ed. São Paulo: Atlas, 2005.

PANDELÓ JR, Domingos R. Avaliação do risco de instituições financeiras. Revista Tecnologia de Crédito, Ed. 18. São Paulo: Serasa, maio/2000.

PARENTE, Guilherme González Cronemberger. As novas normas de classificação de crédito e o disclosure das provisões: uma abordagem introdutória. $9^{a}$ semana de contabilidade do Banco Central do Brasil: nov/2000.

PINHEIRO, Armando Castelar. O componente Judicial dos Spreads Bancários. In BANCO CENTRAL DO BRASIL. Economia Bancária e Crédito: Avaliação de $\mathbf{4}$ anos do projeto Juros e Spread Bancário. Brasília, BCB: 2003. Disponível em $<$ http://www.bcb.gov.br/ftp/rel_economia_bancaria_credito.pdf>. Acesso em 31/05/2005.

PINHEIRO, Armando Castelar. Magistrados, Judiciário e Economia no Brasil. In: ZYLBERSZTAJN, Décio; SZTAJN, Rachel (Org.). Direito e Economia: Análise Econômica do Direito e das Organizações. Rio de Janeiro: Elsevier, 2005.

POWELL, Andrew. A capital acord for emerging economies? Working paper series. Washington DC: The World Bank, 2002

POWELL, Andrew. Implicaciones de Basilea II para America Latina. Revista Estabilidad Financiera, nº 6. Madrid: Banco de España, 2004. 
POWELL, Andrew. Towards Basel III - Emerging. Artigo disponível em SSRN - Social Science Research Network <www.ssrn.org>, 2006.

PRADO, Renata Grunberg Almeida; BASTOS, Norton Torres de; DUARTE Jr., Antonio Marcos. Gerenciamento de riscos de crédito em bancos de varejo no Brasil. 2001. Disponível em <http://www.risktech.com.br/PDFs/unicredit_varejo.pdf>. Acesso em 10.07.2007

RODRIGUES, Raimundo Nonato. O acordo da Basiléia: um estudo da adequação de capital nas instituições financeiras brasileiras. Dissertação de mestrado. São Paulo: FEA/USP, 1998.

ROCHA, Fernando Alberto Sampaio. Evolução da Concentração Bancária no Brasil (1994-2000). Notas Técnicas do Banco Central do Brasil. Brasília: BCB, 2001.

ROCHET, Jean Charles. Rebalancing the three pillars of Basel II. New York: Federal Reserve Bank of New York Economic Policy Review, September, 2004.

SADEK, M.T. A crise do judiciário vista pelos juízes: resultados da pesquisa quantitativa. In: Uma introdução ao estudo da Justiça. Editora Sumaré, 1995 apud PINHEIRO, Armando Castelar. Magistrados, Judiciário e Economia no Brasil. In: ZYLBERSZTAJN, Décio; SZTAJN, Rachel (Org.). Direito e Economia: Análise Econômica do Direito e das Organizações. Rio de Janeiro: Elsevier, 2005.

SAUNDERS, Anthony. Administração de instituições financeiras. $2^{\mathrm{a}}$ Ed. São Paulo: Atlas, 2000.

SAUNDERS, Anthony. Medindo o risco de crédito: Novas abordagens para Value At Risk e outros paradigmas. Rio de Janeiro: Qualitymark, 2000.

SANTOS, Cláudia Barreto dos. Gestão de risco de crédito em instituições financeiras. Dissertação de mestrado.São Paulo: FEA/USP, 2000.

SANTOS, José Odálio dos. Análise de Crédito: empresas e pessoas físicas. São Paulo: Atlas, 2000.

SCHECTMAN, Ricardo. et al. Credit Risk measurement and the regulation of bank capital and provision requirements in Brasil: A corporate analysis. Brasília: Banco Central do Brasil - mimeo, 2003. 
SCHECTMAN, Ricardo. Simulação dos efeitos de Basiléia II (IRB) para requerimentos de risco de crédito utilizando dados da Central de Risco. $2{ }^{\text {nd }}$ Credit and Banking Economy Report. Brasília: Banco Central do Brasil, 2003.

SILVA, Denis Blum Ratis e. O impacto de requerimentos de capital na oferta de crédito bancário no Brasil . Dissertação de mestrado. São Paulo: FEA/USP, 2005.

SZTAJN, Rachel. Law and Economics. In: SZTAJN, Rachel; ZYLBERSZTAJN, Décio. (Org.). Direito e Economia: Análise Econômica do Direito e das Organizações. Rio de Janeiro: Elsevier, 2005.

TONETO JR, R. e GREMAUD, A. O Acordo de Basiléia e a instabilidade financeira. Revista Economia e Empresas, Vol.1, n 2, Outubro-Dezembro/1994. apud FURTADO, Ana Lilian de Menezes. Acordo da Basiléia: Um estudo sobre as suas influências e implementação no Sistema Financeiro Brasileiro. Monografia. Florianópolis: UFSC, 2005.

TRUCHARTE, Carlos. A review of Credit Registers and their use for Basel I'. FSI Award 2004 wining paper. Basiléia: Financial Stability Institute, 2004.

TRUCHARTE, Carlos. Provisiones, Centrales de riesgos y benchmarking. $2^{\circ}$ seminário técnico do Mercosul sobre Basiléia II, 2004.

VALOR ECONÔMICO. Bautzer, Tatiana. Estados retêm pagamento de empréstimo consignado. Edição de 22.10.2007.

VIANA, L.W. et al. Corpo e alma da magistratura brasileira. Editora Revan, 1997. apud PINHEIRO, Armando Castelar. Magistrados, Judiciário e Economia no Brasil. In: ZYLBERSZTAJN, Décio; SZTAJN, Rachel (Org.). Direito e Economia: Análise Econômica do Direito e das Organizações. Rio de Janeiro: Elsevier, 2005. 
ANEXOS

ANEXO A - RESOLUÇÃO CMN 2.682/99

ANEXO B - RESOLUÇÃO CMN 1.748/90

ANEXO C - CARTA DE CONFORTO E SIGILO 


\section{ANEXO A - RESOLUÇÃO CMN 2.682/99}

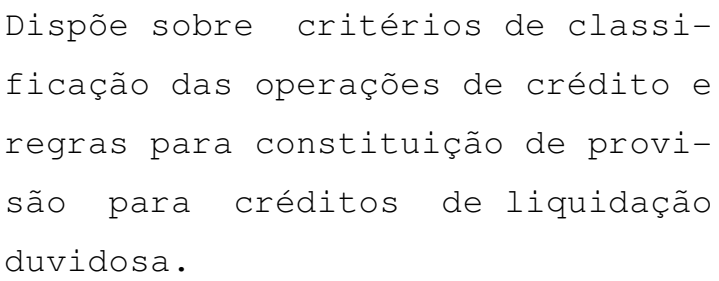

O BANCO CENTRAL DO BRASIL, na forma do art. $9^{\circ}$ da Lei $n^{\circ}$ 4.595, de 31 de dezembro de 1964, torna público que o CONSELHO MONETÁRIO NACIONAL, em sessão realizada em 21 de dezembro de 1999, com base no art. $4^{\circ}$, incisos XI e XII, da citada Lei,

R E S O L V E U:

Art. $1^{\circ}$ Determinar que as instituições financeiras e demais instituições autorizadas a funcionar pelo Banco Central do Brasil devem classificar as operações de crédito, em ordem crescente de risco, nos seguintes níveis:

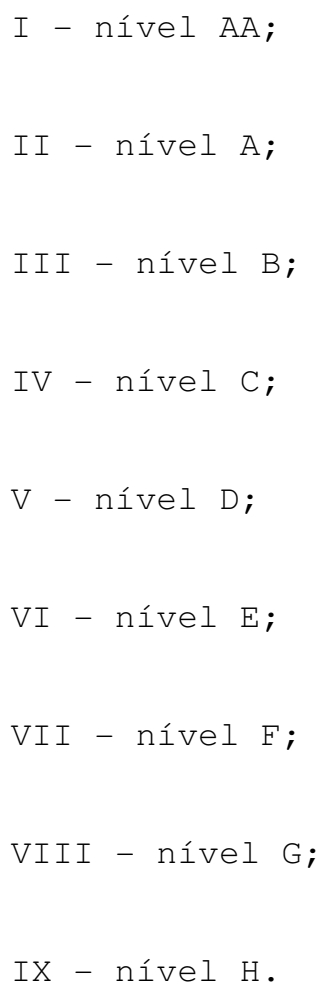


respondente é de responsabilidade da instituição detentora do crédito e deve ser efetuada com base em critérios consistentes e verificáveis, amparada por informações internas e externas, contemplando, pelo menos, os seguintes aspectos:

I - em relação ao devedor e seus garantidores:

a) situação econômico-financeira;

b) grau de endividamento;

c) capacidade de geração de resultados;

d) fluxo de caixa;

e) administração e qualidade de controles;

f) pontualidade e atrasos nos pagamentos;

g) contingências;

h) setor de atividade econômica;

i) limite de crédito;

II - em relação à operação:

a) natureza e finalidade da transação;

b) características das garantias, particularmente quanto à suficiência e liquidez;

c) valor.

Parágrafo único. A classificação das operações de crédito de titularidade de pessoas físicas deve levar em conta, também, as situações de renda e de patrimônio bem como outras informações cadastrais do devedor.

Art. $3^{\circ}$ A classificação das operações de crédito de um mesmo cliente ou grupo econômico deve ser definida considerando aquela que 
apresentar maior risco, admitindo-se excepcionalmente classificação diversa para determinada operação, observado o disposto no art. $2^{\circ}$, inciso II.

Art. $4^{\circ}$ A classificação da operação nos níveis de risco de que trata 0 art. $1^{\circ}$ deve ser revista, no mínimo:

I - mensalmente, por ocasião dos balancetes e balanços, em função de atraso verificado no pagamento de parcela de principal ou de encargos, devendo ser observado o que segue:

a) atraso entre 15 e 30 dias: risco nível B, no mínimo;

b) atraso entre 31 e 60 dias: risco nível C, no mínimo;

c) atraso entre 61 e 90 dias: risco nível D, no mínimo;

d) atraso entre 91 e 120 dias: risco nível E, no mínimo;

e) atraso entre 121 e 150 dias: risco nível F, no mínimo;

f) atraso entre 151 e 180 dias: risco nível G, no mínimo;

g) atraso superior a 180 dias: risco nível H;

II - com base nos critérios estabelecidos nos arts. $2^{\circ}$ e $3^{\circ}$ :

a) a cada seis meses, para operações de um mesmo cliente ou grupo econômico cujo montante seja superior a 5\% (cinco por cento) do patrimônio líquido ajustado;

b) uma vez a cada doze meses, em todas as situações, exceto na hipótese prevista no art. $5^{\circ}$.

Parágrafo $1^{\circ}$ As operações de adiantamento sobre contratos de câmbio, as de financiamento à importação e aquelas com prazos inferiores a um mês, que apresentem atrasos superiores a trinta dias, bem como o adiantamento a depositante a partir de trinta dias de sua ocorrência, devem ser classificados, no mínimo, como de risco nível G. 
Parágrafo $2^{\circ}$ Para as operações com prazo a decorrer superior a 36 meses admite-se a contagem em dobro dos prazos previstos no inciso I.

Parágrafo $3^{\circ} \mathrm{O}$ não atendimento ao disposto neste artigo implica a reclassificação das operações do devedor para o risco nível $\mathrm{H}$, independentemente de outras medidas de natureza administrativa.

Art. $5^{\circ}$ As operações de crédito contratadas com cliente cuja responsabilidade total seja de valor inferior a R\$50.000,00 (cinqüenta mil reais) podem ter sua classificação revista de forma automática unicamente em função dos atrasos consignados no art. 4\%, inciso I, desta Resolução, observado que deve ser mantida a classificação original quando a revisão corresponder a nível de menor risco.

Parágrafo $1^{\circ}$ O Banco Central do Brasil poderá alterar o valor de que trata este artigo.

Parágrafo $2^{\circ} 0$ disposto neste artigo aplica-se às operações contratadas até 29 de fevereiro de 2000, observados o valor referido no caput e a classificação, no mínimo, como de risco nível A.

Art. $6^{\circ}$ A provisão para fazer face aos créditos de liquidação duvidosa deve ser constituída mensalmente, não podendo ser inferior ao somatório decorrente da aplicação dos percentuais a seguir mencionados, sem prejuízo da responsabilidade dos administradores das instituições pela constituição de provisão em montantes suficientes para fazer face a perdas prováveis na realização dos créditos:

I - 0,5\% (meio por cento) sobre o valor das operações classificadas como de risco nível A;

II - 1\% (um por cento) sobre o valor das operações classificadas como de risco nível B;

III - 3\% (três por cento) sobre o valor das operações classificadas como de risco nível C;

IV - 10\% (dez por cento) sobre o valor das operações classificados como de risco nível D; 
$\mathrm{V}$ - 30\% (trinta por cento) sobre 0 valor das operações classificados como de risco nível E;

VI - 50\% (cinqüenta por cento) sobre o valor das operações classificados como de risco nível F;

VII - 70\% (setenta por cento) sobre o valor das operações classificados como de risco nível G;

VIII - 100\% (cem por cento) sobre o valor das operações classificadas como de risco nível H.

Art. $7^{\circ} \mathrm{A}$ operação classificada como de risco nível H deve ser transferida para conta de compensação, com o correspondente débito em provisão, após decorridos seis meses da sua classificação nesse nível de risco, não sendo admitido o registro em período inferior.

Parágrafo único. A operação classificada na forma do disposto no caput deste artigo deve permanecer registrada em conta de compensação pelo prazo mínimo de cinco anos e enquanto não esgotados todos os procedimentos para cobrança.

Art. 8० A operação objeto de renegociação deve ser mantida, no mínimo, no mesmo nível de risco em que estiver classificada, observado que aquela registrada como prejuízo deve ser classificada como de risco nível H.

Parágrafo $1^{\circ}$ Admite-se a reclassificação para categoria de menor risco quando houver amortização significativa da operação ou quando fatos novos relevantes justificarem a mudança do nível de risco.

Parágrafo $2^{\circ} 0$ ganho eventualmente auferido por ocasião da renegociação deve ser apropriado ao resultado quando do seu efetivo recebimento.

Parágrafo $3^{\circ}$ Considera-se renegociação a composição de dívida, a prorrogação, a novação, a concessão de nova operação para liquidação parcial ou integral de operação anterior ou qualquer outro tipo de acordo que implique na alteração nos prazos de vencimento ou nas condições de pagamento originalmente pactuadas. 
Art. 9० É vedado o reconhecimento no resultado do período de receitas e encargos de qualquer natureza relativos a operações de crédito que apresentem atraso igual ou superior a sessenta dias, no pagamento de parcela de principal ou encargos.

Art. 10. As instituições devem manter adequadamente documentadas sua política e procedimentos para concessão e classificação de operações de crédito, os quais devem ficar à disposição do Banco Central do Brasil e do auditor independente.

Parágrafo único. A documentação de que trata o caput deste artigo deve evidenciar, pelo menos, o tipo e os níveis de risco que se dispõe a administrar, os requerimentos mínimos exigidos para a concessão de empréstimos e o processo de autorização.

Art. 11. Devem ser divulgadas em nota explicativa às demonstrações financeiras informações detalhadas sobre a composição da carteira de operações de crédito, observado, no mínimo:

I - distribuição das operações, segregadas por tipo de cliente e atividade econômica;

II - distribuição por faixa de vencimento;

III - montantes de operações renegociadas, lançados contra prejuízo e de operações recuperadas, no exercício.

Art. 12. O auditor independente deve elaborar relatório circunstanciado de revisão dos critérios adotados pela instituição quanto à classificação nos níveis de risco e de avaliação do provisionamento registrado nas demonstrações financeiras.

Art. 13. O Banco Central do Brasil poderá baixar normas complementares necessárias ao cumprimento do disposto nesta Resolução, bem como determinar:

I - reclassificação de operações com base nos critérios estabelecidos nesta Resolução, nos níveis de risco de que trata o art. $1^{\circ}$;

II - provisionamento adicional, em função da responsabilidade do devedor junto ao Sistema Financeiro Nacional; 
III - providências saneadoras a serem adotadas pelas instituições, com vistas a assegurar a sua liquidez e adequada estrutura patrimonial, inclusive na forma de alocação de capital para operações de classificação considerada inadequada;

IV - alteração dos critérios de classificação de créditos, de contabilização e de constituição de provisão;

V - teor das informações e notas explicativas constantes das demonstrações financeiras;

VI - procedimentos e controles a serem adotados pelas instituições.

Art. 14. O disposto nesta Resolução se aplica também às operações de arrendamento mercantil e a outras operações com características de concessão de crédito.

Art. 15. As disposições desta Resolução não contemplam os aspectos fiscais, sendo de inteira responsabilidade da instituição a observância das normas pertinentes.

Art. 16. Esta Resolução entra em vigor na data da sua publicação, produzindo efeitos a partir de $1^{\circ}$ de março de 2000, quando ficarão revogadas as Resoluções $n^{\circ} \mathrm{s} 1.748$, de 30 de agosto de 1990, e 1.999, de 30 de junho de 1993, os arts. $3^{\circ}$ e 5० da Circular n 1.872, de 27 de dezembro de 1990, a alínea "b" do inciso II do art. 40 da Circular $\mathrm{n}^{\circ}$ 2.782, de 12 de novembro de 1997, e o Comunicado $\mathrm{n}^{\circ}$ 2.559, de 17 de outubro de 1991 .

Brasília, 21 de dezembro de 1999

Arminio Fraga Neto

Presidente 


\section{ANEXO B - RESOLUÇÃO CMN 1.748/90}

ALTERA E CONSOLIDA CRITÉRIOS PARA INSCRIÇÃO DE VALORES NAS CONTAS DE CRÉDITOS EM LIQUIDAÇÃO E PROVISÃO PARA CRÉDITOS DE LIQUIDAÇÃO DUVIDOSA.

O BANCO CENTRAL DO BRASIL, NA FORMA DO ART. 9० DA LEI No 4.595, DE 31.12.64, TORNA PÚBLICO QUE O CONSELHO MONETÁRIO NACIONAL, EM SESSÃO REALIZADA EM 29.08.90, COM BASE NAS DISPOSIÇÕES DO ART. 4, INCISOS VI, XI E XII, DA CITADA LEI,

R E S O L V E U:

ART. $1^{\circ}$. DETERMINAR QUE OS BANCOS MÚLtiplos, BANCOS COMERCIAIS, BANCOS DE DESENVOLVIMENTO, BANCOS DE INVESTIMENTO, SOCIEDADES DE CRÉDITO, FINANCIAMENTO E INVESTIMENTO, SOCIEDADES DE ARRENDAMENTO MERCANTIL, SOCIEDADES CORRETORAS E SOCIEDADES DISTRIBUIDORAS DE TÍTULOS E VALORES MOBILIÁRIOS, SOCIEDADES DE CRÉDITO IMOBILIÁRIO, CAIXAS ECONÔMICAS, ASSOCIAÇÕES DE POUPANÇA E EMPRÉSTIMO E COOPERATIVAS DE CRÉDITO TRANSFIRAM PARA AS CONTAS DE CRÉDITOS EM LIQUIDAÇÃO OS SEGUINTES CRÉDITOS CONSIDERADOS DE DIFÍCIL LIQUIDAÇÃO:

I - AdiAntAmentos A DEPOSitAntes, Após DECORRIDOS 60 (SESSENTA) DIAS DA DATA DA OCORRÊNCIA;

i - adiantamentos sobre contratos de CÂMbio, APÓS DECORRIDOS 20 (VINTE) DIAS DO PRAZO PREVISTO PARA ENTREGA DE DOCUMENTOS OU APÓS DECORRIDOS 30 (TRINTA) DIAS DO PRAZO PREVISTO PARA LIQUIDAÇÃO DO CONTRATO DE CÂMBIO RESPECTIVO;

III - DECORRENTES DE OPERAÇÕES DE CÂMBIO DE IMPORTAÇÃO, LIQUIDADAS A DÉBITO DAS CONTAS "DEVEDORES DIVERSOS - PAÍS" OU "DEVEDORES POR CRÉdITOS LIQUIDADOS NO EXTERIOR", NA FORMA DA REGULAMENTAÇÃO VIGENTE, CASO O PAGAMENTO NÃO SE EFETIVE ATÉ 90 (NOVENTA) DIAS CONTADOS DO RESPECTIVO LANÇAMENTO;

IV - TITULADOS POR EMPRESAS IMPORTADORAS QUE, NA DATA PACTUADA PARA A LIQUIDAÇÃO DA OPERAÇÃO DE CÂMBIO, NÃO CONTEM COM FUndos SUficientes PARA O ACOLHIMENTO DO DÉBito EM CONTA CORRENTE, QUANDO NÃO UTILIZADA A SISTEMÁTICA REFERIDA NO ITEM ANTERIOR;

V - SAldos DEVEdoRES DE CONTAS CORRENTES DE CLIENTES, RESULtANTES DE NEGOCIAÇÃo E INTERMEDiAÇÃo DE Títulos E VA- 
LORES MOBILIÁRIOS, NÃO LIQUIDADOS NO PRAZO DE 30 (TRINTA) DIAS DA OCORRÊNCIA, SEM GARANTIAS;

VI - FINANCIAMENTOS DE VALORES MOBILIÁRIOS, NÃO LIQUIDADOS NO PRAZO DE 30 (TRINTA) DIAS DO VENCIMENTO, CUJAS GARANTIAS, A JUÍZO DAS INSTITUIÇÕES, SEJAM CONSIDERADAS INSUFICIENTES À COBERTURA DO SALDO DEVEDOR ATUALIZADO;

VII - TITULAdOS POR EMPRESAS SOB REGIME FALIMENTAR OU EM LIQUIDAÇÃO EXTRAJUDICIAL, COM OU SEM GARANTIAS;

VIII - OUtRos CRÉditos, OBSERVANDO-SE AS SEGUINTES

CONDIÇÕES :

A - VENCIDOS, HÁ MAIS DE 60 (SESSENTA) DIAS, SEM GARANTIAS;

B - VENCIDOS, HÁ MAIS DE 180 (CENTO E OITENTA) DIAS, COM GARANTIAS QUE, A JUÍZO DAS INSTITUIÇÕES OU A CRITÉRIO DO BANCO CENTRAL DO BRASIL, SEJAM CONSIDERADAS INSUFICIENTES À COBERTURA DO SALDO DEVEDOR ATUALIZADO;

C - VENCIDOS, HÁ MAIS DE 360 (TREZENTOS E SESSENTA) DIAS, COM GARANTIAS QUE, A JUÍZO DAS INSTITUIÇÕES, SEJAM CONSIDERADAS SUFICIENTES À COBERTURA DO SALDO DEVEDOR ATUALIZADO;

D - EM FAVOR DOS QUAIS TENHA SIDO EFETIVADA MEDIDA JUDICIAL, VISANDO PROTESTO OU OUTRA SEMELHANTE, EXCETUANDO-SE AS OPERAÇÕES PARCIAL OU TOTALMENTE AMPARADAS POR GARANTIAS, AS QUAIS OBSERVARÃO O CONTIDO NAS ALÍNEAS "B" E "C" ANTERIORES;

iX - outros créditos de difícil LiQUidaçÃo, QUE POSSAM SER EFETIVAMENTE COMPROVADOS PELAS INSTITUIÇÕES PERANTE O BANCO CENTRAL DO BRASIL OU A CRITÉRIO DESTE.

ART. $\quad 2^{\circ}$. OS CRÉDITOS REFERIDOS NAS ALÍNEAS "B" E "C" DO ITEM VIII DO ARTIGO ANTERIOR PODERÃO, A CRITÉRIO DAS INSTITUIÇÕES OU DO BANCO CENTRAL DO BRASIL, SER TRANSFERIDOS PARA AS CONTAS DE CRÉditOS EM LIQUIDAÇÃO, ANTES DOS PRAZOS ALI ESTABELECIDOS, DESDE QUE VENCIDOS HA MAIS DE 60 (SESSENTA) DIAS.

PARÁGRAFO ÚNICO. O BANCO CENTRAL DO BRASIL PODERÁ SOLICITAR DAS INSTITUIÇÕES, SE FOR O CASO, PARA AS OPERAÇÕES TRANSFERIDAS NA FORMA DESTE ARTIGO, JUSTIFICATIVAS QUE COMPROVEM A CONDIÇÃO DE CRÉditOS DE DIFÍCIL LIQUIDAÇÃO.

ART. $3^{\circ}$. A tRANSFERÊNCIA PARA AS CONTAS DE CRÉ- 
DITOS EM LIQUIDAÇÃO DEVERÁ SER FEITA PELA TOTALIDADE DA OPERAÇÃO, INCLUSIVE PARCELAS VINCENDAS, ABRANGENDO TODAS AS OBRIGAÇÕES DO MESMO DEVEDOR, FACULTANDO-SE A MANUTENÇÃO, EM CONTAS DE ORIGEM, DE OUTRAS OPERAÇÕES VINCENDAS, AMPARADAS POR GARANTIAS SUFICIENTES À COBERTURA DOS RESPECTIVOS SALDOS DEVEDORES ATUALIZADOS.

ART. $\quad 4^{\circ}$. AS INSTITUIÇÕES FICAM OBRIGADAS A TOMAR MEDIDAS JUDICIAIS VISANDO PENHORA, PROTESTO OU OUTRA SEMELHANTE PARA AS OPERAÇÕES OU PARCELAS VENCIDAS, DE RESPONSABILIDADE DO SETOR PRIVADO, NO PRAZO MÁXIMO DE 180 (CENTO E OITENTA) DIAS DOS RESPECTIVOS VENCIMENTOS, INDEPENDENTEMENTE DE CONTAREM OU NÃO COM GARANTIAS, ̀̀ EXCEÇÃO DE:

I - adiantamentos a depositantes E AdiAntamenTOS SOBRE CONTRATOS DE CÂMBIO, BEM COMO CRÉDITOS DECORRENTES DAS OPERAÇÕES INDICADAS NOS ITENS III E IV DO ART. $1^{\circ}$ DESTA RESOLUÇÃO, CUJO PRAZO MÁXIMO SERÁ DE 30 (TRINTA) DIAS, A CONTAR DA DATA DA INSCRIÇÃO EM CONTAS DE CRÉDITOS EM LIQUIDAÇÃO;

II - CRÉditos CUJOS SALdOS DEVEDORES ATUALIZAdOS NÃO ULTRAPASSEM O MONTANTE CORRESPONDENTE A 2.000 (DOIS MIL) BÔNUS DO TESOURO NACIONAL.

ART. $\quad 5^{\circ}$. RESPEITADAS AS CONDIÇÕES DE TRANSFERÊNCIA PARA AS CONTAS DE CRÉDITOS EM LIQUIDAÇÃO, AS OPERAÇÕES E/OU PARCELAS VENCIDAS HA MAIS DE 60 (SESSENTA) DIAS DEVERÃO SER RECLASSIFICADAs, PELO VALOR ATUALIZADO, PARA títUlO CONTÁBIL ADEQUADO, REPRESENTATIVO DE CRÉditos EM ATRASO, PELA TOTALIDADE DA OPERAÇÃO, SEGREGANDO-SE AS DE RESPONSABILIDADE DO SETOR PRIVADO E DO SETOR PÚBLICO.

PARÁGRAFO ÚNICO. A TRANSFERÊNCIA DE OPERAÇÕES PARA CONTAS DE CRÉDITOS EM ATRASO OU CRÉDITOS EM LIQUIDAÇÃO DEVERÁ SER EFETUADA NO TRANSCORRER DO SEMESTRE, TÃO LOGO OS CRÉDITOS REÚNAM CONDIÇÕES PARA TAL E NÃO APENAS POR OCASIÃO DOS BALANÇOS SEMESTRAIS.

ART. $\quad 6^{\circ}$. A PARTIR DE 02.01.91, A APROPRIAÇÃO DOS ENCARGOS SOBRE OPERAÇÕES REGISTRADAS EM CONTAS EM ATRASO OBSERVARÁ AS SEGUINTES CONDIÇÕES :

I - DURANTE O PERÍODO DE 120 (CENTO E VINTE) DIAS, CONTADOS DA DATA DA TRANSFERÊNCIA, O REGISTRO DOS ENCARGOS EM CONTAS DE RENDAS EFETIVAS, INCLUSIVE NAS OPERAÇÕES PREFIXADAS COM RENDAS AINDA NÃO APROPRIADAS INTEGRALMENTE, FICARÁ LIMITADO AO MESMO ÍNDICE UTILIZADO NO PERÍODO PARA CORREÇÃO MONETÁRIA PATRIMONIAL, LANÇANDO-SE O DIFERENCIAL, SE HOUVER, EM CONTAS DE RENDAS A APROPRIAR; 
II - APÓS O TÉRMINO DAQUELE PERÍOdo, O REGISTRO DOS ENCARGOS FAR-SE-Á EM CONTRAPARTIDA COM CONTAS DE RENDAS A APROPRIAR, INCLUSIVE QUANDO REGISTRADAS EM CONTAS DE CRÉDITOS EM LIQUIDAÇÃO;

III - AS RENDAS A APROPRIAR, PREVISTAS NOS ITENS I E II ANTERIORES, SOMENTE PODERÃO SER RECONHECIDAS COMO RECEITA EFETIVA QUANDO DO SEU RECEBIMENTO.

ART. $\quad 7^{\circ}$. TRATANDO-SE DE CRÉditOS DECORRENTES DE FINANCIAMENTOS HABITACIONAIS OU DE REPASSES DE AGÊNCIAS DE DESENVOLVIMENTO, COM PRAZO SUPERIOR A 36 (TRINTA E SEIS) MESES, ADMITE-SE A RECLASSIFICAÇÃO, PARA CRÉDITOS EM ATRASO, APENAS DAS PARCELAS VENCIDAS.

PARÁGRAFO ÚNICO. CONSIDERAM-SE REPASSES DE AGÊNCIAS DE DESENVOLVIMENTO AS OPERAÇÕES REALIZADAS NA QUALIDADE DE AGENTE FINANCEIRO REPASSADOR DE RECURSOS DE INSTITUIÇÕES E ÓRGÃOS OFICIAIS E FUNDOS FINANCEIROS E DE DESENVOLVIMENTO, COM DESTINAÇÃO ESPECÍFICA.

ART. $8^{\circ}$. AS INSTITUIÇÕES QUE, A PARTiR DE 02.01.91, RENOVAREM OPERAÇÕES DE CRÉDITO DE DIFÍCIL OU DUVIDOSA LIQUIDAÇÃO, POR COMPOSIÇÃO DE DÍVIDA, COM A INCORPORAÇÃO DOS RESPECTIVOS ENCARGOS, DEVERÃO:

I - REGISTRAR, EM RENDAS A APROPRIAR, OS ENCARGOS INCORPORADOS NO ATO DA RENOVAÇÃO OU RENEGOCIAÇÃO E OS QUE FOREM REGISTRADOS NA FORMA DO ART. 6 DESTA RESOLUÇÃO, QUE SOMENTE PODERÃO SER RECONHECIDOS COMO RENDAS EFETIVAS POR OCASIÃO DOS RESPECTIVOS RECEBIMENTOS;

II - A PARTIR DA CELEBRAÇÃO DO CONTRATO DE COMPOSIÇÃO DE DÍVIDA, AS RENDAS DEVERÃO SER APROPRIADAS EM RECEITAS EFETIVAS, OBSERVADA A PERIODICIDADE MENSAL;

PARÁGRAFO $1^{\circ}$. RELATIVAMENTE AOS CRÉDITOS BAIXADOS COMO PREJUÍZO, AS INSTITUIÇÕES DEVERÃO REGISTRAR O PRINCIPAL ATUALIZADO, DESDE A DATA DA BAIXA, EM CONTAS DE RECEITA EFETIVA, E OS RESPECTIVOS ENCARGOS, OBJETO DA COMPOSIÇÃO DE DÍVIDA, EM RENDAS A APROPRIAR, QUE SERÃO RECONHECIDOS COMO RECEITA EFETIVA, QUANDO DOS RESPECTIVOS RECEBIMENTOS;

PARÁGRAFO $2^{\circ}$. A PARTIR DA CELEBRAÇÃO DO CONTRATO MENCIONADO NO PARÁGRAFO ANTERIOR, AS RENDAS DEVERÃO SER APROPRIADAS EM RECEITAS EFETIVAS, OBSERVADA A PERIODICIDADE MENSAL. 
ART. $99^{\circ}$. EM CADA BALANCETE MENSAL OU BALANÇO SEMESTRAL, A PROVISÃO PARA CRÉDITOS DE LIQUIDAÇÃO DUVIDOSA NÃO PODERÁ SER INEERIOR AO SOMATÓRIO DECORRENTE DA APLICAÇÃO DOS PERCENTUAIS A SEGUIR MENCIONADOS, INCIDENTES SOBRE O VALOR DOS CRÉDITOS ATUALIZADOS SEGUNDO AS NORMAS CONTÁBEIS EM VIGOR, SEM PREJUÍZO DA RESPONSABILIDADE DOS ADMINISTRADORES DAS INSTITUIÇÕES PELA CONSTITUIÇÃO DE PROVISÃO EM MONTANTES SUFICIENTES PARA FAZER FACE A PERDAS PROVÁVEIS NA REALIZAÇÃO DOS CRÉDITOS:

I - 20\% (VINTE POR CENTO) SOBRE AS OPERAÇÕES AMPARADAS POR GARANTIAS QUE, A JUÍZO DAS INSTITUIÇÕES, SEJAM CONSIDERADAS SUFICIENTES À COBERTURA DO SALDO DEVEDOR ATUALIZADO, REGISTRADAS EM CONTAS EM ATRASO;

II - 50\% (CINQÜENTA POR CENTO) SOBRE AS OPERAÇÕES AMPARADAS POR GARANTIAS QUE, A JUÍZO DAS INSTITUIÇÕES OU A CRITÉRIO DO BANCO CENTRAL DO BRASIL, NÃO SEJAM CONSIDERADAS SUFICIENTES À COBERTURA DO SALDO DEVEDOR ATUALIZADO, REGISTRADAS EM CONTAS EM ATRASO;

III - $100 \%$ (CEM POR CENTO) DOS CRÉDITOS INSCRITOS EM CONTAS DE CRÉDITOS EM LIQUIDAÇÃO.

PARÁGRAFO ÚNICO. OS CRÉdITOS A SEREM COMPUTADOS NA BASE DE CÁLCULO DA PROVISÃO PARA CRÉDITOS DE LIQUIDAÇÃO DUVIDOSA SÃO OS INSCRITOS NOS SUBGRUPOS, DESDOBRAMENTOS DE SUBGRUPOS, TÍTULOS E SUBTítUlos INTEGRANTES DO PLANO CONTÁBIL DAS INSTITUIÇÕES DO SISTEMA FINANCEIRO NACIONAL - COSIF, CONSTANTES DO QUADRO ANEXO A ESTA RESOLUÇÃO, CONSIDERADOS PELO SEU VALOR PRESENTE.

ART. 10. A DIFERENÇA ENTRE O MONTANTE DA PROVISÃO, APURADO SEGUNDO AS DISPOSIÇÕES DESTA RESOLUÇÃO, E O OBTIDO NA FORMA DO ART. 9० DA RESOLUÇÃO No 1.675, DE 21.12.89, DEVERÁ SER ELIMINADA, PODENDO, OPCIONALMENTE, SER OBSERVADOS OS SEGUINTES PERCENTUAis MÍNIMOS E CUMULATIVOS, CABENDO À INSTITUIÇÃO MANTER À DISPOSIÇÃO DO BANCO CENTRAL DO BRASIL AS RESPECTIVAS PLANILHAS DE CÁLCULO E CONTROLE :

I - 4\% (QUATRO POR CENTO) EM CADA UM DOS BALANCETES DE 30.09.90 A 30.11.90;

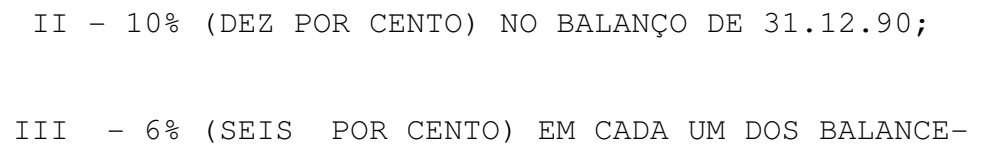


IV - 12\% (DOZE POR CENTO) NO BALANÇO DE 31.12.91.

PARÁGRAFO ÚNICO. AS INSTITUIÇÕES QUE SE UTILIZAREM DA FACULDADE PREVISTA NESTE ARTIGO DEVERÃO INSERIR NOTA EXPLICATIVA NAS DEMONSTRAÇÕES FINANCEIRAS PUBLICADAS, ESCLARECENDO OS CRITÉRIOS ADOTADOS PARA CONSTITUIÇÃO DA PROVISÃO, INCLUSIVE FAZENDO REFERÊNCIA ÀS DIFERENÇAS A SEREM ELIMINADAS.

ART. 11. OBSERVADAS AS CONDIÇÕES ABAIXO, PODERÃO SER DEBITADOS À PROVISÃO OS CRÉDITOS:

I - VENCIDOS, QUE NÃO TENHAM CONDIÇÕES DE RECEBIMENTO, APÓS DECORRIDOS, NO MÍNIMO, 180 (CENTO E OITENTA) DIAS DA DATA DE TRANSFERÊNCIA PARA AS CONTAS DE CRÉDITOS EM LIQUIDAÇÃO; OU

II - AJUIZAdOS, APÓS ESGOtAdOS OS MEIOS USUAis E NORMAIS DE COBRANÇA JUDICIAL; OU

III - CUJOS SALDOS DEVEDORES ATUALIZADOS NÃO ULTRAPASSEM O MONTANTE CORRESPONDENTE A 2.000 (DOIS MIL) BÔNUS DO TESOURO NACIONAL, APÓS DECORRIDOS 180 (CENTO E OITENTA) DIAS DOS RESPECTIVOS VENCIMENTOS.

ART. 12. ENTENDEM-SE COMO COBERTAS POR GARANTIAS AS OPERAÇÕES AMPARADAS POR:

I - CAUÇÃO DE DUPlicAtas Vincendas E ACEitas, ASSIM CONSIDERADAS, TAMBÉM, AQUELAS REMETIDAS AOS SACADOS E QUE NÃO TENHAM SIDO OBJETO DE CONTESTAÇÃO, OU DE QUAISQUER OUTROS DIREITOS DE CRÉditos RESUltantes dE VENDAS DE MERCADORIAS OU DE PRESTAÇÃO DE SERVIÇOS, DESDE QUE TAIS TÍTULOS NÃO SEJAM DE EMISSÃO OU ACEITE DE EMPRESAS LIGADAS AO FINANCIADO;

II - CAUÇÃO DE TÍtUlos DE EMISSÃo, ACEITE OU COOBRIGAÇÃO DE INSTITUIÇÕES FINANCEIRAS NÃO LIGADAS AO CREDOR E QUE NÃO SE ENCONTREM EM REGIME ESPECIAL (LEI No 6.024, DE 13.03.74), BEM COMO DE TÍtUlos ADMITIdos NO SISTEMA ESPECIAL DE LIQUIDAÇÃO E DE CUSTÓDIA - SELIC;

III - CAUÇÃO DE AÇÕES NEGOCIADAS EM BOLSAS DE VALORES E DE DEBÊNTURES REGISTRADAS NA COMISSÃO DE VALORES MOBILIÁRIOS, ESTAS DE EMISSÃO DE EMPRESAS NÃO LIGADAS, DIRETA OU INDIRETAMENTE, AO CREDOR/DEVEDOR, SENDO QUE AS NOMINATIVAS DEVERÃO ESTAR REGISTRADAS NO LIVRO DE AÇÕES NOMINATIVAS E AS ESCRITURAIS NA RESPECTIVA ENTIDADE DEPOSITANTE/CUSTODIANTE; 
IV - CAUÇÃO dE DOCUMENTOS REPRESEntAtivos de DEPÓSITOS DE MERCADORIAS DE FÁCIL VENDA NO MERCADO E NÃO PERECÍVEIS ("WARRANT"), COM JUNTADA DO RESPECTIVO CONHECIMENTO DE DEPÓSITO E LAUDO DESCRITIVO RESULTANTE DE FISCALIZAÇÃO REALIZADA HÁ MENOS DE 90 (NOVENTA) DIAS;

$\mathrm{V}$ - FIANÇA BANCÁRIA, NACIONAL OU ESTRANGEIRA, DESDE QUE PRESTADA POR INSTITUIÇÃO DEVIDAMENTE HABILITADA, QUE NÃO SEJA LIGADA AO DEVEDOR;

VI - HIPOTECA DE IMÓVEL, RESPEITADO QUALQUER DIREITO DE PREFERÊNCIA DE OUTROS CREDORES;

VII - PENHOR INDUSTRIAL E MERCANTIL, REGULARMENTE CONSTITUÍDO, COM OBSERVÂNCIA DE TODAS AS FORMALIDADES LEGAIS APLICÁVEIS, CUJOS BENS PENHORADOS ESTEJAM PERFEITAMENTE IDENTIFICADOS E CARACTERIZADOS, INCLUSIVE COBERTOS POR SEGURO;

VIII - ALIENAÇÃO FIDUCIÁRIA, REVESTIDA DE TODAS AS FORMALIDADES LEGAIS PREVISTAS NO ART. 66 DA LEI No 4.728, DE 11.07.65, ALterado PELO ART. 10 DO DECRETO-LEI No 911, DE 01.10.69;

IX - CAUÇÃO OU CESSÃO DE DIREITOS CREDITÓRIOS REFERENTES AO FUNDO DE PARTICIPAÇÃO DOS ESTADOS E DO DISTRITO FEDERAL E FUNDO DE PARTICIPAÇÃO DOS MUNICÍPIOS, DESDE QUE CONSTE, DO INSTRUMENTO CONTRATUAL, EXPRESSA INTERVENIÊNCIA DO BANCO DO BRASIL S.A., QUE RECEBERÁ CONFIRMAÇÃO IRREVOGÁVEL PARA RETER E REPASSAR AO CREDOR AS COTAS PARTES CORRESPONDENTES DAQUELES FUNDOS;

$X$ - CAUÇÃO, AUTORIZADA POR LEI, DE ICMS A SER RECOLHIDO, DESDE QUE CONSTE, DO INSTRUMENTO CONTRATUAL, EXPRESSA INTERVENIENNCIA DO AGENTE FINANCEIRO ESTADUAL RESPECTIVO PARA RETER E REPASSAR AO CREDOR AS COTAS PARTES CORRESPONDENTES DAQUELE TRIBUTO;

XI - APÓLICE DE SEgURO DE CRÉdito DE EXPORTAÇÃO, EM NOME DA ENTIDADE BENEFICIÁRIA, SATISFEITAS AS CONDIÇÕES PREVISTAS NAQUELE DOCUMENTO;

XII - BENS ARRENDAdOS, DECORRENTES DE CONTRATOS DE ARRENDAMENTO MERCANTIL;

XIII - AVAL DE TERCEIROS QUE, COMPROVADAMENTE, DISPONHAM DE BENS QUE POSSAM SER OBJETO DE ARRESTO OU PENHORA EM VALOR SUFICIENTE À COBERTURA DO SALDO DEVEDOR ATUALIZADO.

PARÁGRAFO $1^{\circ}$. NA HIPÓTESE DE GARANTIA REPRESENTA- 
DA POR HIPOTECA, SERÁ EXIGIDO QUE:

A - A PROPRIEDADE DO RESPECTIVO IMÓVEL SEJA CERTIFICADA POR ESCRITURA DEFINITIVA, INSCRITA NO CARTÓRIO DE REGISTRO DE IMÓVEIS ;

B - O IMÓVEL CONTE COM LAUdO DE AVALIAÇÃO ELABORAdO POR PERITO OU EMPRESA, CUJO NOME TENHA SIDO APROVADO FORMALMENTE EM REUNIÃO DA DIRETORIA OU DO CONSELHO DE ADMINISTRAÇÃO, NÃO SE ADMITINDO A SIMPLES CORREÇÃO MONETÁRIA DE VALOR APURADO EM AVALIAÇÃO ANTERIOR, SE PROMOVIDA HÁ MAIS DE 360 (TREZENTOS E SESSENTA) DIAS;

C - NO CASO DE O LAUDO TER SIDO FIRMADO POR EMPRESA LIGADA OU SETOR ESPECIALIZADO DA PRÓPRIA INSTITUIÇÃO CREDORA - OBEDECIDAS AS CONDICIONANTES DO PARÁGRAFO $2^{\circ}$ DO ART. 8० DA LEI Nº 6.404, DE 15.12.76 - ESTA FIQUE RESPONSÁVEL PELA SUA FIDEDIGNIDADE, PARA TODOS OS EFEITOS LEGAIS, INCLUSIVE COM VISTAS AO DISPOSTO NO ART. 44, ITEM I E PARÁGRAFO 1\%, DA LEI No 4.595, DE 31.12.64;

D - SEJA FEITA INSCRIÇÃO DA HIPOTECA NO CARTÓRIO DE REGISTRO DE IMÓVEIS; E

E - QUANDO SE tRATAR DE BENFEItORIAS, ESTAS DEVEM SER COBERTAS POR SEGURO, COM CLÁUSULA EM FAVOR DA INSTITUIÇÃO CREDORA, EXCETO QUANDO OS IMÓVEIS ESTEJAM LOCALIZADOS EM ÁREA RURAL.

PARÁGRAFO $2^{\circ}$. A ANÁLISE DA INSTITUIÇÃO, PARA EFEITO DA CLASSIFICAÇÃO DAS GARANTIAS, DEVERÁ SER FEITA PERIODICAMENTE, EM PRAZOS NÃO SUPERIORES A 360 (TREZENTOS E SESSENTA) DIAS, ATRAVÉS DE LAUDO, QUE PODERÁ SER ELABORADO POR SETOR ESPECIALIZADO DA PRÓPRIA INSTITUIÇÃO, ADMITINDO-SE, NOS INTERVALOS, AJUSTE POR CORREÇÃO MONETÁRIA.

PARÁGRAFO $3^{\circ}$. NO CASO DE OPERAÇÕES RELATIVAS A FINANCIAMENTOS HABITACIONAIS, GARANTIDAS POR HIPOTECAS DE IMÓVEIS, COBERTAS POR SEGURO DE CRÉDITO, FICARÁ A CRITÉRIO DAS INSTITUIÇÕES A PERIODICIDADE ADEQUADA À ELABORAÇÃO DO LAUDO DE AVALIAÇÃO, EM PRAZOS NÃO SUPERIORES A 720 (SETECENTOS E VINTE) DIAS.

ART. 13. AS INSTITUIÇÕES MANTERÃO REGISTROS ANALÍTICOS COM INFORMAÇÕES COMPLETAS SOBRE OS CRÉDITOS DE LIQUIDAÇÃO DUVIDOSA, INCLUSIVE COM TODOS OS ELEMENTOS QUE PERMITAM A ADEQUADA AVALIAÇÃO DO VALOR PROVÁVEL DE REALIZAÇÃO, OS QUAIS FICARÃO À DISPOSIÇÃO DO BANCO CENTRAL DO BRASIL E DO AUDITOR INDEPENDENTE. 


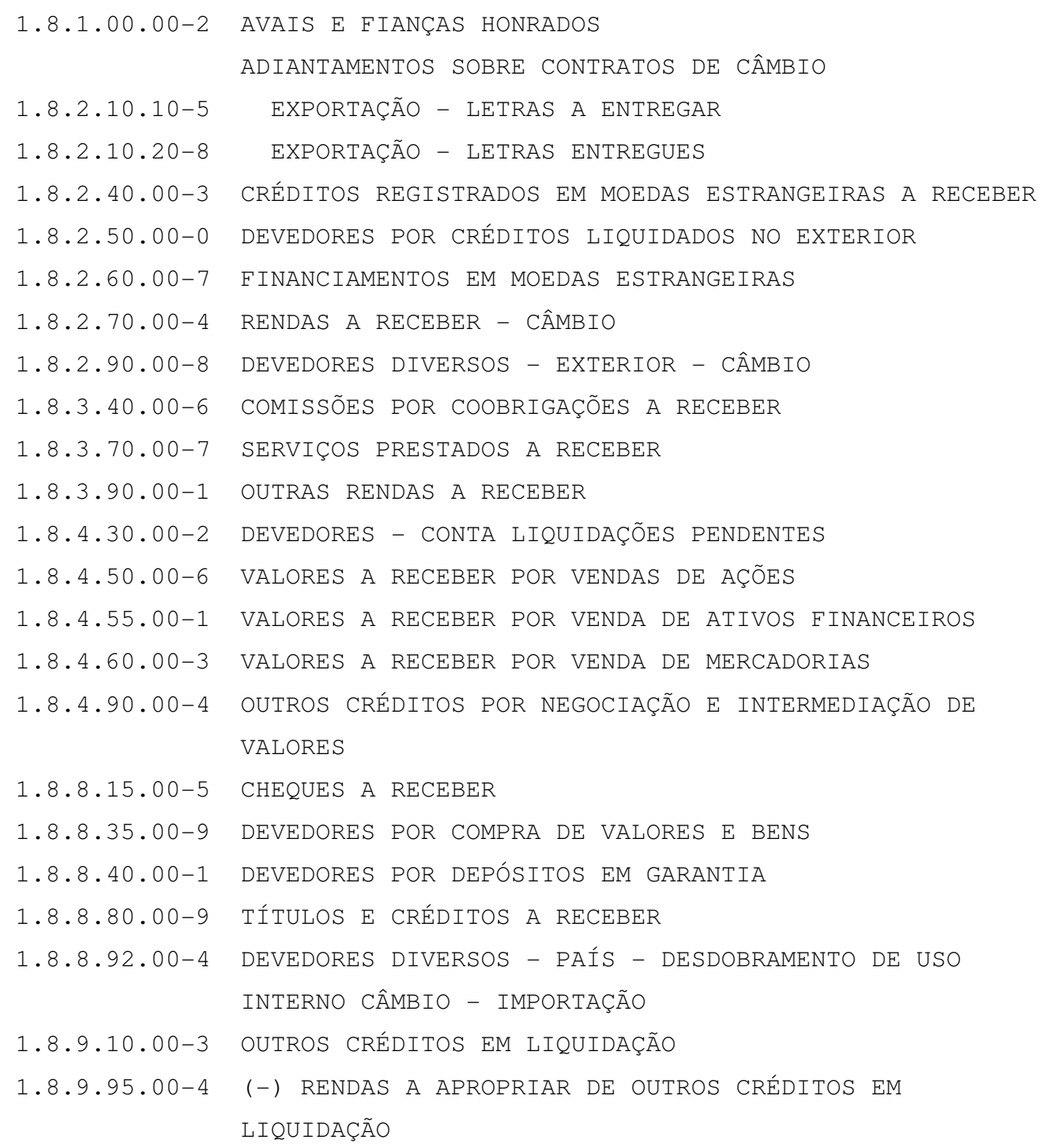




\section{ANEXO C - CARTA DE CONFORTO E SIGILO}

São Paulo, xx de xxxxx de 2007.

\section{CARTA DE CONFORTO E SIGILO}

Prezados Senhores,

Pela presente Carta de Conforto e Sigilo, o pesquisador Marco Antonio Guimarães Verrone, aluno do curso de Mestrado em Administração na Faculdade de Economia, Administração e Contabilidade da Universidade de São Paulo, orientando do Prof. Dr. Wadico Waldir Bucchi, agradece por sua contribuição à sua Dissertação de Mestrado, intitulada Basiléia II no Brasil: Uma Reflexão com Foco na Regulação Bancária para Risco de Crédito - Resolução CMN 2.682/99 e compromete-se a manter sigilo sobre as informações e dados obtidos mediante entrevista, destacando-se especialmente:

- Não identificar nominalmente os entrevistados, na dissertação ou em qualquer outro documento;

- Não associar especificamente, de modo direto ou indireto, quaisquer das suas respostas e informações à instituição financeira em que atua;

- Não fazer uso das informações obtidas, de nenhuma maneira, nem a qualquer tempo, que não seja para fins exclusivamente acadêmicos.

Atenciosamente,

Marco Antonio Guimarães Verrone

Ciente:

Prof.Dr.Wadico Waldir Bucchi 